01ok 04/05/2011 8:34 Página 9

ENCUESTA 
01ok 04/05/2011 8:34 Página 10 


\section{ENCUESTA SOBRE LA SENTENCIA DEL TRIBUNAL CONSTITUCIONAL 31/2010, DE 28 DE JUNIO (ESTATUTO DE AUTONOMÍA DE CATALUÑA)}

\section{PRESENTACIÓN}

Es un lugar común señalar que una de las tareas más complejas a la que trataron de dar respuesta los constituyentes fue la descentralización del poder. Más allá del establecimiento de ciertos límites, lo cierto es que en nuestra Carta Magna se produjo una cierta desconstitucionalización del modelo de Estado o compromiso apócrifo del poder constituyente. Ello no sólo supuso situar al Tribunal Constitucional en una posición central en el proceso de construcción del Estado Autonómico, sino que ha impulsado al poder constituido a ingeniar mecanismos de desarrollo de este Estado Autonómico, algunos de dudoso ensamblaje constitucional. Quizá ello explique, al menos en parte, lo especialmente controvertido del proceso abierto por el Título VIII de la Constitución.

Tal vez esa sea la causa de que nuestra Revista, Teoría y Realidad Constitucional, que siempre ha querido estar abierta a una visión dialéctica del constitucionalismo, abriendo sus páginas a toda suerte de debates, haya prestado especial atención en sus tradicionales encuestas al proceso de descentralización territorial.

Ya en el tercer volumen, que vio la luz el primer semestre de 1999, se quiso realizar una primera aproximación a la dinámica del sistema autonómico. Desde la perspectiva que ofrecían los ya entonces veinte años largos de vigencia de nuestra Carta Magna, se pidió en esta sección a ilustres catedráticos de la asignatura que se pronunciaran sobre este proceso, acerca de su desarrollo y de las posibilidades de futuro. La encuesta se centró en analizar el propio Título VIII de la Constitución y su proceso de desarrollo, que ya había presentado importantes momentos conflictivos, pero que también había propiciado no menos trascendentales acuerdos entre fuerzas políticas.

En cualquier caso, las iniciativas adoptadas en la legislatura pasada de reforma de los Estatutos de Autonomía, que parecían ahondar en una la dinámica ínsita al principio federal, provocaron no sólo un fuerte debate académico y doctrinal, sino también una no menor desafección entre fuerzas políticas. Surgían serias dudas sobre si el nuevo proceso iniciado vulneraba o no concretos preceptos constitucionales, pretendiendo una reforma encubierta de la propia Constitución al margen de los previstos en el Título X; aunque también se cuestionó, más allá de las posibles infracciones singulares, si estas reformas, aún cabiendo dentro de la generosa apertura en la materia que caracteriza a nuestra Ley 
Fundamental, suponían un cambio sustancial del vigente modelo de distribución territorial del poder y consecuentemente de la forma territorial del Estado.

El número 24 de Teoría y Realidad Constitucional así también su encuesta a analizar el nuevo proceso iniciado, planteando tanto una valoración general del proceso como un análisis específico de la única resolución del Tribunal Constitucional recaída hasta el momento, la STC sobre el Estatuto de Valencia. En cualquier caso, ya se apuntaba entonces en la última pregunta de aquella encuesta la especial trascendencia que había de tener la resolución del supremo intérprete constitucional sobre el Estatuto de Cataluña. Ello, porque esta reforma fue la que causó mayor polémica, y parecía ir en muchos casos más allá de los límites que marca nuestra Constitución hecho que provocó consiguientemente varios recursos ante el Tribunal Constitucional.

La reciente sentencia del alto tribunal sobre el particular supone un punto de inflexión en el proceso. El supremo intérprete constitucional, que no único, colocado en una situación más que conflictiva, se ha pronunciado finalmente sentando con ello las bases de una nueva forma de entender el orden territorial español, anulando ciertos preceptos del Estatuto, pero aceptando la constitucionalidad de otros muchos mediante la consabida fórmula de la interpretación conforme. A juicio del Consejo de Redacción de esta Revista el alto valor que tiene esta sentencia bien merece volver a dedicar una encuesta para su análisis. Para ello se ha invitado a catedráticos y especialistas del tema que ya se habían pronunciado en las encuestas antes referidas donde las cuestiones planteadas a la luz de esta importante resolución sean en el fondo una excusa para volver a plasmar libremente sus ideas sobre el particular.

\section{CUESTIONES}

1. Como introducción, ¿Quiere hacer alguna consideración sobre la posición en que se ha encontrado, en su sentencia 31/210, de 28 de junio, el Tribunal Constitucional, máximo guardián de la supremacía jurídica de la Constitución, y sobre el contexto de los cuatro años que ha necesitado para sentenciar? Sabido es que el TC ba debido entender de unos recursos interpuestos por el PP, el Defensor del Pueblo y órganos de diversas CCAA, una vez producidos los pronunciamientos del Parlament, de las Cortes Generales y de la ciudadanía catalana en referéndum sobre El Estatut; y así mismo, tras un amplio desarrollo legislativo del mismo mediante legislación autonómica. ¿Cómo valora estas circunstancias? ¿Entendería pertinente modificar la LOTC para prever recursos previos de inconstitucionalidad respecto de proyectos de Estatutos de Autonomía?

2. ¿Qué nos desea decir sobre el valor que la Sentencia a que nos referimos otorga al preámbulo del Estatuto, a la mención del mismo a que se habia concebido a Cataluña por el Parlament como «Nación» y sobre otros puntos conexos?

3. ¿Nos puede emitir su opinión sobre los pronunciamientos de esta Sentencia acerca de la cooficialidad lingüística?

4. Respecto de la doctrina y los pronunciamientos en el fallo, que contiene la Sentencia sobre la actuación de órganos institucionales del Estado en Cataluña o de nuevos órganos de la Comunidad de Cataluña, como el denominado "Consejo de Justicia de Cataluña", o sobre la participación de la Generalitat en órganos e instituciones estatales ¿qué reflexiones quiere bacernos? 
5. El tratamiento, ciertamente extenso, que la Sentencia dedica a las llamadas cuestiones competenciales, ¿Qué comentarios le suscita a Vd.?

6. ¿La doctrina y los pronunciamientos de esta Sentencia del TC respecto de los contenidos estatutarios en materia de financiación, qué opinión le merecen en su condición de constitucionalista?

7. ¿En la medida en que considere viable emitir una opinión de conjunto, ¿podría sintetizar los aspectos, a su juicio, más afortunados de la Sentencia del alto Tribunal que nos ocupa y los que babrían sido mejorables?

8. ¿Nos puede dar alguna opinión sobre los puntos que $V d$. desee glosar de todos o de algunos de los votos particulares?

\section{ENCUESTADOS}

Roberto Blanco Valdés. Catedrático de Derecho Constitucional de la Universidad de Santiago de Compostela

Raúl Canosa Usera. Catedrático de Derecho Constitucional de la Universidad Complutense de Madrid

Francesc de Carreras Serra. Catedrático de Derecho Constitucional de la Universidad Autónoma de Barcelona

Marc Carrillo López. Catedrático de Derecho Constitucional de la Universidad Pompeu Fabra

Javier Corcuera Atienza. Catedrático de Derecho Constitucional de la Universidad del País Vasco

Javier García Roca. Catedrático de Derecho Constitucional de la Universidad Complutense de Madrid

Luciano Parejo Alonso. Catedrático de Derecho Administrativo de la Universidad Carlos III de Madrid 


\section{RESPUESTAS}

1. Como introducción, ¿Quiere hacer alguna consideración sobre la posición en que se ba encontrado, en su sentencia 31/210, de 28 de junio, el Tribunal Constitucional, máximo guardián de la supremacía jurídica de la Constitución, y sobre el contexto de los cuatro años que ba necesitado para sentenciar? Sabido es que el TC ha debido entender de unos recursos interpuestos por el PP, el Defensor del Pueblo y órganos de diversas CCAA, una vez producidos los pronunciamientos del Parlament, de las Cortes Generales y de la ciudadanía catalana en referéndum sobre El Estatut; y así mismo, tras un amplio desarrollo legislativo del mismo mediante legislación autonómica. ¿Cómo valora estas circunstancias? ¿Entendería pertinente modificar la LOTC para prever recursos previos de inconstitucionalidad respecto de proyectos de Estatutos de Autonomía?

\section{ROBERTO BLANCO VALDÉS}

Mi primera consideración al respecto se referirá al hecho de que todas los antecedentes aludidos (peculiar naturaleza de la norma estatutaria catalana como consecuencia de su ratificación en referéndum; inadmisible retraso en la decisión del TC; desarrollo legislativo de la norma impugnada, en gran medida como consecuencia de tal retraso en sentenciar) creo que determinaron el contenido del pronunciamiento del Tribunal en relación con el recurso presentado por el Partido Popular, pronunciamiento que resulta incomprensible sin tener a la vista las circunstancias que se mencionan en la pregunta y otra más, sobreañadida, y, en gran medida, consecuencia del larguísimo tiempo transcurrido entre la presentación de las impugnaciones y la resolución 31/2010: que el Tribunal fue objeto de presiones crecientes, que acabaron por condicionar con toda claridad su libre capacidad de decisión. Esas presiones procedieron, en un primer momento, tanto del partido que había impugnado el Estatuto como de las fuerzas que lo habían apoyado en Cataluña y en las Cortes Generales y se dirigieron a lograr que el TC dictase una Sentencia lo más favorable posible a las pretensiones de unos o de otros: la traducción fundamental de esa primera fase de presiones, que no hubieran dado el resultado buscado si el Tribunal se hubiese negado a entrar en el juego al que se le incitaba desde fuera, se concretó en la presentación de diversas recusaciones de magistrados, una de las cuales, como es sabido, sería aceptada finalmente. Pero tras esa primera fase de presiones cruzadas y contradictorias, se abrió una segunda, después de que pudiera constatarse, por medio de constantes filtraciones de las deliberaciones del TC, que aquel no confirmaría en su totalidad la constitucionalidad del Estatuto, tal y como pretendían sus impulsores. Esta segunda fase, en la que las presiones públicas procedieron casi exclusivamente de los sectores que habían apoyado el Estatuto y que dio lugar a pronunciamientos políticos e incluso institucionales que desafiaban con toda claridad la autoridad y autonomía del TC, se basó en la supuesta teoría de que, dada la naturaleza de la norma (aprobada por dos parlamentos de forma sucesiva y ratificada luego en referéndum) el alto Tribunal no tenía otra posibilidad que limitarse a confirmar la plena constitucionalidad del Estatuto, pues cualquier otra decisión entraría — se afirmaba- jurídicamente en contradicción con el grado de legitimidad de la norma impugnada, supondría una flagrante violación del 
principio democrático y constituiría, en conclusión, una irresponsable contribución al deterioro de las relaciones entre Cataluña y España (es decir, el resto de España). Como trataré de explicar más adelante, todas esas presiones, y de manera muy especial las últimas a las que acabo de referirme, tendrían a la postre una clara traducción en el texto de la Sentencia 31/2010, en la que es apreciable un grado de deferencia hacia el legislador que, en mi opinión, resultaría de otro modo incomprensible.

\section{Raúl Canosa Usera}

Nada encontramos en ese contexto de cuatro años de demora en resolver los recursos contra el Estatuto de Cataluña que sea ejemplar; ni las exorbitantes recusaciones ni la prórroga indebida del mandato de algunos magistrados ni, sobre todo, las tensiones sufridas por el TC. Aquello que debió resolverse entre los partidos políticos ha acabado ventilándose en el Alto Tribunal, y cualquiera que hubiera sido su decisión, ésta habría generado polémica extraordinaria. En mi opinión, pues, no ha sido el TC ni mucho menos el causante principal del entuerto sino el empecinamiento de los partidos políticos en no resolver un conflicto creado por ellos. Con todo, la STC 31/2010 sirve para despejar algunas dudas y también habría de inspirar modificaciones de la misma Constitución o en otras leyes que evitarán desafueros en el futuro. En este sentido convendría acaso reintroducir el recurso previo de inconstitucionalidad contra estatutos de autonomía, de tal suerte que ni se confrontara la legitimidad del TC para enjuiciarlos con la legitimidad de aquellos ya aprobados por las Cortes Generales e incluso refrendados ni pudiera un Estatuto pendiente de enjuiciamiento constitucional, producir efectos y ser desarrollado infraestatutariamente.

Por lo demás, carece de sentido que un Estatuto, al socaire de su «función constitucional», pueda ser aprobado como simple ley orgánica con la pretensión de fijar, con carácter general, el sentido de conceptos y categorías constitucionales a despecho del poder de reforma constitucional y del máximo intérprete de la Constitución. Si esto pudiera, la mayoría necesaria para su aprobación habría de ser mayor que la requerida para aprobar leyes orgánicas. De lo contrario, la «convención constitucional» que ha permitido aprobar todos los Estatutos y sus reformas con una mayoría superior en cuya integración participaban todas las fuerzas políticas relevantes, podría romperse como sucedió en el caso del último Estatuto de Cataluña. La STC 31/2010, que no podía sugerir una ampliación de esas mayorías, ha acabado por ignorar lo dicho en la STC 247/2007 y si bien reconoce las posibilidades de los Estatutos para «delimitar»o «describir» competencias, ha negado que puedan definirlas, reservando esta función al poder de reforma o al intérprete supremo de la Constitución.

Al margen de las mayorías requeridas para su aprobación o del momento idóneo para efectuar el control de constitucionalidad, un Estatuto, cuyo ámbito de validez se circunscribe a una parte del territorio del Estado, no es idóneo para definir conceptos y categorías constitucionales abiertas, pues si lo hiciera se crearían asimetrías, no sólo competenciales, que destruirían la coherencia del sistema, incluso si este fuera inequívocamente federal. Tales asimetrías habrían de recogerse en el texto constitucional (valga como ejemplo la disposición adicional primera de la Constitución). Si 
como afirmó el TC en su sentencia sobre la LOAPA, una ley Estado no podía cerrar la apertura constitucional en materia de descentralización, tampoco pueden hacerlo los Estatutos.

\section{FranCESC DE CARreras SERra}

Esta pregunta es muy pertinente para entender el significado de la sentencia ya que el crédito del Tribunal Constitucional ha sufrido el más grave desgaste ante la opinión pública debido a lo que ha sucedido desde que se interpusieron los recursos contra el Estatuto hasta que se hizo pública la sentencia. Sin duda este descrédito ha influido en el debate interno del Tribunal. En todo ello, una parte de la responsabilidad es del propio Tribunal pero, sobre todo, los más responsables son los partidos políticos y, en menor medida, los medios de comunicación.

La primera causa por la cual son responsables los partidos políticos — por supuesto, en este punto, sólo aquellos apoyaron el Estatuto en el Parlamento de Cataluña, en el Congreso y en el Senado - fue la de aprobar una ley con tantas dudas de constitucionalidad, semánticamente tan ambiguo, en una materia tan emocionalmente delicada, sabiendo, además, que debía ser aprobado por referéndum en Cataluña y, sin duda algunas, muchos de sus preceptos serían objeto de recurso o cuestión de inconstitucionalidad ante el TC. Si durante los años en que se gestó el proyecto en Cataluña ya dieron la medida de su conflictividad, la imprudencia al aprobarlo fue de carácter temerario.

Esta responsabilidad es todavía mayor para los socialistas catalanes y para el PSOE. Los primeros lo impulsaron en Cataluña para atraerse como aliados a ERC y alcanzar, como así fue, la presidencia de la Generalitat. El PSOE lo apoyó en las Cortes Generales para obtener el apoyo de CiU en el Congreso y asegurar así su mayoría gubernamental. Por tanto, ambos partidos actuaron por exclusivas causas de interés partidista táctico inmediato sin calcular que, en el medio y largo plazo, el Estatuto catalán les crearía graves problemas, como así ha sido.

Por el contrario, la posición de los partidos nacionalistas catalanes, ERC y CiU, es más coherente porque el proceso estatutario responde a sus intereses a medio y largo plazo. ERC se sitúa a sí misma fuera del sistema constitucional al declararse independentista; uno de sus objetivos obvios es desestabilizar el Estado de las autonomías y con el proceso estatutario — desde los comienzos hasta la sentencia - lo ha conseguido. CiU esconde su auténtica finalidad declarándose soberanista, un confuso término, pero buena parte de su dirección y de sus militantes coinciden con los objetivos de ERC. Si CiU se adhirió a finales del año 2002 al PSC y a ERC en la carrera hacia el nuevo estatuto fue debido a que este último partido le estaba sustrayendo centenares de miles de votos si no se subía a este carro. Ciertamente, la mayoría de sus militantes y una parte de sus votantes no hubieran entendido que se desaprovechara tal oportunidad.

Hasta esta ocasión, las grandes opciones sobre el rumbo del Estado autonómico se habían adoptado por acuerdo de los dos grandes partidos estatales (UCD y PSOE en 1981 y PSOE y PP en 1992). Cualquier pacto de este género, con voluntad de ser durable y sólido, debe tener como firmantes a los dos grandes partidos, representantes del $80 \%$ de los votantes. Lo inexplicable, por su obvia insensatez, es que uno de estos parti- 
dos —en este caso el PSOE - pretenda llevar a cabo una reforma importante en materia territorial pactando con formaciones como ERC y CiU que no son autonomistas sino que se autodefinen como independentistas o soberanistas. El fatal desenlace estaba anunciado, pues, desde el comienzo mismo.

La segunda responsabilidad de los partidos afecta a su comportamiento tras la aprobación del Estatuto. Es verdad que hay que agradecer al PP la interposición rápida del recurso de inconstitucionalidad, así como al Defensor del Pueblo y a los demás órganos de las comunidades autónomas que también los presentaron. Sin su resuelta actitud la organización territorial del Estado habría entrado por una senda de total confusión. Sin embargo, creo que el PP se equivocó gravemente recusando, a mi parecer de forma infundada, al magistrado Pérez Tremps, con lo cual se inició una cascada de otras recusaciones aún menos fundadas - por parte del PSOE, de la Generalitat y del mismo PPa distintos magistrados, entre ellos la misma presidenta del Tribunal. La imagen de politización del TC cundió rápidamente ante la opinión pública, alimentada por unos medios de comunicación que, frívolamente, se prestaron a dividir al TC en dos sectores irreconciliables, conservadores y progresistas, ambos sometidos a la obediencia de los partidos que les habían propuesto para el cargo, algo que a la postre, tras la sentencia, se ha visto que no era cierto.

Así, una institución jurisdiccional independiente e imparcial, como es el TC, pasó a ser considerada como un órgano político partidista, un ámbito en el cual los partidos proseguían sus disputas políticas utilizando como instrumento al Derecho. Pero el mal estaba hecho y era irremediable. La situación empeoró cuando el grupo socialista del Congreso introdujo una enmienda en la LOTC que aseguraba la prórroga de la presidencia del TC hasta que el titular terminara su mandato como magistrado, algo que es contrario a la literalidad del último inciso del art. 160 CE. Recurrida esta reforma, el mismo Tribunal la declaró, con una débil argumentación, conforme a la Constitución. Todo ello parecía confirmar que el Gobierno tenía interés en asegurar la permanencia en su cargo de la actual presidenta hasta que se hubiera dictado la sentencia, con lo cual, ante la opinión pública, la señalaba como persona adicta al Gobierno y, por tanto, escasamente independiente e imparcial. Curiosamente, ha sido esta presidenta quien, como ponente, ha desatascado finalmente el largo y maldito embrollo con una sentencia que considera inconstitucionales, por una u otra vía, preceptos estatutarios clave del estatuto y hace que renazca tímidamente la confianza en la independencia de los magistrados, sean quiénes sean los partidos que los hayan propuesto.

Para completar el cuadro de las responsabilidades de los políticos hay que hacer un capítulo aparte con los catalanes. Su actitud a la espera de la sentencia puede ser descrita a través de tres fases sucesivas. La primera fue de confianza: esperaban una sentencia favorable ya que no dudaban que una mayoría de magistrados del TC — los llamados progresistas- estaban de su lado. Era un cálculo meramente político, por supuesto desconocedor de lo que debe ser un juez y de su obligada independencia de criterio, siempre un criterio fundado en Derecho, nunca en razones de conveniencia u oportunidad políticas. En esta fase lo único que se recriminaba al Tribunal era su lentitud en dictar la sentencia.

La segunda fase empezó en julio de 2009, justo después que se filtrara en el diario «El País» un borrador de sentencia, acordada por la mayoría progresista —así lo señala- 
ba el rotativo- - en el que se declaraban nulos, o se formulaban reparos de inconstitucionalidad, a una cuarentena de preceptos. Saltaron todas las alarmas y entonces comenzó una larga batalla en Cataluña de desgaste del Tribunal. Desde los partidos y, muy especialmente, desde el Gobierno de la Generalitat se logró movilizar a lo que en Cataluña se denomina «sociedad civil», un conjunto de instituciones, asociaciones, empresas y personalidades, siempre obedientes al poder, sea cual sea, ya que de él obtienen numerosos beneficios. El argumento más socorrido fue que el Estatuto era un pacto político y, como tal, no podía ser objeto de control jurídico. Argumento peregrino sólo superado por aquel otro según el cual el Estatuto expresa sentimientos y los sentimientos no pueden ser juzgados por un Tribunal. Y también se recurría a un tercer argumento, el del miedo: una sentencia contraria al Estatuto, se decía, iba a aumentar la supuesta distancia que separa a Cataluña de España. En otras palabras, que el independentismo crecería si la sentencia era negativa. Debe señalarse que todos estos argumentos fueron utilizados durante toda la segunda parte del año 2009 y hasta bien entrado el 2010 por los más altos representantes de la Generalitat, en concreto por el presidente Montilla. Por este motivo, fueron recogidos en la prensa y secundados por influyentes columnistas, además de suscritos en manifiestos de adhesión por asociaciones, empresarios, sindicatos, colegios profesionales, universidades y otras entidades e instituciones de muy diverso tipo.

La tercera fase comienza a finales de abril, cuando parecía que la sentencia era ya inminente: fue la fase de la desesperación ante lo que ya se contemplaba como inevitable. En lugar de optar por la serenidad se optó por la inmadurez y la poca inteligencia: así puestos, de perdidos al río. Se llegó al ridículo jurídico: el Parlamento y el Gobierno catalanes se dirigieron al Tribunal instándole a que se declarara incompetente para dictar la sentencia. Nadie jurídicamente informado podía confiar en que esta argucia prosperara. Lo que se pretendía, simplemente, era retrasar la sentencia hasta después de las elecciones catalanas por temor a sus repercusiones políticas. Pero el ridículo alcanzó también a otras instituciones, entre ellas las universidades. Ya hemos aludido a que unos meses antes los rectores habían firmado un documento apoyando la constitucionalidad del Estatuto. Ahora también los decanos de todas las facultades de Derecho de Cataluña fueron instrumentalizados y a tal fin elaboraron un documento - y lo pasaron a la firma de los demás profesores - en el cual expresaban su convencimiento de que el Estatuto era conforme a la Constitución, sin dar razón alguna para ello y, además, indicando a los magistrados el sentido de la resolución que debían tomar. En un insólito último párrafo, llegaron a invertir la relación entre una parte procesal y el juez al sostener que, en caso de que se declararan inconstitucionales elementos esenciales del Estatuto, el pacto político que éste expresaba «quedaría situado fuera de la Constitución», deslizando, a renglón seguido, la velada amenaza de que «los riesgos generados por esta situación no pueden escapar a nadie». Tal razonamiento, incomprensible en personas que, en principio, deben saber en qué consiste un Estado de Derecho, era el desesperado último intento del Gobierno de la Generalitat para retrasar la sentencia.

Por último, en este capítulo de responsabilidades no pueden quedar excluidos los propios magistrados del Tribunal, con su presidenta al frente, por el retraso en dictar sentencia. No es cierto que el Tribunal tardara cuatro años, como se dice, porque el estudio de la misma se inició en enero de 2008, tras aprobar en el diciembre anterior la STC 247/2007 sobre el Estatuto de la Comunidad Valenciana. Por tanto, el TC ha empleado 
dos años y medio en el debate, con frecuentes interrupciones debidas a otras sentencias urgentes y a la aplicación de algunos complejos aspectos de la reforma de 2007 de la LOTC, como es por ejemplo la doctrina sobre el concepto de «especial trascendencia constitucional» para la admisión de los recursos de amparo. Además, nunca en una ley, ni de lejos, se habían impugnado tantos preceptos. La dificultad en resolver una sentencia como la del Estatuto equivale — en cantidad y calidad — a la resolución de decenas de otras sentencias en recursos de inconstitucionalidad.

Todo ello es cierto. Ahora bien, en julio de 2009 la sentencia estaba más que deliberada, no había más argumentos a debatir y lo único que faltaba era adoptar una decisión... que no llegó hasta un año después. Este período de pudrimiento y de inactividad —incluso, a partir de finales de 2009, casi no llegaron a aprobarse sentencias en otros procedimientos - es lo que hay que reprocharle al Tribunal, además de ofrecer la sensación, imposible de probar, que algunos magistrados no han resistir a presiones externas de carácter político. Está mal que los políticos no respeten la independencia judicial con sus presiones pero todavía es peor que los magistrados no sepan resistir a las mismas. Además, también hay que hacer mención de las muy frecuentes filtraciones a los periódicos, con lo cual en algunos momentos se tenía la sensación que se trataba de un debate retransmitido interesadamente, sin prueba de veracidad alguna, por los medios de comunicación. Ahí la presidenta hubiera debido poner orden y abrir expedientes para hacer las averiguaciones pertinentes. No lo hizo y el crédito del Tribunal siguió decreciendo.

En conclusión, ni políticos ni magistrados — aunque ni todos los políticos, ni todos los magistrados - estuvieron a la altura de las circunstancias sino todo lo contrario. La resolución final, en cambio, es una sentencia en general bien razonada, concisa, clara y basada en argumentos fundados, sobre todo con el apoyo de la propia doctrina del Tribunal y, por tanto, una sentencia previsible, sin ninguna contaminación política apreciable como demuestra el hecho que haya disgustado profundamente a los partidos favorables al Estatuto, en especial a los partidos catalanes.

Por último, una respuesta breve a la última cuestión que se formula en la pregunta: si sería conveniente restablecer el recurso previo de inconstitucionalidad.

No se puede dudar de la legitimidad del Tribunal para resolver recursos de inconstitucionalidad interpuestos contra estatutos ratificados por referéndum y no hacen falta grandes razonamientos para justificarlo: los estatutos son normas con rango de ley sometidos a la Constitución como reconoce, sin hacer excepciones, el art. 27 LOTC. Ahora bien, por razones políticas, es decir, de oportunidad y conveniencia, resultaría adecuado restablecer, sólo para estos casos en que medie referéndum, el recurso previo de inconstitucionalidad, un procedimiento no extraño en nuestro ordenamiento puesto que ya está previsto para los tratados internacionales. Este recurso debería poder ser interpuesto una vez que el estatuto hubiera sido aprobado por las Cortes Generales y antes de ser sometido a la ratificación popular. Ahora bien, dicho esto — que puede llevarse a cabo con facilidad dado que, simplemente, basta con modificar la LOTC — cabría una solución mejor, aunque políticamente algo difícil: que ningún estatuto requiera del referéndum para ser aprobado. Los referendos de ratificación de normas son métodos que deben reservarse sólo para casos muy excepcionales, normalmente para normas con aspectos muy simbólicos como puede ser una Constitución que suponga la inauguración de un nuevo 
régimen político. Lo normal en democracia es que las leyes se aprueben por mayoría, en ciertos casos es razonable que lo sean por mayorías reforzadas, pero el referéndum es un método extraordinario - y muy deficientemente democrático- que debe reservarse para ocasiones singulares por razones justificadas. No creo que las reformas estatutarias entren en estos supuestos. No tiene sentido, además, que la mayor parte de los artículos de nuestra Constitución puedan reformarse sin que el referéndum sea imprescindible y, en cambio, que algunos estatutos lo requieran para reformar uno solo de sus preceptos.

\section{Marc CARrillo López}

El recurso de inconstitucionalidad presentado por diputados del PP contra el Estatuto de autonomía de Cataluña, ha supuesto que por primera vez el Tribunal Constitucional se pronuncie sobre la práctica integridad de un Estatuto. Si a ello se añade el recurso presentado por el Defensor del Pueblo que, a su vez, cuestionaba buena parte de la reforma estatutaria y los recursos presentados por diversas CCAA (Aragón, Murcia, La Rioja, la Comunidad Valenciana e Islas Baleares), que discrepaban de la constitucionalidad de aspectos más puntuales, no cabe duda que al Tribunal se le planteaba una tarea no fácil y de gran importancia jurisdiccional.

Una tarea, asimismo, también de relevancia institucional, porque con la reforma estatutaria catalana, se incorporaba un nuevo Estatuto que por razón de su contenido más amplio y diverso que el anterior (incorporación de un título de derechos, nueva configuración de las competencias, concreción de la financiación, determinación de los instrumentos de relación con el Estado y la UE, etc.), suponía un reto jurídico de amplio calado al Tribunal. Y a este reto no ha respondido. Por las razones que argumento en las preguntas siguientes de esta encuesta, el Tribunal se ha atenido instrumentalmente a parte de su jurisprudencia anterior, sin que el cambio que supone la reforma estatutaria en el bloque de la constitucionalidad aplicable a la Generalidad de Cataluña, haya servido como acicate para, en su caso, incorporar a la jurisprudencia sobre la distribución del poder territorial nuevos criterios que, en el marco de la Constitución, permitiesen afrontar la modificación del parámetro de constitucionalidad que suponía la reforma del Estatuto, en su condición de norma complementaria de la Constitución, como así lo reconocía la STC 247/2007, relativa al Estatuto de la Comunidad Valenciana.

Pero el Tribunal ha respondido con una sentencia en la que la fundamentación jurídica no se caracteriza por su extensión, sino más bien por su carácter apodíctico, en la que parte de su jurisprudencia hasta ahora creada es concebida como un código inmutable para la interpretación del Estado de las autonomías. Y ello en demérito de la relevancia normativa del Estatuto como norma institucional básica de la Comunidad Autónoma. Una sentencia, de la que sorprende que en su fundamentación no aparezca consideración alguna acerca del referéndum al que, conforme al procedimiento prescrito por la Constitución, fue sometido el proyecto de reforma. Sobre todo por si, en su caso, esta legitimación democrática adicional pudiera haber sido también tenida en cuenta por el Tribunal Constitucional en el juicio de constitucionalidad sobre el Estatuto. Al no haber sido así, siempre habrán razones para preguntarse si, desde la primacía de la Constitución como norma, por qué el Tribunal no tuvo también en cuenta en algún momento de su 
importante decisión, el criterio de deferencia hacia el Parlamento de Cataluña y las Cortes Generales, a fin de afrontar con la mayor ponderación posible el juicio de constitucionalidad sobre la obra del legislador democrático.

A lo largo de los cuatro años transcurridos hasta llegar a la sentencia, la situación interna del Tribunal no ha coadyuvado a la resolución del recurso ponderada en Derecho. En este sentido, un desafortunado ejemplo lo constituyó, por su insostenible doctrina en la jurisdicción constitucional, la recusación del magistrado Pablo Pérez Tremps, que fue apartado del caso por la realización de un trabajo académico anterior a adquirir la condición de magistrado, analizando un informe realizado por académicos previo al proyecto de reforma estatutaria. Este dislate jurisdiccional avaló la iniciativa promovida extramuros del Tribunal con finalidades espurias y supuso un lastre a su labor posterior. A lo que hay que añadir la sucesión cruzada de posteriores recusaciones de magistrados por supuestas noticias de prensa. O la irregular situación —imputable a la inacción del Senado- de cuatro magistrados que votaron la sentencia con un mandato agotado más de tres años. Todo lo cual, adobado con algún que otro insólito episodio acerca de la relación de algún miembro del Tribunal con los medios de comunicación, en ejercicio del derecho reconocido en la Ley Orgánica 2/1984, de 26 de marzo, reguladora del derecho de rectificación, no ha servido precisamente para reforzar la legitimidad de ejercicio de la jurisdicción constitucional, en otro tiempo la joya de la corona de las instituciones democráticas españolas.

Tampoco ha ayudado en el ámbito jurídico, que preceptos idénticos de otros estatutos reformados a lo previsto en el Estatuto de Cataluña, no hayan sido objeto de recurso de inconstitucionalidad. Lo cual plantea la cuestión la controversia sobre la eficacia de las leyes que han desarrollado dichos estatutos y aquellas otras que ha desplegado el Estatuto catalán que ya han sido recurridas, cuando en ambos casos el precepto estatutario habilitante era el mismo o similar..

Desde el ámbito político, por supuesto, no hay duda que los diversos avatares acontecidos no han sido precisamente, una buena compañía en el largo proceso transcurrido hasta la STC 31/2010. La cultura republicana del aprecio y respeto por las instituciones públicas y el interés general se ha mostrado especialmente ausente, una circunstancia ésta que pone de relieve un alarmante grado de déficit de calidad democrática del sistema político español.

Un comentario específico merece el uso hecho por el Defensor del Pueblo de su legitimación para recurrir leyes aprobadas por las Cortes Generales (art. 162.1, b CE) y, en este caso, para recurrir buena parte del contenido del Estatuto. Ciertamente, en ningún momento la Constitución limita o condiciona el ejercicio para recurrir en inconstitucionalidad lo que sin duda ha sido un quebradero de cabeza para el Defensor del Pueblo ${ }^{1}$. Pero no hay que olvidar que el objeto de su función, como magistratura de persuasión, es fijado por la la Constitución en la «defensa de los derechos comprendidos en este Título (el Título I), a cuyo efecto podrá supervisar la actividad de la Administración...». En este sentido, es bien sabido que desde el primer momento la institución del Defensor decidió delimitar u

1 Vid. A.GIL-Robles y Gil-Delgado, «Articulo 54»; en: Comentarios a la Constitución Española. XXX Aniversario (Drs. Ma Emilia CASAS BAAMONDE y M. RoDRíGUEZ PIÑERO y BRAVO FERRER). Fundación Wloters Kluwer. Madrid 2009, p. 1197. 
orientar el ejercicio de su legitimación para plantear el recurso de inconstitucionalidad respecto de aquellas leyes que a su juicio pudiesen vulnerar los derechos y libertades reconocidos en la Constitución. Sin embargo, en el caso del Estatuto catalán este comportamiento procesal no se ha seguido. Cuando hubiese sido coherente con lo hasta ahora realizado con carácter general, que el Defensor hubiese recurrido aspectos relativos al Título I del Estatuto relativo a los derechos estatutarios o — como así lo ha hecho- el precepto relacionado con las competencias del Sindic de Greuges (art. 78 EAC). Por el contrario, no lo ha sido que recurriese una buena parte del resto del texto que ya forma parte de los derechos y libertades reconocidos por la Constitución, alterando el sentido y el alcance material del art. 54 de la Constitución.

Finalmente, en relación a la conveniencia de recuperar el control previo de constitucionalidad sobre los proyectos de Estatutos, que ya propugnó el Informe del Consejo de Estado de 16 de febrero de 2006, no me parece que sea una solución pertinente. La propuesta formulada por el alto órgano consultivo del Gobierno establecía que en los proyectos de reforma estatutaria en los que se dilucide la constitucionalidad de cuestiones de contenido competencial, el control previo de constitucionalidad debería llevarse a cabo una vez aprobado el texto por las Cortes Generales. A mi juicio ésta no es una solución que exima al Tribunal Constitucional de quedar expuesto a la controversia política que pueda derivarse de una reforma estatutaria. Aunque evite el plus de la legitimación democrática adicional derivada del referéndum, en los que casos que éste venga exigido por la Constitución. No hay que olvidar, en este sentido, que las razones que aconsejaron la supresión del recurso previo se fundaban en el uso más político que no jurídico que la oposición había hecho de este instrumento procesal-constitucional para, sobre todo, retardar o dificultar la aprobación de las iniciativas políticas de la mayoría. Si ello era así con respecto a los proyectos de leyes orgánicas, nada excluye que con los Estatutos pudiese ocurrir tanto de lo mismo o probablemente más. El caso del Estatuto catalán ha sido un buen y nada edificante ejemplo. Por esta razón, tratándose el Estatuto de una norma que es resultado de la concurrencia de la voluntad de dos parlamentos que, por cierto, llevó a la STC 247/2007 a sostener la naturaleza paccionada de la norma institucional básica (lo que, todo sea dicho, es ignorado en la STC 31/2010), no parece que el restablecimiento del control previo ayudase a evitar la implicación más directamente política del Tribunal. A reserva de una reforma constitucional que, de acuerdo con el modelo autonomía política previsto en la Constitución, evaluase la procedencia de que la aprobación de los Estatutos aprobados a referéndum, fuesen susceptibles de ser recurridos ante la jurisdicción constitucional, mientras tanto, no sería partidario de modificar la regulación actual.

\section{Javier Corcuera Atienza}

Alguna consideración sobre la posición en que se ha encontrado el TC y sobre el contexto de los cuatro años que ha necesitado para sentenciar?...:

Desde el momento de la gestación del Estatut casi todo fue desmesura. Se empezó optando por un texto de máximos impulsado por el deseo de conseguir aspiraciones quizá históricas, pero no fácilmente alcanzables por la vía de la reforma estatutaria. Y menos en 
el momento en que se propuso. Era previsible que el Partido Popular ganara las elecciones generales de 2004, y era notoria su oposición a cualquier reforma en materia autonómica, cuánto más a modificaciones de tanto calado como las que se pretendían. El texto no nacía para ser aprobado, sino para levantar la bandera de lo que se deseaba y, subsidiariamente, para desautorizar políticamente a quien lo impedía.

Pero el resultado de los comicios fue diferente al esperado. A partir de entonces, las relaciones entre los dos grandes partidos fueron de hostilidad incesante, que progresivamente fue manifestándose en todas las esferas de la vida pública. Lamentablemente, también en la actividad del Tribunal Constitucional, que hasta el momento había cumplido muy dignamente sus funciones, sin verse afectado por la bipolarización sectaria que ya había llegado al Consejo General del Poder Judicial. El debate sobre la constitucionalidad se planteaba menos en el terreno del Derecho que en el de la descalificación política, bien del Gobierno que lo había apoyado, bien de la oposición que lo impugnaba.

Los dioses ciegan a quienes quieren perder. Empezó una carrera por conseguir la recusación de magistrados cuyo planteamiento se consideraba definido; la prensa informaba en base a las posturas de «conservadores» o "progresistas», dejando traslucir que lo que importaba no era la interpretación jurídica de un texto, sino las lealtades políticas; filtraciones, que sólo podían proceder del propio Tribunal, daban cuenta de informaciones internas, con el único interés aparente de incidir en el resultado de las deliberaciones... Cabe pensar que no era ese un marco apropiado para la búsqueda de consensos, y la decisión de no elegir al sucesor de un magistrado fallecido, o la de retrasar indefinidamente la renovación de los miembros que debía elegir el Senado, parecía confirmar la dificultad de plantear en el terreno del Derecho algo que se movía en el aparentemente exclusivo terreno de la política.

¿Hubiera sido positiva la existencia de un recurso previo de inconstitucionalidad para los proyectos de Estatutos de Autonomía? Hay cosas que la mejor ley no puede arreglar. Nada permite imaginar que el recurso previo hubiera conseguido dar a luz una sentencia en un plazo menor al de los cuatro años que ha costado nacer a ésta, y quizá hubiera sido mayor el conflicto si se hubiera producido un retraso en tales circunstancias. Por otra parte, la experiencia del sistema de control previo en el caso de leyes orgánicas y Estatutos de autonomía no tuvo efectos especialmente brillantes. Sirvió, sobre todo, para trasladar al Tribunal la resolución de problemas que hubieran de haberse consensuado en las Cortes, dilatando innecesariamente su puesta en marcha y corriendo el riesgo de convertir al TC en una tercera cámara. Esa ha sido la fuente de los problemas que comentamos: no debe intentarse una reforma de tanta entidad como la del modelo autonómico sin el amplio consenso que permitió las reformas posteriores a los Pactos Autonómicos de 1981 o 1992. Y ello es más importante si se tiene en cuenta que, al margen de desmesuras, había razones en 2004 que aconsejaban abordar la reforma del modelo.

\section{JAVIER GARCÍA RoCA}

Son varias preguntas. Comenzaré por la posición del Tribunal Constitucional en la división de poderes como intérprete supremo de la Constitución y guardián de la supremacía de sus normas. La sentencia que nos ocupa suscita el dilema del alcance de esta 
función, dado el amplio entendimiento que el propio Tribunal ha concedido a su tarea y a su intersección con las funciones constitucionales de los Estatutos dentro del llamado «bloque de la constitucionalidad». Esa atípica y estructuralmente inestable Constitución abierta española. Este es el problema central. Se trata de dos tareas conceptualmente diversas, pero con evidentes intersecciones a la hora de concretizar la Constitución, sus lindes no son claras y no estoy seguro de que en este conflicto se hayan delimitado con fronteras inamovibles, por más que se hayan precisado las lógicas limitaciones de cualquier bilateralidad estatutaria.

El Tribunal Constitucional recuerda que los Estatutos son normas subordinadas a la Constitución y no expresión de un poder soberano, y que se integran en el ordenamiento jurídico bajo la forma específica de un tipo de ley estatal, la ley orgánica, forma jurídica a la que se reserva su aprobación y reforma (artículos 81.1 y 147.3 CE); de aquí se deduce tajantemente que «su posición en el sistema de fuentes es... la característica de las leyes orgánicas» y que se relacionan con otras leyes conforme al principio de competencia y con la Constitución según el de jerarquía (STC 31/2010, de 28 de junio, FF.JJ. $1^{\circ}$ a $7^{\circ}$ ).

Estimo que la conclusión es demasiado asertiva, sostener que la posición de los Estatutos es la de las leyes orgánicas, porque el Tribunal no se molesta en razonar sobre ninguno de los argumentos clásicos aparecidos en el largo y bien conocido debate doctrinal sobre estas fuentes del Derecho. No se ponderan ciertos rasgos que dan una naturaleza muy específica a esta fuente: los Estatutos son Estatutos y, probablemente, normas constitucionales secundarias como ha defendido Rubio. Enunciemos esas especificidades. La base decisional más amplia de los Estatutos frente a las simples leyes orgánicas, fruto del triple acuerdo de voluntades de varios sujetos: el Parlamento autonómico proponente, las Cortes Generales y el cuerpo electoral en referéndum; siendo la diferente base decisional un ingrediente de toda jerarquía. Un muy especial procedimiento de aprobación en el caso de las Comunidades Autónomas del artículo 151 CE, donde es de subrayar la atípica capacidad de enmienda de las Cortes mediante motivos de desacuerdo, técnica que parece buscar el compromiso. Su integración en el bloque de la constitucionalidad (artículo 28.2 LOTC), cerrando los espacios abiertos en las normas constitucionales mediante una interpretación auténtica. El fuerte principio de indisponibilidad de los Estatutos frente a todo tipo de leyes incluidas las orgánicas. La dificultad de un deslinde material con otras leyes estatales basado en el principio de competencia. No encuentro razonamiento alguno en la sentencia sobre estos argumentos, de manera que la decisión puede calificarse de asertiva en cuanto simplificadora de la complejidad del asunto. Ojalá sea acertada, pero la argumentación, por parca y elemental, no es plenamente suasoria.

Más adelante el Tribunal reconoce también que los Estatutos cumplen funciones constitucionales, pero no entrecruza ambas afirmaciones (F.J. $4^{\circ}$ ) ni extrae consecuencias y éste creo que es uno de los puntos más débiles de la sentencia. Se dice que los Estatutos diversifican el ordenamiento mediante la creación de sistemas autonómicos de los cuales son la norma institucional básica, que son también garantía de indemnidad pero sólo por remisión de la Constitución misma, y, en tercer lugar, que tienen una función de atribución de competencias a las Comunidad Autónoma, «pero eso no hace al Estatuto una norma atributiva de competencia al Estado». Las competencias estatales son siempre continúa la sentencia - de origen constitucional a diferencia de las autonómicas que vienen determinadas en los Estatutos. Ahora bien «no pocas de las de las competencias es- 
tatales vienen mediatamente determinadas por los Estatutos, si bien únicamente en el sí y en el quantum». Afirmación que se aclara añadiendo. En lo primero, porque algunas competencias sólo serán del Estado en la medida en que no las hayan asumido las Comunidades Autónomas. En lo segundo, porque el alcance de la competencia estatal puede ser mínimo o superior, dependiendo de los términos en que se produzca la asunción estatutaria.

Esta comprensión de las funciones de los Estatutos como normas atributivas de competencias me parece apropiada. El alcance de las competencias del Estado no se puede fijar bilateralmente y de forma distinta — puede que hasta contradictoria - en 17 Estatutos, debe por ello ser objeto de una regulación multilateral. Pero insistiré en que el Tribunal no entrecruza la explicación de tales importantes funciones constitucionales, que no cumplen otras leyes orgánicas, con su afirmación de que su naturaleza sea la de simples leyes orgánicas. Concluyamos que son unas leyes orgánicas bastante distintas de las otras.

Estas dos importantes afirmaciones se completan en la sentencia con una tercera (F.J. $\left.6^{\circ}\right)$. El contenido posible de los Estatutos tiene un doble límite, uno de orden cuantitativo, referido al grado de densidad normativa aceptable para no petrificar el ordenamiento, que configura una objeción de mera oportunidad o técnica normativa. Y otro de orden cualitativo, derivado de la diferencia entre poder constituyente y poderes constituidos en especial, y referido a la regulación de las categorías y conceptos constitucionales, entre ellos la definición de la competencia de la competencia que como acto de soberanía corresponde a la Constitución, es inaccesible a cualquier legislador «y está sólo al alcance de la función interpretativa del Tribunal Constitucional» (con cita de la STC 76/1983, de 5 de agosto, sobre el proyecto de LOAPA).

En resumen, el Tribunal Constitucional se otorga a si mismo un robustecido papel en su función de intérprete supremo de la Constitución, diríase que se echa sobre sus espaldas la carga de concretizar prácticamente toda esta Constitución tan abierta. Una tarea ciclópea, que ojalá pueda cumplir, al menos mientras no recuperemos la capacidad de compromiso, y se reforme la Constitución territorial para cerrarla y actualizarla.

De forma complementaria, la sentencia limita el papel de los Estatutos en el «bloque de la constitucionalidad», ya que no pueden definir conceptos ni categorías constitucionales; obsérvese que, a diferencia de en muchas otras ocasiones en tres décadas de jurisprudencia, casi ni se menciona esa expresión. Cabe pensar que ante el entendimiento demasiado expansivo del bloque en el Estatut, se responde en la sentencia con otra comprensión restrictiva en exceso: los Estatutos no son más que leyes orgánicas que atribuyen competencias a las Comunidades Autónomas. Posiblemente en el término medio esté la virtud y desde luego mi posición personal: los Estatutos pueden interpretar una Constitución abierta, pero eso sí en todo lo que no sea multilateral, pues su función está en establecer la relación específica de una Comunidad con el Estado.

Sentada esta cuestión central, es preciso remarcar que es la primera vez que se impugnó todo un Estatuto de Autonomía. La larga demanda discutía prácticamente todas las disposiciones, aunque no se llevaran bastantes de las tachas de inconstitucionalidad al petitum. Ausente un amplio doble consenso de las fuerzas políticas en ambas Cámaras y convertido el Estatuto en un terreno de lucha, el Tribunal Constitucional se ha visto obligado a asumir una tarea garantista compleja y desmedida para lo que no es más que una 
«jurisdicción», y no un poder de reforma constitucional. Ello haría injusta cualquier tentativa de imputarle demasiadas responsabilidades, mediante críticas excesivas, al asumir como pudo la solución de un conflicto político demasiado intenso. Esta enorme tarea no debió corresponderle íntegramente de haber asumido previamente de forma adecuada sus funciones otros órganos del Estado que, a impulsos de la dirección elegida por los partidos políticos, no parece que actuaran con la diligencia debida. Es preciso explicitarlo con el distanciamiento propio del análisis constitucional - lejos de cualquier ira y con voluntad de integración constitucional - para afrontar una autocrítica colectiva, y por si la reflexión sobre este episodio nacional contribuyera de algún modo a que la desdichada experiencia no volviera a producirse. La pérdida de un amplio consenso en políticas territoriales impide funcionar con una Constitución tan abierta como la nuestra. Esta es la primera evidente pero consistente lección del conflicto: sólo mediante acuerdos autonómicos sucesivos puede desarrollarse el impreciso y ambiguo Título VIII, repleto de compromisos dilatorios.

En efecto, las Cortes Generales no fueron muy rigurosas en la aprobación de la propuesta, asumiendo con rigor el ejercicio pleno de la función legislativa ${ }^{2}$ que la Constitución les concede en vez de contentarse con la ratificación o modificaciones parciales. Se limitaron a menudo a impulsar al Tribunal Constitucional a redactar una sentencia interpretativa mediante el añadido, en las disposiciones estatutarias, de cláusulas de reenvío a otras leyes estatales, lo que no deja de ser una curiosa forma de legislar, algo así como pasar a otro órgano constitucional una patata caliente... Una suerte de «legislación por invitación al intérprete supremo» de la Constitución, que resultaba hasta entonces desconocida, al menos con la misma intensidad, y que no debería reiterarse. Algunos parlamentarios que tras la sentencia critican abiertamente el Estatuto, sólo lo censuraron fuera de las cámaras y lo aprobaron con su voto sin presentar enmiendas ni abrir debates de constitucionalidad.

Con antelación, el Parlamento de Cataluña debió asegurarse con mayor prudencia de la plena adecuación a la Constitución de su propuesta, respetando la vinculación positiva a la Constitución que es obligada para todos los poderes públicos ex art. 9.1 CE. En vez de emprender una demasiado arriesgada «ingeniería constitucional», sin demasiadas seguridades ni cautelas, probablemente queriendo autoconvencerse las fuerzas políticas que aprobaron el Estatuto del valor de un soporte doctrinal que habían encargado al Instituto de Estudios Autonómicos y fue elaborado durante años. El punto de partida fue claro: ante la imposibilidad política de reformar la Constitución, por la falta de mayoría en la Cortes, se quiso hacer desde Cataluña una lectura diferente de la misma en el bloque de la constitucionalidad mediante una reforma estatutaria, dada la existencia, en cambio, de una mayoría en el Parlamento catalán. Todo ello con la doble voluntad política, en primer lugar, de llevar la descentralización y el autogobierno al máximo po-

2 Esta era una de las conclusiones generales del dictamen — en la parte publicada - sobre la propuesta de reforma del Estatuto de Cataluña, de 24 de octubre de 2005, que, tras el benévolo dictamen del Consejo Consultivo de la Generalidad, elaboramos F. Balaguer, J. García Roca, M. Medina y A. Saiz Arnaiz, pág. 9 , «es deseable que las Cortes Generales realicen en el texto de la propuesta las modificaciones necesarias para adecuar el contenido de esos preceptos necesitados de interpretación, para aclarar sus enunciados y adaptarlos con rigor a lo dispuesto en la Constitución, despejando así cualquier duda sobre su constitucionalidad». 
sible, siempre hasta la frontera, forzando al límite donde fuera menester la constitucionalidad de las normas; y, en segundo, de blindar la autonomía catalana frente a las leyes del Estado. La idea básica consistía, por tanto, en hacer del Estatuto una garantía de indemnidad, el llamado «blindaje competencial», que protegiera de manera reforzada el autogobierno, asumiendo el riesgo de erigirlo en una fuente muy transversal que invadiera el lugar de otras fuentes y las desplazara. La apuesta era muy osada.

Tal filosofía finalmente se ha revelado imposible después de la sentencia. Nuestra Constitución es estructuralmente abierta a los Estatutos, pero también a las leyes del Estado que delimiten competencias, como acertadamente reconoce el artículo 28.2 de la LOTC, construyendo una idea de constitucionalidad mediata y explicitando la noción de «bloque de la constitucionalidad». Ese es su rasgo indefectible o esencial nos guste o no. Y un Estatuto, que no es ejercicio de un poder constituyente, no puede abrogar la jurisprudencia constitucional, como en varios extremos se intentaba, tentativa que el Tribunal Constitucional no ha aceptado.

Claro está, la Constitución se reforma únicamente mediante los procedimientos dispuestos en el Título X. Pero la cuestión es bastante más complicada, pues son varios los instrumentos de transformación que permiten su paulatina adecuación a las nuevas realidades, entre ellos, la doctrina que el Tribunal cree como intérprete supremo y las reformas estatutarias sobrevenidas dentro de dicho bloque; de ambas cosas tenemos suficientes experiencias en treinta años. Sin embargo, el conflicto del Estatut permite decantar un límite cierto a estas transformaciones: no cabe hacer una «mutación» global de la Constitución de todo el Estado en un único Estatuto. Recordemos que el sabio Georg Jellinek ya nos advirtió de que las normas de la Constitución federal a veces se transforman en su entendimiento y alcance en las Constituciones de los Estados, y no sólo a través de la reforma constitucional de sus disposiciones escritas; y que su discípulo Hsü Dau Lin insistió en que la mutación constitucional es sobre todo un problema específico del Estado federal, observando que el reparto y el desplazamiento de competencias con los Estados miembros ofrecen oportunidades muy frecuentes para este fenómeno. Ahora bien, las mutaciones constitucionales en el Estatut tenían una excesiva entidad, cualitativa y cuantitativa, invadían otras no menos constitucionales reservas (LOFCA, LOPJ, etc.), y, sobre todo, se topaban con fronteras derivadas de la lógica de la multilateralidad, imprescindible en la organización de cualquier Estado ordenamiento e inherente a la «competencia de competencias». La mutación era a veces excesiva, topaba con la literalidad de algunas normas constitucionales y olvidaba que la específica relación de una Comunidad con el Estado no puede imponerse al resto de las Comunidades.

Por último, sorprende la benévola actuación del entonces Consejo Consultivo de Cataluña en su dictamen 269, de 1 de septiembre de 2005, quien no percibió excesivos reparos de constitucionalidad en sus funciones de control interno dentro del procedimiento legislativo cuando fue preguntado por la Mesa. Pese a que es verdad que estimó la inconstitucionalidad de bastantes preceptos de la proposición de ley orgánica y que salvó la constitucionalidad de otros muchos únicamente si se interpretaban de cierta manera. Pero, de otro lado, incluso uno de los Votos particulares discutió que fuera procesalmente posible la revisión de la constitucionalidad de la propuesta de reforma del Estatuto. 
Creo, en suma, que el segundo problema ha sido la sucesiva pérdida del lugar de cada órgano en la división de poderes ante una propuesta de Estatuto excesiva en su afán de transformar la lectura de la Constitución desde el bloque de la constitucionalidad, pero que, por otro lado, afrontaba con voluntad reformista deficiencias estructurales de nuestro modelo, que, en su mayor parte, tras la sentencia siguen existiendo y que ahora sólo podrá resolver la reforma de la Constitución. No me parece pueda bastar con la labor del intérprete supremo.

Un tercer problema deriva tanto del retraso de la sentencia, toda justicia retrasada es una justicia denegada, como del serio daño causado a la imagen o apariencia de imparcialidad del Tribunal Constitucional. Si bien es una mera variante del anterior, el desplazamiento del lugar de cada uno de los poderes públicos y de las instituciones en la división de poderes, un principio cuyo respeto caracteriza a todo verdadero constitucionalismo.

La decisión llega tras cuatro años de aplicación del Estatuto. Después de sorprendentes y constantes filtraciones en la prensa sobre el sentido de la deliberación y los alineamientos de los Magistrados. Y cuando diversos desarrollos legales (v.gr. la modificación de la LOFCA) y Decretos de traspaso ya habían sido aprobados y algunas controversias competenciales afrontadas (por ejemplo, la regulación del permiso de trabajo respecto de los extranjeros según el artículo 138.3 EAC, o la nueva reordenación de la inspección nacional de trabajo que el artículo 170.2 EAC reclama).

Se ha tardado un tiempo injustificado, por excesivo, en dictar sentencia, que no se ha invertido únicamente en el estudio de los problemas jurídicos sino que es consecuencia de las tremendas presiones políticas proyectadas sobre los Magistrados constitucionales, unas tensiones que han dificultado alcanzar acuerdos jurídicos mediante el diálogo y la deliberación, e incluso han llevado hasta intentar alterar la composición predeterminada de dicho órgano constitucional. No creo exagerar.

Reseñemos la anómala situación en que se puso sentencia. Primero, cuatro de los Magistrados estaban — según se decía— «en funciones», y, en realidad, indebida e inconstitucionalmente prorrogados al hacerse de su limitada provisionalidad, por el Senado que debió renovarlos, una imposible permanencia. Es una contradicción en sustancia llamar «prórroga» a un período supuestamente suplementario y que se prolonga durante nada menos que tres años fuera del plazo, un tercio del mandato, incumpliendo la norma constitucional sobre la duración máxima del cargo, y haciendo inviable la necesaria renovación tempestiva y escalonada (artículo 159.3 CE). Un incumplimiento fundado en un artificioso subterfugio legal, constitutivo de un manifiesto rodeo o fraude a la Constitución, ya que la exégesis que se hace del artículo 17.2 de la LOTC, en éste y en otros casos, exorbita el propio fin de la norma y la erige en una regla alternativa a la constitucional. Se permite indebidamente renovar a los Magistrados constitucionales cuando caprichosa y arbitrariamente los partidos deseen, en vez de comprender que la ley orgánica configura una muy lógica, pero medida, excepción al mandato constitucional, necesariamente muy limitada en su duración. El desproporcionado y prolongado incumplimiento de los plazos constitucionales hace inconstitucional una prórroga que no puede dilatarse indefinidamente; nada autoriza a pensar que las normas temporales, en cuanto variante de las formales o procedimentales, sean menos supremas y constitucionales que las materiales y, en definitiva, menos vinculantes para los órganos constitucionales y los partidos que impulsan su actuación. Tal es la dimensión del desatino. Se- 
gundo, un Magistrado falleció sin ser tampoco sustituido, de nuevo, para no alterar la proporción de los votos. Y, tercero, otro Magistrado fue recusado de manera no menos indebida, lo que provocó la insólita reacción de una cuarentena de Catedráticos de Derecho Constitucional quienes advirtieron razonadamente por escrito (publicado en los medios el 10 de febrero de 2007) que no podía recusarse como Magistrado a un jurista de notorio prestigio simplemente por mantener sus previas y reiteradas opiniones doctrinales como experto, si no queremos estar irremediablemente destinados a tener un Tribunal Constitucional compuesto por ilustres desconocidos.

La obsoleta aplicación supletoria de la Ley de Enjuiciamiento Civil en materia de recusaciones y abstenciones por el reenvío del artículo 80 de la LOTC, en su redacción de 1979, lleva a aplicar unas reglas pensadas en un contexto bien distinto, la jurisdicción ordinaria donde los Magistrados pueden perfectamente ser sustituidos, al recurso directo en control normativo abstracto donde no existe contraposición de intereses públicos y privados. Ésta extravagante supletoriedad del sistema de recusación civil permite unos abusos que deberían ser corregidos mediante una regulación directa del asunto en la ley orgánica con modernos criterios de Derecho Procesal Constitucional, de manera análoga a la que v.gr. sigue la ley del Tribunal Constitucional federal en Alemania. Tanto la prórroga como la supletoriedad de la LEC en materia de recusaciones, a la vista de la experiencia, deberían ser derogadas de la LOTC, hay de sobras ejemplos de Derecho Comparado de países de nuestro entorno donde tales disposiciones no existen. Los poderes públicos se han habituado a un vicio, manipular la composición del tribunal, que debería ser erradicado desde la raíz en aras a la voluntad de de vivir en Constitución y de la imparcialidad del juzgador.

En definitiva, se ha generado una muy mala imagen de la institución, corolario del exagerado y conflictivo entorno que hemos respirado desde el principio del proceso de reforma del Estatut. Los partidos políticos han trasladado mecánicamente al debate jurisdiccional un enconado conflicto político, que debieron resolver previamente, generando compromisos en ambas sedes parlamentarias, y esto ha dañando seriamente -ojalá no sea de forma irreparable - la apariencia de imparcialidad del Tribunal. La situación desde luego no ha reforzado la autoridad del Tribunal, especialmente, en Cataluña.

En esta atmosfera enrarecida puede hacerse difícil de creer que en sala de enjuiciamiento — como ha sostenido Zagrebelsky — los tribunales constitucionales construyen y aplican principios jurídicos y no emiten votos en grupos ${ }^{3}$. La realidad puede ser a veces distinta, pero no cabe otra justificación de una verdadera jurisdicción constitucional que no puede ser un parlamento. Ciertamente, ningún tribunal — recuerdo haberlo leído en Volpe- puede abstraerse totalmente y actuar con la independencia del sabio Salomón en una sociedad convulsionada como la de Weimar ${ }^{4}$. Pero el intenso conflicto del Estatuto ha tenido unos muy elevados costes; uno de ellos es el daño al prestigio de la jurisdicción constitucional que costará reparar y sólo podría arreglarse, promoviendo excelencia y rigor en la selección de los Magistrados constitucionales, que son la sal de la tierra, su cualidad de juristas de reconocido prestigio es la misma condición de existencia de la juris-

3 G. Zagrebelsky: Principios y votos: el Tribunal Constitucional y la política, Trotta, Madrid, 2008.

4 G. Volpe: L'ingiustizia delle leggi. Studi sui modelli di giustizia costituzionale, (Cap. IV Salomone a Weimar), Giufré, Milán, 1977, pp. 65-247. 
dicción. Pero, por ahora, volvemos a no ir por buen camino, en diciembre de 2010, el nombramiento de los Magistrados, pese a estar ya elegidos por el Senado no fue publicado en el BOE hasta después de un largo lapso de treinta días, como medida de presión para alcanzar un acuerdo sobre los que a su vez debía nombrar el Congreso (que baraja una propuesta de candidato inaceptable para el resto) al mismo tiempo, incumpliendo el mandato de renovación escalonada. Mientras no sean erradicados estos hábitos, me temo no pueda sobrevivir mucho tiempo una jurisdicción constitucional de primer nivel. Y esa merma afectará antes o después a la eficacia en la solución pacífica de los conflictos constitucionales, y a la intensidad de la vinculación a la doctrina constitucional por parte de sus destinatarios.

Efectivamente, ha habido varios recursos frente al Estatuto de Cataluña, pero el principal fue el interpuesto por el Grupo Parlamentario Popular y resuelto por la larga STC 31/2010, de 28 de junio. Los demás recursos promovidos por varias Comunidades Autónomas han dado lugar a sentencias complementarias que sustancialmente se remiten a la primera. Las SSTC 46 y 47/2010, de 8 de septiembre, que enjuician los recursos presentados respectivamente por Aragón y las Islas Baleares frente a la Disposición Adicional Decimotercera, relativa al archivo de la corona de Aragón; y las SSTC 48/2010, de 9 de septiembre, y 49/2010, de 29 de septiembre, que resuelven impugnaciones de Murcia y la Comunidad Valenciana sobre cuencas hidrográficas. Asimismo, las más recientes STC de 16 de diciembre de 2010, derivada del amplio recurso promovido por el Defensor del Pueblo, y la sentencia de la misma fecha en el no menos amplio recurso del Gobierno de la Rioja, ambas declaran la pérdida sobrevenida de parte del objeto respecto de todas las impugnaciones resueltas por la STC 31/2010. Pero no me parece relevante detenerme en estos pronunciamientos sobre cuestiones más de detalle.

Más me preocupa que el control de constitucionalidad de los Estatutos se haya producido sobre leyes refrendadas algo que había sido desaconsejado doctrinalmente al discutirse en abstracto sobre el objeto del control de constitucionalidad de las leyes, pues la justicia constitucional fue diseñada para revisar leyes del Parlamento en un juicio de control normativo, y no decisiones del cuerpo electoral en referendum. No obstante, por supuesto, que cabe entre nosotros un control de constitucionalidad de los Estatutos refrendados en la medida en que están sometidos a la supremacía de la Constitución y que la ley orgánica dispone un procedimiento. No creo sean de recibo las tesis coyunturales que estos últimos tiempos han negado esta posibilidad. Pero es verdad que dista de ser el mejor de los procedimientos y nos evitaríamos problemas — de legitimidad de la decisión y de cumplimiento de las sentencias que en su caso demandasen modificaciones estatutarias - efectuando el control con anterioridad; recordaré que sobre esta cuestión ya debatimos en el Congreso de la ACE sobre la reforma del Tribunal Constitucional.

Por consiguiente, sí creo necesario recuperar en una reforma de la LOTC (estuvo en el derogado artículo 79.1) el recurso previo frente al texto definitivo del proyecto o proposición de Estatuto de Autonomía que haya de ser sometido a referendum. Un precepto que — como es sabido- desapareció de la ley al hilo de la lógica supresión del recurso previo frente a leyes orgánicas cuyo reiterado uso había dado lugar a prácticas de obstruccionismo parlamentario. Pero una cosa no debió llevar a la otra. No es procesalmente óptimo, impugnar leyes refrendadas, pues provoca dificultades tanto jurídicas como políticas. Sería más razonable recurrir la propuesta de Estatuto tras su aprobación por las 
Cortes Generales y antes de someterlo al referendo del cuerpo electoral de la Comunidad Autónoma afectada.

\section{Luciano Parejo Alonso}

En mi opinión, abundar en las circunstancias que han rodeado la sustanciación y resolución del recurso de inconstitucionalidad y, en tal contexto, la posición en la que se ha encontrado el Tribunal Constitucional tiene mas utilidad en otros órdenes que en el estrictamente jurídico-constitucional positivo, en el que no promete frutos sustanciales. Una vez sometida la reforma-revisión del Estatuto de Autonomía al escrutinio del Tribunal Constitucional, el desenlace responde, en lo sustancial, a lo que podía esperarse, teniendo en cuenta el planteamiento — desde la Generalitat y el Gobierno central y también las fuerzas políticas- de la iniciativa, las coordenadas del llamado «proceso autonómico» y la doctrina al respecto del propio Tribunal Constitucional (que, en este caso, ha sido rehén de si mismo, sobre todo en materia competencial). Con independencia del juicio que pueda merecer desde otras perspectivas, que sin duda obligan a tener en cuenta la enorme dificultad de la situación en que todos habíamos contribuido a colocar el Tribunal Constitucional, las líneas que siguen se sitúan estrictamente en el expresado terreno jurídico-constitucional positivo para analizar la articulación técnica de su Sentencia; tarea que, en todo caso, me parece inexcusable.

Lo único que en este último orden de cosas creo relevante es que el verdadero perdedor es aquí la Constitución misma: tras algo más de treinta años de vigencia, el núcleo de la decisión constituyente, es decir, la organización del Estado, sigue sin presentar al día de hoy los perfiles aceptablemente claros que su naturaleza demanda, de modo que —en lo que hace a su dimensión territorial — los planos del llamado Estado autonómico continúan estancados en un limbo que hace posible que la «construcción» se desarrolle —al parecer indefinidamente o sin horizonte final previsible - en clave de obra provisional capaz, falta de elementos estructurales fijos (paredes maestras portantes establecidas), de abocar a resultados edificatorios de tipología diversa, reputados, según quien, igualmente válidos.

La interesada ${ }^{5}$, ausencia de interrogación a fondo sobre esta aparente paradoja constitucional —constitución del Estado (autonómico) sin constitución siquiera principial o básica de toda su dimensión territorial — trae causa de la aceptación — como supuesta condición de su viabilidad — de una «apertura» y «flexibilidad» tales del supuesto «modelo territorial» constitucional que equivalen a su desdibujamiento vía afirmación de su pretendida desconstitucionalización ${ }^{6}$. En estas condiciones la normatividad de la Constitución no puede sino padecer, expuesta — como queda— a la presión política de proyección en

5 La asunción de la supuesta no resolución, en el momento constituyente y siquiera sea en sus líneas esenciales, de la articulación territorial y de su entrega, por tanto, al ulterior proceso político sin otros condicionantes que los cauces al efecto establecidos, implica soslayar la tarea de deducción del marco organizativo establecido sin duda por la Constitución para dejar expedito espacio suficiente a aquel proceso.

6 La afirmación por la doctrina del Tribunal Constitucional de la existencia en la Constitución de un modelo territorial aboca paradójicamente, así y en la práctica, a un resultado equivalente a su negación. 
ella de proyectos diseñados desde si mismos, al poder darse por supuesto su acomodación al orden constitucional. Porque implican el desplazamiento indebido al terreno jurídicopositivo constitucional de un problema de índole política, en cuyo ámbito propio es indudable la legitimidad de la formulación sin límites concretos de tales proyectos, incluso los desbordantes del actual orden constituido, con la sola condición de admitir la necesidad, en este último caso, de la reforma o revisión constitucionales. Resulta, en efecto, difícilmente comprensible para el ciudadano -sujeto, en los términos en que lo está, a las decisiones emanadas de los poderes constituidos por la Constitución- que estos poderes, responsables del proceso de «reflexión del Estado sobre si mismo» en que consiste el proceso autonómico, no estén sujetos, a tal efecto, a la Ley suprema no ya en parecidos términos ${ }^{7}$, sino ni siquiera en los de vinculación por un marco capaz de orientar y acotar las opciones posibles precisamente para «determinarse» en cuanto tales poderes públicos constituidos, de modo que se sientan en condiciones de proceder según diversas y sucesivas interpretaciones al respecto. Interpretaciones que, una vez aceptadas por el Tribunal Constitucional, hacen de la organización y el funcionamiento del Estado autonómico cada vez más complejo e inextricable, colocándolo, a la postre, en riesgo de caer en un galimatías.

Por más que el traje institucional territorial diseñado por la Constitución sea amplio, ni carece de forma y, por tanto, límites, ni, por tanto, posee una capacidad indefinida de asunción de soluciones organizativas. Ya en el estado que lo coloca la Sentencia, justamente por exceso en el recurso a la técnica de la «interpretación conforme», es duro de aceptar que el sentido y alcance del bloque de la constitucionalidad determinante de la disposición y el funcionamiento correctos de los poderes públicos en él implicados y, por tanto, de la integración del ordenamiento jurídico en el territorio de Cataluña sólo resulten, en muy buena medida, del manejo de las normas constitucional y estatutaria a la vista no ya del fallo, sino también y necesariamente de las consideraciones desarrolladas en los fundamentos jurídicos de la Sentencia. Lo que incrementa, en grado nada desdeñable, la inseguridad del resultado de la operación de aplicación del bloque de la constitucionalidad (contagiando aquélla al resto del ordenamiento, en el que forzosamente se multiplica), al punto de inducir la tentación de trasladar al Tribunal Constitucional el mismo reproche que éste hizo en su momento (1990) al Parlamento de Canarias.

La Sentencia está condicionada, a mi juicio, por la apuntada dilución parcial de la organización constitucional (que no es de ahora, ni exclusivamente debida al Tribunal Constitucional). De ésta deriva, en efecto, la clave (a mi juicio equivocada) de dicho pronunciamiento: la amorfa determinación que hace de la norma estatutaria para dotar a su contenido de potencia expansiva. Pues tal determinación condiciona todo el control de constitucionalidad aquí llevado a cabo, siendo así que -dada la organización territorial del Estado- el Estatuto de Autonomía es, sin duda, una norma de perfil preciso: el que le otorga su carácter organizativo o de establecimiento ${ }^{8}$ constituyente de un poder-ordenamiento constituido (la correspondiente Comunidad Autónoma) ${ }^{9}$. Y una norma orga-

7 Dado que la organización es, en cuanto corazón mismo del acto constituyente (la constitución de España en un determinado Estado, como reza el artículo 1.1 de la norma fundamental), materia de orden público y, por ello, ius cogens.

8 En el sentido que a «estatuto» otorga ya, en el lenguaje general, la primera acepción del diccionario de la Real Academia de la Lengua Española ( $22^{\mathrm{a}}$ ed.): establecimiento, regla que tiene fuerza de ley para el gobierno de un cuerpo. 
nizativa de decisiva importancia por su objeto: la ultimación, en su dimensión territorial, de la arquitectura del Estado como un todo. En tanto que la norma fundamental constituye éste como un todo (art. 1.1 CE) y las Comunidades Autónomas son parte de él, no otra función constitucional puede tener, en efecto, el Estatuto de Autonomía. Así lo dicen claramente los artículos 137 y 143.1 CE: si, a tenor del primero, el Estado se organiza territorialmente en Municipios, en Provincias y en las Comunidades Autónomas que se constituyan, conforme al segundo el acceso al autogobierno, en ejercicio del derecho a la autonomía, tiene lugar mediante el acto de las correspondientes colectividades territoriales consistente en «constituirse en Comunidades Autónomas con arreglo a lo previsto en este Título —el VII-y en los respectivos Estatutos». Y el artículo 152.1 CE (definitorio del modelo que han acabado siguiendo todas las Comunidades Autónomas, pero aplicable en todo caso a Cataluña) despeja ya cualquier duda, al determinar los elementos en que debe basarse necesariamente «la organización institucional autonómica» establecida por los Estatutos de Autonomía.

La condición organizativa del Estatuto de Autonomía se expresa en su precisa calificación (art. 147.1 CE) como norma institucional básica de la correspondiente Comunidad Autónoma. Pues con ella se alude a su función y efecto de institucionalizar ${ }^{10}$ la correspondiente colectividad territorial. Priva, pues, de cobertura constitucional suficiente a la argumentación de la que el Tribunal Constitucional pretende «deducir» un contenido variable (y, por tanto, también dispositiv ${ }^{11}$ ) de ésta, suma de un supuesto contenido necesario u obligatorio (el del art. 147.2 CE) y otro adicional meramente posible, desagregado, a su vez, en uno explícito ${ }^{12}$ y otro implícito ${ }^{13}$. En efecto:

9 Por lo mismo que la decisión constituyente del artículo 1.1 CE es, a la vez, del Estado como poder y como ordenamiento.

10 Ya en su sentido general, institucionalizar significa, según el Diccionario de la Real Academia de la Lengua Española (22a ed.), convertir algo en institucional, conferir el carácter de institución, e institución significa: en la primera acepción, establecimiento o fundación de algo; en la segunda, cosa establecida o fundada; en la tercera, organismo que desempeña una función de interés público; y en la cuarta, cada una de las organizaciones fundamentales de un Estado, nación o sociedad.

11 Lo que remite al verdadero y omnipresente trasfondo del razonamiento: la desconstitucionalización y el consecuente principio dispositivo del régimen de la pieza autonómica de la organización del Estado.

12 El derivado, en lo esencial, de preceptos constitucionales contentivos de mandatos constitucionales concretos y expresos (arts. 3.2; 4.2 y $69.5 \mathrm{CE}$ ). En realidad, no se está ante contenido adicional alguno, sino más bien — dada la unidad de la Constitución y la lógica precisamente de la organización territorial del Estadoante disposiciones constitucionales (ellas mismas organizativas) que, justamente por razón de su objeto (reconducible a lo institucional: la cooficialidad de la lengua hablada; banderas y enseñas propias; participación orgánica en la Cámara territorial de la instancia general o central), remiten a la norma institucional básica de la correspondiente Comunidad Autónoma y a su contenido constitucional propio.

13 El que, sin otra apoyatura que la «diversidad del ordenamiento» que la norma fundamental permite, se hace derivar de la función y cualidad de la norma estatutaria y que habilita a los Estatutos para integrar previsiones y disciplinas muy dispares, sin otras restricciones que las reservas constitucionales de Leyes específicas (en particular, orgánicas) y unos vagos y más bien teoréticos límites cuantitativos y cualitativos. Se trata de un contenido que carece de base en el texto constitucional, cuya afirmación incurre en círculo vicioso: la habilitación estatutaria para disciplinar las más variadas materias se hace derivar de la función y cualidad de dicha norma de cuya determinación (no efectuada) depende, a su vez, la validez de la afirmación de aquella habilitación. 
a) La doble prescripción (en un mismo precepto: art. 147 CE) de la caracterización del Estatuto de Autonomía como norma institucional básica y la imposición al mismo de un cierto contenido impide la afirmación sin más de la no determinación constitucional expresa de tal contenido. Pues la objeción a ella que representa no se salva con la mera calificación como mínimo del establecido por la norma (para permitir la existencia, injustificada, de uno meramente «posible»). De un lado, el artículo 147 CE no solo no da pie a tal calificación, sino que su redacción imperativa y el carácter taxativo o cerrado y no ejemplificativo o abierto de la enumeración de extremos que han de ser objeto de regulación más bien la excluyen. Exclusión que la conceptuación como norma institucional refuerza $^{14}$. Pues no parece que, según la instancia de cuya institucionalización se trate, la norma que la lleve a cabo pueda tener un alcance preciso (acotador de su función constitucional y, por tanto, de su contenido) y otro laxo y abierto (capaz de ampliar aquella función desde el derecho mismo al autogobierno cuyo espacio propio se trata justamente de acotar). Tanto más cuanto se trata de la articulación de la organización territorial del Estado y en modo alguno de la definición del orden político y social. Conforme al propio Tribunal Constitucional, en efecto, la remisión a la legislación ordinaria —en el mismo título de la norma fundamental y a idénticos efectos- del estatuto institucional de la autonomía garantizada a los entes necesarios de la Administración local tiene por objeto precisa y únicamente su gobierno y administración; expresión que comprende -agotándose en ellos, por institucionales - los aspectos organizativos y funcionales y, por tanto, los competenciales. La invocación tópica del superior contenido político de la autonomía de las Comunidades Autónomas y, por tanto, la admisión constitucional de la diversidad ordinamental, es ineficaz para justificar la diferenciación, tanto más cuanto que justamente lo que se trata de demostrar es que tal incuestionable diversidad ordinamental pueda - más allá de lo institucional u organizativo, es decir, en lo sustantivo o perteneciente al orden social - producirse precisamente en sede del Estatuto de Autonomía en tanto que norma meramente institucional y constitucionalmente no deba, por ello, tener lugar solo como consecuencia del ejercicio por los poderes estatuidos en tal norma institucional.

b) Abunda en lo dicho la inconsecuencia entre la expresada amplia concepción de la función y, por tanto, el contenido de la norma estatutaria (frustrante de toda clara acotación de la una y del otro, como resulta de la propia Sentencia ${ }^{15}$ ) con la caracterización

14 Tanto más si se tiene en cuenta la denominación constitucional de Estatuto de Autonomía, es decir, establecimiento de la autonomía o autogobierno (lo que conecta con el contenido constitucionalmente previsto para dicho Estatuto).

15 La afirmación por el Tribunal Constitucional de que la naturaleza y la función constitucionales de los Estatutos de Autonomía determinan su posible contenido no es, dado el contexto del razonamiento en que se realiza, sino pura retórica (en la primera acepción que da a este término el Diccionario de la Real Academia de la Lengua Española en su $22^{a}$ edición). Y el ensayo que realiza de identificación — que no concreción— de los límites constitucionales del contenido «posible» demuestra la inanidad de éstos: aparte las reservas constitucionales a favor de Leyes específicas o reservadas a Leyes orgánicas no estatutarias, que no son tanto limites específicos de la norma estatutaria, cuanto los exteriores o extremos de cualquier norma legal cuya relación con las demás se rija primariamente por el principio de competencia (en tanto que previsiones de reserva de decisión, en su caso a favor del Estado central), los llamados límites cuantitativos se diluyen en vagas referencias a la inadecuación de la norma estatutaria, por su rigidez y posición, como sede de decisiones normativas con significativo grado de detalle o en las que, por su objeto, sea conveniente una mayor participación política; y los 
previa de aquélla como especie de la categoría Ley orgánica a la que se reservan determinadas materias (¿cuáles?) y se relaciona con las demás Leyes con arreglo, en lo sustancial, al principio de competencia.

La prueba del completo desdibujamiento de la supuestamente precisa y especifica figura del Estatuto de Autonomía está en su posterior ${ }^{16}$ conceptuación, en tanto que norma precisamente institucional, como «norma primera de un sistema normativo autónomo» y «norma de cabecera del ordenamiento autonómico», lo cual es sustancialmente distinto que norma institucional que, en cuanto tal, articula y, por tanto, preside un sistema normativo autónomo. Lo es, en efecto, según el propio Tribunal Constitucional, cuando, a propósito de la impugnación de preceptos del título III relativo al poder judicial en Cataluña, señala textualmente que:

«En el Estado autonómico, en efecto, la diversificación del ordenamiento en una pluralidad de sistemas normativos autónomos no se verifica ya en el nivel de la constitucionalidad con la existencia de una pluralidad de Constituciones (federal y federadas), sino que, a partir de una única Constitución nacional, sólo comienza en el nivel de la legalidad. Los sistemas normativos que en ese punto se configuran producen normas propias, a partir del ejercicio de unas potestades legislativa y ejecutiva también propias» (la cursiva es del autor).

Pues, ultimando los Estatutos de Autonomía el proceso de «constitución» —en su dimensión territorial - del Estado y formando parte, por ello, del llamado «bloque de la constitucionalidad», parece que —a los expresados efectos- deben ubicarse, tras la Constitución misma, en un punto aún anterior al de diversificación del ordenamiento en los términos tan bien expresados. Y por ello mismo la acuñación constitucional de los Estatutos como normas institucionales, es decir, acantonadas en lo organizativo para dejar expedita la aludida diversificación según el modelo específico constitucional.

La cuestión del punto en que comienza la diversificación ordinamental es literalmente esencial, pues de ella depende la efectividad de la unidad constitucional, que reside también y principalmente en la del orden político y social (definido en el título I de la norma fundamental) más que sólo en la abstracta y enfática proclamación de la de la nación en cuanto sede de la soberanía de la que luego — como más tarde se verá- no se derivan consecuencias concretas tangibles algunas. Pues la unidad de la nación soberana lo es por, para y en el proyecto común de un preciso orden político y socia $1{ }^{17}$ y en ello radica justamente la peculiaridad del modelo sentado por la Constitución, como, por demás, el propio Tribunal Constitucional no deja de reconocer.

Sin mayor fundamento constitucional se pasa aquí, por tanto, de lo institucional a la ordenación político-social (en el ámbito competencial correspondiente). Y una ordenación - como objeto posible de la norma estatutaria - cuyos límites son, como ya se vio y ahora se confirma plenamente, más que difíciles de establecer:

límites cualitativos se reconducen al genérico — que vale para todos los poderes públicos constituidos y no es específico de a la autonomía territorial— de imposibilidad a asunción de la posición del poder constituyente (la adopción de decisiones soberanas).

16 A propósito del examen del título I, relativo a los derechos, deberes y principios rectores, primero, y de la financiación autonómica y, más concretamente, la regulación de la Agencia Tributaria de Cataluña, luego.

17 A este propósito, con mayor detalle, L. PAREJo AlFonso, «España, estado español y Constitución», en A. Rodríguez de Las Heras, V. Baez y P. Amador (Eds) Sobre la realidad de España, UC3M/BOE, Madrid, 1994 , pp. 159 a 186. 
- El despacho de la cuestión que plantean los preceptos estatutarios de ordenación social que reconocen o prefiguran derechos o establecen principios directivos con el simple expediente de afirmar, por un lado, que los derechos, debiendo ser cosa distinta a los constitucionales que vinculan con carácter general a todos los poderes públicos, lo son por el mero hecho de vincular solo a los poderes públicos de Cataluña y acotarse por relación al ámbito material de las competencias de ésta, y, por otro lado, los principios prescriben fines y legitiman la ordenación de los medios públicos al servicio de éstos, apelando al legislador materialmente competente, simplemente soslaya el problema fundamental de la idoneidad de la norma estatutaria para incluir tal tipo de normas y confirma, a pesar de ello, que los Estatutos de Autonomía son normas cuyo objeto y contenido no se circunscribe a lo institucional.

- La supuesta restricción que, ante la amplitud de la consecuencia que deriva de la anterior confirmación, se busca en la apelación a la distribución competencial genérica entre las Leyes orgánicas revela la ya comentada impracticabilidad de la fijación de límites precisos al contenido de la norma estatutaria resultante de la concepción asumida. Tal apelación, en efecto:

i) Incurre, por de pronto, en argumentación circular, al tener que recurrir - para excluir el desarrollo de los derechos fundamentales de la función estatutaria- justamente a la condición de norma institucional, aparte de su vigencia territorial limitada.

ii) Tropieza en la ya comentada dificultad de precisión de cualesquiera límites sustantivos verdaderamente operativos, desembocando, a partir de la invocación de la condición institucional, en una identificación teorética e imprecisa de los límites funcionales (los propios del ámbito de la generalidad, abstracción y los principios por contraste con el ámbito del desarrollo) que no hace otra cosa, además, que corroborar el reconocimiento del carácter de norma idónea para la ordenación social.

iii) Lleva, por razón de la traída a colación de la vigencia territorial limitada, a una afirmación — la afectación del principio de igualdad de los españoles por razón de la eventual pluralidad de regulaciones estatutarias en materia de derechos fundamentalesque, para ser convincente, habría precisado de un mayor desarrollo en atención a la doctrina del propio Tribunal de que la igualdad no implica uniformidad. Por lo que se entiende, o no, según se considere, su formulación escueta.

iv) Aboca a un argumento que pone en cuestión la tesis a la que sirve, cuando, como a modo de complemento del antes comentado relativo a la distribución competencial entre las Leyes orgánicas, alude a la divisoria constitucional entre éstas y las ordinarias en la misma materia de derechos fundamentales para negar al legislador estatutario, en tanto que orgánico, cualquier disposición sobre los derechos fundamentales, por ser aquélla propia - conforme al reparto territorial de competencias- del legislador ordinario autonómico. Pues la pertenencia natural, por razón del orden constitucional, de aquella disposición a este legislador es el principal de los argumentos esgrimibles contra la dilución de la decisión constitucional directa y clara de otorgamiento a los Estatutos de Autonomía de carácter y función estrictamente institucionales.

Cuestión distinta a la hasta aquí analizada es la de si sería conveniente la reintroducción del recurso previo de inconstitucionalidad. Mi respuesta a ella, consecuente con el carácter singular y la función y posición constitucionales específicas de la norma estatutaria que acaban de afirmarse, es positiva, pero solo en términos de procedencia de al- 
gún pronunciamiento del Tribunal Constitucional en momento procedimental oportuno. Pues más que el recurso previo de inconstitucionalidad, la pertinencia de cuya reintroducción a este propósito es más bien discutible, procedería a mi juicio — por ajustarse bien al carácter, función y posición de las normas estatutarias - una solución análoga, si no idéntica, a la derivada de la prohibición constitucional de celebración de tratados contrarios a la Constitución (art. 95 CE): la declaración por el Tribunal Constitucional, con carácter previo a su tramitación parlamentaria y a requerimiento del Gobierno o de cualquiera de las Cámaras, de la existencia o no de contradicción con la norma fundamental del correspondiente proyecto de reforma o revisión de un Estatuto de Autonomía. No creo que la directa previsión del objeto del recurso de inconstitucionalidad por el artículo 161.1, a) CE sea un obstáculo insalvable a tal efecto.

2. ¿Qué nos desea decir sobre el valor que la Sentencia a que nos referimos otorga al preámbulo del Estatuto, a la mención del mismo a que se había concebido a Cataluña por el Parlament como «Nación» y sobre otros puntos conexos?

\section{ROBERTO BLANCO VALDÉS}

Creo que lo más relevante de esta parte del la Sentencia — aunque no de la Sentencia en su conjunto, ni del pleito que esta resuelve- es lo relativo a la cuestión de los derechos históricos y a la mención de Cataluña como nación. Considero que en ambos casos el TC sienta principios de partida inimpugnables, aunque en los dos el propio Tribunal acaba siendo sorprendentemente incoherente con ellos, al no anular preceptos que según tales principios deberían haber sido declarados inconstitucionales. En el supuesto de los derechos históricos el aludido principio de partida es el de que el precepto estatutario que se refiere a ellos $\left(\right.$ art. $5^{\circ}$ ) «sería manifiestamente inconstitucional si pretendiera para el Estatuto de Autonomía, un fundamento ajeno a la Constitución, aún cuando fuera añadido al que ésta le dispensa». La simple lectura del artículo, en el que, entre otras cosas, se establece que «el autogobierno de Cataluña se fundamenta también en los derechos históricos del pueblo catalán» deja bien claro que su objeto (fundamentar el autogobierno de Cataluña también en los derechos históricos del pueblo catalán, es decir, en tales derechos, además de en la Constitución, de acuerdo con la cual Cataluña ejerce su autogobierno) es precisamente el que el TC considera manifiestamente inconstitucional. Por si quedara duda alguna a ese respecto, el propio preámbulo del Estatuto, que, como todos los de su clase y según una ya asentada doctrina del Tribunal, tiene un valor jurídicamente cualificado como pauta de interpretación de las normas respectivas (STC 36/1981, doctrina refrendada por el TC en la propia sentencia 31/2010: «El valor jurídico de los preámbulos de las leyes se agota, por tanto, en su cualificada condición como criterio hermenéutico»), lo dispone con una meridiana claridad: «El autogobierno de Cataluña se fundamenta en la Constitución, así como en los derechos históricos del pueblo catalán [.... .». Pero el Tribunal salva la inconstitucionalidad del artículo $5^{\circ}$ por el simple expediente —que utilizará de forma recurrente en su Sentencia- de hacer decir a una disposición lo que manifiestamente no dice o de afirmar que no dispone lo que manifiestamente dispone: en esta caso se tratará 
de lo segundo, al sentenciar que la referencia a tales derechos históricos puede ser salvada porque aquella sólo se incluye en el texto estatutario con el objeto de sostener la posición singular de Cataluña en relación con determinadas materias, lo que supone a mi juicio desconocer la propia literalidad del precepto impugnado.

En cuanto a la cuestión del término nación, lo cierto es que la doctrina, que me parece discutible, aunque aceptable, sentada por el TC en relación con el valor jurídico del preámbulo (la de que ha de ser al hilo del enjuiciamiento de los preceptos impugnados a los que el preámbulo hace referencia cuando el Tribunal se pronuncie «también sobre la interpretación de los mismos que eventualmente cupiera deducir de los referidos párrafos del preámbulo y cuando, en consecuencia, de concluir que dicha interpretación es constitucionalmente inadmisible, se prive al preámbulo, en ese punto, del valor jurídico que le es característico, esto es, de su condición de interpretación cualificada») debería haber llevado al Tribunal a deducir que el preámbulo del Estatuto viene apoyar la idea de que la voluntad del legislador fue la de definir de un modo u otro a Cataluña como nación fijando coherentemente con ello sus símbolos nacionales. Muy lejos de tal forma de enjuiciar, el TC, partiendo de nuevo de un principio que creo evidente (el de que, en sentido jurídico-constitucional, «la Constitución no conoce otra nación que la española») decide, sin embargo, no sacar la consecuencia jurídica lógica de tal formulación, que no podía haber sido otra que la anular los preceptos que predican para Cataluña una naturaleza de la que jurídico-constitucionalmente carece porque en tal ámbito no puede poseerla. El Tribunal retuerce de nuevo las palabras, en mi opinión, para hacer compatible con la Constitución lo que de otro modo no lo sería. Sólo así cabe interpretar su tesis de que «con la calificación como nacionales de los símbolos de Cataluña se predica únicamente su condición de símbolos de una nacionalidad», afirmación que constituye una mera petición de principios al carecer de la más mínima base en que sustentarse, pues nacional (o su plural nacionales) es según el Diccionario «lo perteneciente o relativo a una nación».

Por si ello fuera poco, el TC resuelve uno de los asuntos más discutidos en su seno (el de la constitucionalidad o no de los términos «nación»y «realidad nacional» referidos a Cataluña, contenidos en el preámbulo de la norma) con la doctrina, que lleva al fallo, de que ambos términos carecen de eficacia jurídica interpretativa, lo que, según ya he sostenido en otro lugar ( «El Estatuto de Cataluña y la sentencia de nunca acabar», en Claves de Razón Práctica, nº 205, 2010), constituye, más allá de cualquier consideración jurídica, un brindis al sol por dos tipos de motivos diferentes: primero, porque en el plano del derecho interno resulta inimaginable cual podría ser la eficacia jurídica interpretativa de tales términos aunque el TC no la hubiera negado de forma taxativa; y, segundo, porque en el plano del derecho internacional —mucho más relevante sin duda para los impulsores del texto- es igualmente difícil de imaginar que el fallo del Tribunal pueda privar de potencialidad reivindicativa a una norma de derecho interno que dispone, sin que el TC lo haya anulado, que Cataluña es una nación y que tiene símbolos nacionales.

\section{RAÚl CANOSA UsERA}

El fallo de la STC 31/2010 priva a las referencias a «Cataluña como Nación» y a la «realidad nacional catalana», contenidas en el Preámbulo del Estatuto, de todo valor in- 
terpretativo y se da a los términos «nacional» o «nacionales», empleados en algunos de sus preceptos, una interpretación conforme al conectarlas con la expresión «nacionalidades» contenida en el artículo 2 CE. Para el TC la única Nación es la española, indisoluble según este precepto, e identificada con el pueblo español, al que se atribuye la soberanía nacional (art. 1.2 CE). Se desactivan así, por añadidura, posibles interpretaciones de otros términos estatutarios, tales como «ciudadanía catalana» o «pueblo de Cataluña» que podrían haberse entendido conectados con la nación catalana, alumbrando un sujeto político nuevo que aspirase a gozar de una soberanía, equiparable a la española o parangonable.

No parece caber ninguna duda, en mi opinión, acerca de la firmeza con la que la Constitución zanja el asunto de la titularidad de la soberanía y de la diferencia entre su manifestación pristina: el poder constituyente reservado a la Nación española, y la autonomía de nacionalidades y regiones expresada como poder estatuyente, además compartido con el Estado y limitado por el constituyente. Si el Estatuto, como se infiere de la STC 31/2010, desborda los límites de lo permitido al poder estatuyente, la alusión a la Nación catalana, que subsistió en el Preámbulo, luego de ser eliminada del articulado durante su tramitación en las Cortes Generales, parecía recalificar a Cataluña como Nación y, desde esta consideración, justificar, por un lado, las novedades estatutarias y, por otro, realzar simbólicamente la singularidad catalana. Una cosa y la otra han sido descartadas por el TC, tal vez con una rotundidad que han deplorado varias fuerzas políticas. ¿Podría haberse evitado este malestar con una argumentación más cuidadosa? No estoy seguro de que introducir en la sentencia la distinción entre nación política (la española) y naciones culturales (la catalana y eventualmente otras) no generase el mismo tipo de polémica que la resuelta en 1978 con la introducción del concepto de nacionalidad. La pretensión de crear una España plurinacional habrá de quedar para una reforma constitucional.

\section{Francesc de Carreras Serra}

Contrariamente a lo que se ha repetido hasta la saciedad en las declaraciones de políticos partidarios y contrarios al Estatuto, así como en muchos comentarios, de signo muy distinto, aparecidos en los medios de comunicación, en ningún momento el Estatuto establece, ni en el preámbulo ni en la parte dispositiva, que Cataluña sea una nación.

$\mathrm{El}$ art. 1 EAC dice claramente que Cataluña es una nacionalidad utilizando una formulación prácticamente igual al art. 1 del Estatuto de 1979. Así pues, no hay problemas de encaje entre este art. 1 EAC y el art. 2 CE: Cataluña es una nacionalidad con derecho a la autonomía. Ahora bien, en el preámbulo se alude a esta cuestión de forma algo ambigua — ambigüedad, por supuesto, calculada e intencionada — y con un contenido impropio de un preámbulo. En efecto, allí se cuenta el siguiente relato: «El Parlamento de Cataluña, recogiendo el sentimiento y la voluntad de la ciudadanía de Cataluña, ha definido de forma ampliamente mayoritaria a Cataluña como nación. La Constitución Española, en su artículo segundo, reconoce la realidad nacional de Cataluña como nacionalidad». Se trata de un texto descriptivo, que algún error contiene, y que puede dar lugar a confusiones interpretativas. 
Lo cierto es que, efectivamente, el Parlamento de Cataluña definió a Cataluña como nación en el proyecto de Estatuto aprobado el 30 de septiembre de 2005. El apartado 1 de su art. 1 únicamente decía: «Cataluña es una nación». Es cierto también que el Parlamento aprobó el proyecto de forma ampliamente mayoritaria. Ya es más dudoso, e imposible de probar, que esta definición recogiera «el sentimiento y la voluntad de la ciudadanía de Cataluña». En todo caso, Cataluña es plural y sobre este controvertido tema, según los sondeos, no existe el alto grado de coincidencia que parece expresar el preámbulo. Por último, no es cierto el inciso final: «la Constitución Española, en su artículo segundo, reconoce la realidad nacional de Cataluña como nacionalidad». Lo que reconoce el artículo $2 \mathrm{CE}$ es que España está integrada por nacionalidades y regiones con derecho a la autonomía, sin ninguna referencia expresa a Cataluña ni a cualquier otra nacionalidad o región.

Ahora bien, este texto, tanto por su inclusión en el preámbulo como por su lenguaje descriptivo y no prescriptivo, no tiene fuerza normativa aunque sí puede ser utilizado como elemento interpretativo del Estatuto. Ciertamente, el art. 1 EAC deja meridianamente claro que Cataluña es una nacionalidad (»Cataluña, como nacionalidad, ejerce su autogobierno constituida en Comunidad Autónoma de acuerdo con la Constitución y con el presente Estatuto, que es su norma institucional básica») y, por tanto, sólo tiene derecho a la autonomía. Ahora bien, la sentencia, en muchos de sus fundamentos, y aunque lo niegue, denota una gran desconfianza respecto al desarrollo del Estatuto que pueda llevar a cabo el legislador catalán. Es en ese sentido que la sentencia tiene un indudable carácter preventivo, es decir, examina a la luz de la Constitución la validez de los preceptos recurridos calculando las consecuencias constitucionales de su efectividad futura. ¿Es ello lícito? Permítanme que aproveche la ocasión para hacer unas consideraciones generales al respecto.

Ciertamente, el TC tiene vedado por su propia doctrina hacer juicios preventivos de las leyes y debe limitarse a juzgar los preceptos en sí mismos y no por sus virtuales consecuencias. Ahora bien, en el caso de un Estatuto, creo que está justificado el juicio preventivo si nos atenemos a su función. En efecto, se trata de una ley cuyos preceptos tienen más vocación de desarrollo legislativo que de aplicación directa. Si a ello añadimos el carácter ambiguo e indeterminado de muchos de sus preceptos, el escaso rigor técnico de los mismos que obviamente genera confusión y las frecuentes contradicciones de su texto, creo que entra dentro de las funciones del Tribunal, máximo defensor de la Constitución, advertir que determinados desarrollos legislativos pueden incurrir en vicio de inconstitucionalidad para que el Parlamento y el ejecutivo catalán lo tengan en cuenta al ejercer sus respectivas funciones legislativas.

El caso del citado párrafo del preámbulo es una aplicación, casi podría decirse que extrema, de este carácter preventivo de la sentencia. En efecto, en la declaración primera del fallo se estima que «carecen de eficacia jurídica interpretativa las referencias del Preámbulo del Estatuto de Cataluña a 'Cataluña como nación' y a la 'realidad nacional de Cataluña'.» Ciertamente, se trata de una novedad en la práctica del Tribunal, tanto por recoger en el fallo la adecuación o no de un preámbulo a la Constitución, como por declarar que dicho preámbulo, en alguna de sus partes, no tiene eficacia jurídica interpretativa. Algunos mantienen que se trata de una extralimitación del Tribunal, el cual sólo está facultado para declarar la nulidad de las normas de la parte dispositiva. Sin embar- 
go, dado que la función básica del Tribunal es garantizar la primacía de la Constitución sobre el resto del ordenamiento — asegurando así lo que disponen el art. 9.1 CE y 27.1 LOTC, entre otros - , negar eficacia jurídica interpretativa a determinadas expresiones del Preámbulo es la mejor manera de hacer efectiva esta labor de defensa del texto constitucional, amparando así dicho texto frente a posibles normas posteriores aprobadas por el legislador. Se trata, sin duda, de una innovación, pero no veo razones para considerarlo como algo anómalo dentro de las funciones del Tribunal.

Respecto al contenido de la sentencia sobre el término nación y a sus implicaciones, el Tribunal hace un razonamiento claro y obvio. Cataluña, tal como se deduce de su Estatuto en el marco de los arts. 1.2 y 2 CE, no es una nación en el sentido constitucional del término, es decir, no es una nación con un significado equivalente a «pueblo dotado de soberanía», como es el caso de España. Cataluña, desde un punto de vista constitucional, solo puede ser una nacionalidad, tal como lo proclama explícitamente el tan citado art. 1 EAC. Como tal nacionalidad, tiene derecho a la autonomía que, en la interpretación del Tribunal, equivale a autogobierno dentro del marco señalado por la Constitución. Así pues, el término "pueblo catalán» no es equiparable al término «pueblo español» del art. 1.2 CE, sujeto de la soberanía, sino que se refiere simplemente al «conjunto de ciudadanos españoles que han de ser destinatarios de las normas, disposiciones y actos» emanados de la Generalitat; ciudadanos que son, a su vez, los que participan en la formación de la voluntad de los poderes de dicha institución de autogobierno.

\section{MARC CARRILLO LÓPEZ}

Aunque la doctrina constitucional, por supuesto, no ha de ser inmutable, cabe señalar de entrada que en relación al valor que la sentencia atribuye al preámbulo del Estatuto, se aprecia una notoria incoherencia del Tribunal con la jurisprudencia anterior acerca de la justiciabilidad de los preámbulos ante la jurisdicción constitucional. Después de reiterar en el FJ 7 que el preámbulo no tiene valor normativo (STC 36/1981, FJ 2), siendo por ello innecesario, y hasta incorrecto, hacerlo objeto de una declaración de inconstitucionalidad expresa que se recogiera en la parte dispositiva (STC 116/1999, FJ 2), añade, de acuerdo con reiterada doctrina, que los preámbulos «no puede ser objeto directo de un recurso de inconstitucionalidad» (SSTC 36/1981, FJ 7; 150/1990, FJ 2; 212/1996, FJ 15 y 173/1998 FJ 4). Sin embargo, con motivo del recurso de inconstitucionalidad presentado contra el Estatuto el Tribunal modifica el criterio y, en este punto, lo admite a trámite. Cuando lo coherente con esta doctrina es que en este apartado referido al preámbulo, el recurso hubiese sido inadmitido.

Sin embargo, en este caso adopta otro criterio para establecer ahora que, «la carencia de valor normativo no equivale a carencia de valor jurídico, del mismo, del mismo modo que la imposibilidad de erigirse en objeto directo de un recurso de inconstitucionalidad no supone que los preámbulos sean inaccesibles a un pronunciamiento de nuestra jurisdicción en tanto que posible objeto accesorio de un proceso referido principalmente a una disposición normativa...». Y ello le lleva a entrar en el fondo de la cuestión y, además, incorporar en el apartado primero del fallo una singular decisión por la que establece que «carecen de eficacia jurídica interpretativa 
las referencias del preámbulo del Estatuto de Cataluña a "Cataluña como nación» y a «la realidad nacional de Cataluña». Singular, porque no es una declaración de inconstitucionalidad ni tampoco responde al carácter de una decisión interpretativa. Porque si se hubiese tratado de una decisión de esta naturaleza, el fallo debería haber precisado que la constitucionalidad del preámbulo en este punto era constitucionalidad si se interpretaba de una determinada forma o bien habría de haber formulado que sería inconstitucional si se interpretaba de manera distinta a la propugnada. El Tribunal ha adoptado un tertium genus, de ahí la singularidad a la que me refiero.

Sobre la cuestión principal que es objeto de enjuiciamiento por el Tribunal, esto es, la definición de Cataluña como nación por parte del Parlamento, por obvio que sea parece necesario recordar que el concepto de nación no es jurídico, sino político o sociológico que en sí mismo carece de valor normativo. Por esta razón, y sin ignorar la indudable trascendencia política que el concepto puede tener y sin duda tiene, como tal, carece de relevancia jurídica de la que se deriven derechos subjetivos para los ciudadanos. La idea de nación, en sí misma, no conduce a la determinación de un específico statuts jurídico para los ciudadanos del conjunto de un Estado ni, en su caso, para los ciudadanos de una comunidad singularizada políticamente a lo largo de su historia, e integrada jurídicamente en dicho Estado. La idea de nación, a diferencia del concepto de Estado, no está forzosamente vinculada a la de soberanía, salvo que erróneamente- - se identifique la nación con el Estado, como dos elementos de un binomio inescindible. Pero si se prescinde de dicha identificación, nada impide que en el seno del Estado jurídicamente soberano convivan naciones distintas. Sólo cuando aparece el concepto de soberanía vinculado al Estado-nación se derivan consecuencias jurídicas que se concretan, por ejemplo, en los requisitos para la adquisición y pérdida de la ciudadanía y de los que derivan derechos y deberes para sus nacionales (todos los ciudadanos españoles sin distinción), como prescriben los arts 17 a 28 del Código Civil. En ese caso es cuando la idea de nación, al vincularse a los ciudadanos como titulares en su conjunto de la soberanía (los ciudadanos españoles en su conjunto), adquiere efectos jurídicos. Y ello sólo es predicable del Estado-nación. Pero dentro del mismo, nada impide la existencia de comunidades políticas que puedan considerarse como naciones ni, por tanto, que el Estado pueda englobar, en sentido político, una pluralidad de naciones.

Éste era el sentido del barroco y no por ello menos importante y decisivo, en términos políticos, artículo 2 de la Constitución y que ningún precepto del Estatuto cuestionaba ${ }^{18}$ : «La Constitución se fundamenta en la indisoluble unidad de la Nación española, patria común e indivisible de todos los españoles, y garantiza el derecho a la autonomía de las nacionalidades y regiones que la integran...». Así era, en efecto, se refiere a nación y nacionalidades, sin que en ningún momento estableciese distinción alguna entre ambos conceptos, ni menos que de ellos se derivasen consecuencias jurídicas. De hecho, en los debates constituyentes fueron diversos los diputados que entendieron que el término nacionalidad era sinónimo de nación y algunos, como es sabido, plantearon la posibilidad

18 Buena prueba de ello es el contenido del artículo 1 del Estatuto: «Cataluña, como nacionalidad, ejerce su autogobierno constituída en comunidad autónoma de acuerdo con la Constitución y con este Estatuto, que es su norma institucional básica» 
de que España fuese entendida como una «nación de naciones», mientras que otros parlamentarios, juntamente para oponerse a que el término nacionalidades apareciese en el art. 2 sostuvieron que quería decir lo mismo que nación ${ }^{19}$. Fuera como fuese, y aún reconociendo el carácter limitado de la referencia a los antecedentes legislativos como criterio hermenéutico, lo que merece aquí ser subrayado es que todos estos conceptos no transcienden el ámbito de lo político y carecen de eficacia jurídica.

De acuerdo con estos presupuestos en el juicio de constitucionalidad que correspondía hacer al Tribunal Constitucional, a mi parecer, resultaba indiferente que la calificación de Cataluña como nación apareciese en el preámbulo del Estatuto como así fue finalmente, o que hubiese permanecido en el su parte dispositiva, es decir en el art. 1.1 que es lo que establecía la Propuesta de reforma del Estatuto aprobada por el Parlamento de Cataluña el 30 de septiembre de 2005, que establecía que: «Cataluña es una nación» Porque en ambos casos el precepto no era jurídico sino político. Como también lo es la parte del art. 2 de la Constitución, que concierne a los conceptos de nación, patria, nacionalidades, etc... En consecuencia, más allá de reconocer la carencia de eficacia jurídica del concepto de nación aplicado a cualquier comunidad política (España, Cataluña, etc.), el tema debería haber quedado agotado aquí. Y tampoco hubiese ido mal prescindir de reiterar las retóricas y nada jurídicas referencias del tenor de: «la Constitución misma, cuyo fundamento es la Nación española, indivisible y única» (FJ 8); «la Constitución no conoce otra que la Nación española...» (FJ 12); «... las normas del Ordenamiento no puede desconocer ni inducir al equívoco en punto a la «indisoluble unidad de la Nación española... ». De acuerdo con los argumentos expuestos, había buenas razones para haber prescindido en todo caso de la infortunada y preventiva incorporación del primer apartado del fallo que ha hecho la sentencia, acerca de la carencia de eficacia jurídica interpretativa contenidas en el Preámbulo del Estatuto a «Cataluña como nación» y a «la realidad nacional de Cataluña».

Lo esencial de estos argumentos ha de servir también para considerar que las referencias a símbolos nacionales debería haber tenido también un recorrido argumental mucho más breve y menos retórico. Además, hay que tener en cuenta que a lo largo de las tres décadas ya transcurridas de autonomía política en Cataluña, se han aprobado leyes en la que la expresión nacional forma parte de su denominación. Así, la Ley 1/1980, de 12 de junio, de la Diada nacional (fiesta nacional) o la Ley 1/1993, de 25 de febrero, del himno nacional. Ninguna de ellas fue impugnada ante el Tribunal Constitucional. Asimismo cabe constatar la proliferación, sobre todo, en el ámbito de las infraestructuras culturales del uso de adjetivo nacional para referirse, por ejemplo al Museo Nacional de Arte de Cataluña; la Orquesta Ciudad de Barcelona y Nacional de Cataluña; CataluñaRadio, la radio nacional de Cataluña, etc., sin que el apelativo derivado de nación tenga por sí mismo ninguna trascendencia jurídica, ni de ello se derive ningún tratamiento jurídico diferenciado para los usuarios.

Finalmente, la referencia a los derechos históricos del art. 5 EAC que la norma estatutaria incorpora y actualiza, tampoco habría de demandar el espacio que la sentencia

19 Vid. Dictamen del Consell Consultiu de la Generalitat de Catalunya, núm 269, de 1 de septiembre de 2005, FJ I (sobre la propuesta de Proposición de Ley orgánica, por la que se establece el Estatuto de autonomía de Cataluña). 
le dedica, puesto que es el propio Estatuto quien establece que la fuente primera en la que se fundamentan es la Constitución y no otra norma (de acuerdo con el art. 2, la Disp. Trans $2^{\mathrm{a}}$ y otros preceptos de la norma suprema que tengan relación con: el derecho civil, la lengua, la cultura, la educación y el sistema institucional). Era evidente que este precepto el Estatuto no se remitía a una doble legitimidad.

\section{Javier Corcuera Atienza}

Permítaseme, antes de entrar en este tema, hacer un comentario previo. Acabo de referirme a las dificultades políticas que dificultaron la aprobación de la sentencia y a la conveniencia de haber abordado de forma consensuada la reforma del modelo. Entre otros aspectos, ello hubiera obligado a atender al recurrente tema de la simetría o asimetría del sistema o, más explícitamente, al grado de singularidad que deberían tener Euskadi y Cataluña.

No oculto mi preferencia por un modelo inspirado en la lógica federal, en que la posición de todas las Comunidades sea básicamente igual, y en que las invocaciones a historia o carácter nacional, nacionalitario o regional carezcan de trascendencia jurídica. Pero es obvio que existen posturas favorables a la asimetría, y no sólo entre sectores más o menos nacionalistas. Precisamente por eso parece necesaria la reflexión sobre el conjunto del sistema.

Volviendo a Cataluña, no puede ignorarse el peso que han tenido en el proceso de elaboración y revisión del Estatut los elementos identitarios, ni la frustración colectiva que se ha manifestado en la última parte de aquel proceso. No solo han sido juristas catalanes quienes han defendido la intangibilidad de un Estatuto aprobado por mayoría absoluta de dos Parlamentos y por una mayoría del electorado catalán. Tal tipo de argumentos, al margen de su (in)consistencia, tienen el riesgo de justificar actitudes de deslegitimación del sistema constitucional que ningún favor hacen a la consolidación del sistema democrático.

Ello supuesto, y habida cuenta del amplísimo número de los artículos tachados de inconstitucionalidad por los diversos recurrentes, el Tribunal Constitucional debía conjugar la necesaria definición de lo inconstitucional con la prudencia de limitar el alcance de su sentencia sobre el texto del Estatuto. Este es el significado de una actitud que ha buscado, quizá con exceso, salvar la redacción estatutaria distinguiendo entre interpretaciones conformes y contrarias a la Constitución. Cierto es que la técnica tiene riesgos, y cierto que no han faltado ocasiones en que el intérprete constitucional ha llegado a hacer decir al legislador cosas que aparentemente no decía. A pesar de todo, me parece una actitud prudente y que ha permitido dejar claro qué es lo inconstitucional.

Vayamos ahora al preámbulo del Estatuto y, en particular, a la mención a la «Nación» catalana. Ha considerado el Tribunal, reiterando doctrina anterior, que un preámbulo no tiene valor normativo, por lo que no es susceptible de ser objeto directo de un recurso de inconstitucionalidad. Pero «la carencia de valor normativo no equivale a carencia de valor jurídico»: «los preámbulos y exposiciones de las leyes (...), sin prescribir efectos jurídicamente obligados y carecer, por ello, del valor preceptivo propio de las normas de Derecho, tienen un valor jurídicamente cualificado como pauta de inter- 
pretación de tales normas. Su destinatario es, pues, el intérprete del Derecho antes que el obligado a una conducta que, por definición, el preámbulo no puede imponer».

¿Qué puede deducir el intérprete del Estatuto de un preámbulo que habla de «realidad nacional de Cataluña», y afirma que «el Parlamento de Cataluña, recogiendo el sentimiento y la voluntad de la ciudadanía de Cataluña, ha definido de forma ampliamente mayoritaria a Cataluña como nación»? El texto constitucional plantea en su artículo segundo una distinción entre «nacionalidades»y «regiones» cuyo alcance jurídico se dejó en manos del legislador estatutario. La generalización del término llevó a que las inicialmente consideradas «nacionalidades», País Vasco, Cataluña y Galicia, invocaran su carácter nacional para reclamar una singularidad autonómica. Ciertamente, se trataba de un argumento primordialmente político, aunque la incorporación del término al Estatuto (explícitamente en la propuesta de «Estatuto Político de la Comunidad de Euskadi» y de modo más elíptico en el catalán) intentaba reforzar su significado jurídico.

La sentencia del Tribunal Constitucional, al negar alcance jurídico al preámbulo, deja las cosas como estaban, también en lo que toca al impreciso uso del término «nación». En el sentido jurídico-constitucional, que es el que le importa, la Constitución no conoce más nación que la Nación española: «las normas del Ordenamiento no pueden desconocer ni inducir al equívoco en punto a la «indisoluble unidad de la Nación española» proclamada en el art. $2 \mathrm{CE}$, pues en ningún caso pueden reclamar para sí otra legitimidad que la que resulta de la Constitución proclamada por la voluntad de esa $\mathrm{Na}$ ción, ni pueden tampoco, al amparo de una polisemia por completo irrelevante en el contexto jurídico-constitucional que para este Tribunal es el único que debe atender, referir el término «nación» a otro sujeto que no sea el pueblo titular de la soberanía.»

La polisemia se reconoce y se utiliza. Pese a lo que acaba de señalarse, entiende el Tribunal que es posible una interpretación conforme con la Constitución de la mención estatutaria a la existencia de símbolos nacionales de Cataluña, calificación que «se predica únicamente su condición de símbolos de una nacionalidad constituida como Comunidad Autónoma en ejercicio del derecho que reconoce y garantiza el art. 2 CE». No parece importar que, para la Real Academia Española, el término se vincule siempre con «nación»: para el Tribunal, nada obsta a que «en cualquier contexto que no sea el jurídico-constitucional la autorepresentación de una colectividad como una realidad nacional en sentido ideológico, histórico o cultural tenga plena cabida en el Ordenamiento democrático como expresión de una idea perfectamente legítima». El problema está en que el significado primordial del Estatuto es, precisamente, el jurídico-constitucional. En todo caso, y a los efectos que importan, la sentencia deja claro que el fundamento de la autonomía catalana está en la Constitución, no en la Nación catalana, ni en los derechos históricos del pueblo catalán.

\section{JAVIER GARCÍA RoCA}

Reseñaré la jurisprudencia y expresaré mi opinión al respecto. La STC 31/2010 (F.J. 7 a 11) recuerda que los preámbulos de las leyes no tiene valor normativo y es incorrecto hacerlos objeto directo de una acción de inconstitucionalidad. Ahora bien, se dice que «carencia de valor normativo no equivale a carencia de valor jurídico» y por ello los 
preámbulos no son inaccesibles a los pronunciamientos de la jurisdicción constitucional. Desde la STC 36/1981, se ha mantenido que tienen un valor como interpretación cualificada de las normas, pues expresan las razones en que el propio legislador fundamenta su acción legislativa. Pero esta interpretación — se concluye — nunca podrá imponerse a la autoridad del Tribunal Constitucional como intérprete supremo de la Constitución.

Desde esta lógica, se revisan varios párrafos del preámbulo después formalizados en artículos. No se considera inconstitucional la referencia al «derecho inalienable de Cataluña al autogobierno», en relación con el artículo 1 EAC, ya que debe entenderse dentro del derecho reconocido y garantizado en el artículo $2 \mathrm{CE}$ a las nacionalidades y regiones. Tampoco es inconstitucional afirmar que «los poderes de la Generalidad emanan del pueblo de Cataluña (artículo 2.4 EAC), pues la propia Comunidad de Cataluña trae causa en Derecho de la Constitución española y de la soberanía nacional (artículos 1.2 y 2 CE), y no existe un fundamento distinto del autogobierno, ni el pueblo de Cataluña, como referencia de legitimidad democrática, es expresión de un sujeto distinto en competencia con la única soberanía nacional que se atribuye al «pueblo español». Ambos pronunciamientos me parecen constitucionalmente adecuados.

Respecto de los derechos históricos del pueblo catalán (artículo 5 EAC) como fundamento del autogobierno según el preámbulo y a su actualización «al amparo del artículo 2 y la Disposición Transitoria Segunda y otros preceptos de la Constitución», se hace una sentencia interpretativa de rechazo. Se sostiene que se trata de derechos históricos en un sentido bien distinto del que corresponde a los territorios forales a que se refiere la Disposición Adicional Primera de la Constitución, que hace relación a tradiciones de Derecho privado o público recogidas en la citada transitoria. Sólo en este sentido y reconociendo que no entraña un fundamento distinto del autogobierno de Cataluña al margen de la Constitución, pueden estimarse constitucionales.

Es una afirmación importante que debería permitir rechazar ulteriores demandas del sistema de cupo o concierto económico. Unos privilegios forales con un origen histórico que la Constitución (Adicional $1^{\text {a }}$ ) sólo reconoce a los territorios forales, condición que no cabe reconocer a Cataluña en el marco de la Transitoria $2^{\mathrm{a}}$. Existen sistemas alternativos, como son los mecanismos de compensación interterritorial y de solidaridad financiera, que permiten alcanzar resultados equilibrados y justos del sistema de financiación de Derecho común y responder a las aspiraciones de esa Comunidad. El debate sobre el concierto, sin embargo, ha estado presente en la campaña electoral al Parlamento de Cataluña en el 2010, y al asunto debería dársele una respuesta pragmática y basada en la lealtad constitucional sin seguir practicando arriesgados juegos de ingeniería constitucional.

En relación, con los conceptos de «ciudadano» y «ciudadanía» del artículo 7 EAC referidos a la condición política de catalanes, el Tribunal vuelve a hacer una sentencia interpretativa de rechazo, aclarando que no pueden entenderse por oposición a la ciudadanía española y como una condición distinta al pueblo español. No es sino una especie del género «ciudadanía española» a la que «no puede ontológicamente contradecir» (F.J. 11). De nuevo estimo que la decisión estaba cantada. Acaso pudo expresarse además que ciudadano es quien participa en las comunidades de distintos niveles que el artículo 137 CE determina, organizando lo que he llamado un Estado de tres términos.

A partir de aquí comienzan los problemas. Se impugnaban los términos «nacionales» relativos a los símbolos (artículo 8 EAC) en relación con la afirmación del preámbulo 
sobre la condición nacional de Cataluña proclamada en su momento por el Parlamento catalán. El Tribunal admite que el término «nación» es extremadamente proteico y se desenvuelve en diferentes contextos con ideas y significados distintos, pero declara con firmeza que la Constitución no conoce otra que la Nación española (artículo 2 CE) con la que se cualifica la soberanía ejercida por el pueblo español (artículo 1.2), y remarca «la indisoluble unidad de la nación española» proclamada en el artículo 2 CE. La referencia del artículo $8 \mathrm{EAC}$ a los símbolos nacionales podría inducir a confusión si pretendieran extraerse del preámbulo determinadas consecuencias de la declaración del Parlamento sobre una nación catalana. Sin embargo, cabe interpretar conforme a la Constitución que esos símbolos nacionales se predican de una «nacionalidad» constituida como Comunidad Autónoma. Pero es menester privar de alcance jurídico interpretativo a esas referencias: los términos «nación y nacional» referidos a Cataluña en el preámbulo carecen de eficacia jurídica interpretativa. Una declaración interpretativa que se lleva al fallo, así como la interpretación conforme del artículo 8.

¿Qué decir? La mayor parte de las afirmaciones del Tribunal rechazan estas impugnaciones con buena lógica y me merecen un juicio positivo, pues la demanda del recurso era en esta parte puntillosa. Pero los demasiado adustos razonamientos, malhumorados en la forma y estilo, y muy rígidos en el fondo, sobre las ideas de nación y nacionalidad me temo hayan creado más problemas que los que resuelven y estimo que debieron redactarse de otro modo y con otro espíritu.

A mi entender, el déficit principal de la sentencia es político — en el sentido de conformador de una comunidad estatal - y ello podría haber llevado a oscurecer la fuerza argumental de los más técnicos razonamientos ulteriores en la Comunidad demandada. En las primeras páginas (FF.JJ. 7 a 14) falta una mayor sensibilidad constitucional hacia los símbolos y conceptos políticos y, en consecuencia, capacidad de integración, que es la función principal de cualquier jurisdicción constitucional ${ }^{20}$. No se atina a compaginar en equilibrio la insistencia en la indisoluble unidad de la nación española y su soberanía con otras nociones, no menos constitucionales. Primero, una visión pluralista de esa nación, fundada en el artículo 2 CE y en nuestra configuración histórica como una unión de viejos reinos, y apoyada en la expresión «nacionalidades» que está dotada de una amplia capacidad de autoidentificación: una gran nación española formada por nacionalidades culturales. Segundo, en el vínculo recíproco que entraña la solidaridad —a la que ni siquiera se aludecomo específica forma bilateral y pluralista de comprender dicha unidad política y la propia bilateralidad. Y, por último, en la consideración de la autonomía como derecho al autogobierno. Alguna de estas cuestiones se apunta en el Voto particular del Magistrado Gay.

No hubiera venido nada mal releer el Diario de Sesiones para recuperar el espíritu de generoso compromiso de nuestros padres constituyentes y renovar eso que en otros sistemas se llama el pacto o equilibrio federal ${ }^{21}$. La sentencia no acierta a exponer, con espí-

20 La idea estaba en R. SMEND y en el primer discurso como Presidente del Tribunal Constitucional de M. García Pelayo, puede leerse en Javier García Roca: «La experiencia de veinticinco años de jurisdicción constitucional en España» en La reforma del Tribunal Constitucional, P. PÉrez Tremps (coord.), Tirant lo Blanch, Valencia, 2007, pp. 17-120.

21 Me he ocupado hace cinco lustros de esta forma pluralista y pactista de los constituyentes de entender la unidad y la nación española sobre el reconocimiento de las nacionalidades y la solidaridad. Vid J. GARCía 
ritu conciliador, el valor pluralista del concepto de «nacionalidad», como compromiso constituyente, ni a explicar el pluralismo cultural, histórico y lingüístico en que se funda la nación española. El Tribunal debería haber hecho un mayor esfuerzo hermenéutico e integrador y recuperar mediante una interpretación originaria la buena voluntad de los padres constituyentes que las dificultades pueden haber hecho perder a algunos por el camino. Este déficit político lastra la capacidad suasoria en Cataluña de muchos de los buenos razonamientos jurídicos posteriores.

\section{LuCiano Parejo Alonso}

Con independencia del debate doctrinal sobre su naturaleza, es claro que la finalidad de los preámbulos o exposiciones de motivos de las normas se agotan en la justificación y explicación de éstas y la descripción de su contenido verdaderamente prescriptivo. No integran la decisión que ordena, permite (incentivándolo o desincentivándolo) o prohíbe algo, pero forman parte de ella (si se quiere, por emplear un símil con los actos concretos del poder público, a título de motivación). Lo que significa —a mi juicio- que no son susceptibles de una valoración jurídica con independencia de la correspondiente decisión prescriptiva, siéndolo solo a través y en la que merezca esta última.

El Tribunal Constitucional se pierde aquí, de nuevo, en sus propias disquisiciones generales, que luego no puede aplicar o no aplica siempre de modo consecuente a la hora del examen de los textos concretos. Tras sutiles distinciones - sobre la base de la que media entre norma y preámbulo- entre valor jurídico ${ }^{22}$ y valor normativo o "preceptivo» $^{23}$, de un lado, e idoneidad para ser objeto directo y principal de recurso y accesibilidad al enjuiciamiento de inconstitucionalidad a título de objeto accesorio de dicho recurso ${ }^{24}$, de otro, acierta, no obstante, al señalar que el valor atribuible al preámbulo únicamente juega formando «bloque» con la norma propiamente dicha. Pero inmediatamente anula esta clarificación decisiva al:

Roca: Contribución al estudio de la forma territorial del Estado español, Editorial de la Universidad Complutense, Madrid, 1985, y en diversos trabajos posteriores sobre la solidaridad. De la «gran nación» española, tan grande como para contener sin destruirse una pluralidad de nacionalidades y regiones, habló en las Cortes constituyentes el ponente Herrero de Miñón, quien excluía toda posibilidad de separatismo legal, puesto que conoce un sólo sujeto de autodeterminación, pero al lado reconoce un principio de autoidentificación «de aquellos hechos diferenciales con conciencia de su propia e infungible nacionalidad» (p. 331 y ss). También Arias Salgado quien se refirió al término nacionalidades como una «satisfacción racional» a las reivindicaciones nacionalistas en aras a la integración en la unidad política que es España de «comunidades de acusada personalidad cultural e histórico política» y para lograr una Constitución que sea aceptada por la mayoría de los españoles «un texto constitucional que fuese rechazado o escasamente votado en...Cataluña...nacería con un delicado vicio de origen». $\mathrm{Y}$ otros muchos constituyentes que no es posible reproducir aquí.

22 Predicable tanto de la norma como al preámbulo.

23 Predicable solo de la norma, pues el preámbulo tiene solo el calificado de «interpretativo»; valor este último, al que otorga «especial significación» y conceptúa como «cualificado criterio hermenéutico»

24 La distinción directo-accesorio por lo que hace al objeto del recurso de inconstitucionalidad no sirve para ampliar éste. Lo accesorio o forma parte del objeto o cae fuera de él; no hay tercera posibilidad. Precisamente por ello, el pronunciamiento sobre el preámbulo se integra en el relativo al precepto o preceptos a cuyo contenido se refiera, confundiéndose con él. 
a) Efectuar una distinción, sobre perturbadora e inútil, artificial: la que media entre destinatario específico del preámbulo (el intérprete) y el destinatario obligado por la norma ${ }^{25}$.

b) Posibilitar — gracias a la contradictoria admisión de la incorporación, a título de accesoriedad, del contenido del preámbulo al objeto del recurso ${ }^{26}$ - pronunciamientos propios directos e independientes sobre dicho contenido para evitar que la «interpretación legislativa» se pueda imponer a la establecida, desde su propia autoridad (privativa y excluyente), por el Tribunal Constitucional.

De este modo se hace posible — a la hora del examen del cuestionamiento de párrafos del preámbulo por referirse a conceptos y categorías que pudieran significar la afirmación de un fundamento y un alcance de la norma estatutaria incompatibles con su subordinación a la Constitución — tanto la afirmación de que el pronunciamiento sobre la utilización de tales conceptos y categorías ha de tener lugar al hilo del examen de su formalización en preceptos concretos, como la de que tal pronunciamiento puede conducir, caso de implicar aquella utilización una interpretación constitucionalmente inadmisible, a una privación al preámbulo «en este punto» (¡sic!) del valor jurídico que le es propio (el de interpretación cualificada) sin afectar por ello al precepto sobre el que se proyecta. Concatenación de afirmaciones, en la que ni la segunda se sigue de la primera, ni ésta presta fundamento a aquélla.

El segundo paso, sobre ser inconsecuente con la consideración del conjunto preámbulo-norma prescriptiva como «bloque», no casa con la técnica de la interpretación conforme pródigamente empleada en la Sentencia. Una de dos: o el «bloque» formado por el o los preceptos legales correspondientes y el o los textos del preámbulo traídos a colación «al hilo del examen» de los mismos es insusceptible de una interpretación conforme con la Constitución, por ser el preámbulo determinante del sentido de lo prescrito, en cuyo caso lo único que procede es la declaración de inconstitucionalidad del precepto o preceptos objeto de examen, o admite una interpretación conforme con la Constitución, incluso por ser la proyección del preámbulo en éstos inespecífica o no concluyente, en cuyo caso no procede aquel pronunciamiento. Pues, a pesar de la objetivación de la norma legal una vez promulgada, su parte prescriptiva está establecida precisa y únicamente por las razones y con las finalidades expresadas en el preámbulo, de suerte que la interpretación de la misma es indisociable de éste. La interpretación privativa y excluyente del Tribunal Constitucional puede y debe ciertamente imponerse, pero respecto del expresado bloque y para la depuración del ordenamiento infraconstitucional, id est de lo prescrito por éste. Cualquier otra alternativa supondría un salto cualitativo inaceptable, pues equivaldría a convertir el Tribunal Constitucional, vía técnica

25 El destinatario de la norma es único y la interpretación forma parte del proceso de aplicación de la norma. La diferenciación del «intérprete del preámbulo» solo es posible en términos ideales referidos a uno de los momentos de la aplicación de la norma o, todo lo más, a una pura operación intelectual irrelevante para el Derecho positivo y su efectividad.

26 Es contradictoria, porque choca frontalmente con la negación al preámbulo, en el plano sustantivo, de valor normativo y la afirmación de que el valor interpretativo solo opera en conjunción con el normativo. Lo que significa: discrepancia entre los dos niveles del razonamiento del Tribunal Constitucional, el sustantivo y el procesal, con infracción de la circunscripción constitucional del proceso de inconstitucionalidad a la correspondiente norma legal. 
de la interpretación conforme, de legislador negativo en legislador positivo, de guardián de la Constitución en superior del legislador. Podría, en efecto, hacer de un precepto establecido con finalidad, es decir, sentido y alcance determinados precisamente por el bloque preámbulo-norma otro distinto no imputable al legislador mediante la invalidación de la voluntad expresada por éste y la validación de un mandato no reconducible directamente a ella.

De hecho, la Sentencia no desborda, con carácter general y a pesar de su redacción literal, los términos de la alternativa antes expuesta. Al tratar de la referencia del preámbulo al derecho inalienable de Cataluña al autogobierno y por más que luego haga una desestimación sólo de «la impugnación de la expresión», determina su sentido y alcance por relación y en sede de los establecidos para el artículo 1 del Estatuto. Lo que le permite, de seguido, concluir la constitucionalidad precisamente de los artículos 2.4, 5 y 7 de éste ${ }^{27}$ (adviértase: no de los puntos afectados del preámbulo mismo).

El desbordamiento se produce solo, significativamente, a propósito del empleo por el preámbulo — en combinación con una referencia a determinada declaración del Parlamento catalán— de los términos «nación»y «realidad nacional». El arranque del razonamiento de la Sentencia, tras apartar del examen el elenco de dimensiones distintas a la jurídico-constitucional del proteico término nación, fuerza ${ }^{28}$ su dirección hacia la conclusión que alcanza mediante la asunción implícita de un sentido unívoco de la dimensión jurídico-constitucional del término que permite sostener la inadmisibilidad de cualquier equívoco e, incluso, inducción a equívoco en el ordenamiento respecto de la indisoluble unidad de la nación española. Pero si esto es así, lo consecuente habría sido la declaración de inconstitucionalidad del artículo 8 del Estatuto de Autonomía, que, en línea clara de continuación en este punto del preámbulo, califica de nacionales los correspondientes símbolos de Cataluña. Porque, existiendo — según la lógica de la Sentenciauna relación directa entre la utilización por el preámbulo del término nación y el expresado precepto estatutario, la inadmisibilidad de la inducción a equívoco que procede del primero no puede dejar de contaminar el calificativo «nacional» empleado por el segundo; tanto más, cuanto que, en esta ocasión, el propio Tribunal enfatiza la «especial significación» del preámbulo. El consecuente embarazo del discurso desarrollado por la Sentencia aflora con toda crudeza en la alambicada y contradictoria conclusión, que, además, incurre en el riesgo antes señalado.

Es alambicada la conclusión, porque — separando los pronunciamientos sobre el preámbulo y el precepto estatutario - separa también las coordenadas interpretativas de uno y otro: mientras el preámbulo no es conciliable con la norma fundamental «en atención al sentido terminante del art. 2 CE», el precepto es compatible con ella porque, considerado en si mismo (¡sic!), su sentido está referido exclusivamente a Cataluña «definida como nacionalidad» e integrada en la «indisoluble unidad de la nación española». Y

27 Lo mismo sucede, a propósito del segundo de los preceptos estatutarios citados con la referencia del preámbulo a los derechos históricos del pueblo catalán y la posición singular de la Generalitat.

28 La fuerza porque, sobre no justificar cual sea el sentido unívoco que implícitamente se asume, prescinde de toda argumentación de la exclusión radical por éste de cualquier utilización del término nación en un Estatuto de Autonomía y por relación a la colectividad por éste institucionalizada, incluida una capaz de ser compatible con la indisolubilidad de la nación española y a radicación exclusiva de la soberanía, por tanto, en el pueblo español. 
es contradictoria con el propio razonamiento conducente a ella, porque —en contraste con la radical exclusión de cualquier interpretación conforme- deja en la ambigüedad la privación al preámbulo de su valor propio al efectuarla con un enigmático «sin perjuicio» de la legitimidad (cabida en el ordenamiento) de la nación en términos de autorrepresentación de una colectividad como una realidad nacional en sentido ideológico, histórico o cultural perfectamente legítima, es decir, en un plano distinto al estrictamente jurídicoconstitucional en el que se mueve el artículo 2 CE.

Y, finalmente, bordea los límites de la jurisdicción del Tribunal Constitucional al afirmar la validez y, por tanto, la vigencia del artículo 8 del Estatuto en unos términos que, según él mismo, no se corresponden con la finalidad, el sentido y el alcance con los que fue establecido por el legislador estatutario.

En suma, en este punto el Tribunal Constitucional no ha cumplido adecuadamente su función de depuración del ordenamiento jurídico, pues — dada la estrecha relación entre preámbulo y prescripción estatutarios - sólo eran posibles dos pronunciamientos sobre el bloque formado por ambos: o era inconstitucional por no ser susceptible de una interpretación conforme con la norma fundamental o era constitucional por serlo. Lo que no parece de recibo es la tercera vía seguida, que — gracias a la separación de los elementos del expresado bloque- opera el milagro de la simultánea inconstitucionalidad y constitucionalidad del Estatuto (lo primero en su preámbulo y lo segundo en su art. 8, con el contenido a él atribuido por el propio Tribunal Constitucional).

3. ¿Nos puede emitir su opinión sobre los pronunciamientos de esta Sentencia acerca de la cooficialidad lingüistica?

\section{ROBERTO BLANCO VALDÉS}

Este sí era, y es, a mi juicio, uno de los temas esenciales del Estatuto, pues afecta, como pocos a los derechos de cientos de miles de personas. Lo primero que deseo poner de relieve es que el Estatuto viene en gran medida a dar cobertura estatutaria a una práctica legislativa y reglamentaria, en materia de lengua, que fue construyéndose, tanto en Cataluña como en otras Comunidades con lengua coooficial, a partir del desconocimiento absoluto del principio de cooficialidad lingüística previsto en la Constitución, principio que las llamadas políticas de normalización lingüística han vulnerado de forma grave y reiterada. Esta aclaración inicial me parece necesaria por dos motivos. En primer lugar, porque el TC fija un principio de partida sobre la significación constitucional de la cooficialidad lingüística que entiendo es plenamente coherente con nuestra ley fundamental; pero, también, en segundo lugar, porque el propio TC ignora luego, a la hora de juzgar sobre la constitucionalidad de los preceptos impugnados en el recurso del PP, tanto su propio principio de partida como una realidad fáctica que, según parece evidente, debería haber sido tenido en cuenta por el Tribunal para decidir sobre la compatibilidad o no con la Constitución de determinados preceptos estatutarios.

El aludido principio de partida del TC, con el que concuerdo plenamente, es el de que el carácter del catalán como lengua propia, que predica el Estatuto, «no puede suponer un desequilibrio del régimen constitucional de ambas lenguas en perjuicio del 
castellano». Era esperable, entonces, que, en coherencia con tal doctrina, el Tribunal hubiera procedido a anular los preceptos que tenían por finalidad establecer un claro desequilibrio al respecto a favor del catalán y, de manera muy especial, el artículo $6^{\circ} .1$, que disponía que «la lengua propia de Cataluña es el catalán. Como tal el catalán es la lengua de uso normal y preferente de las Administraciones Públicas y de los medios de comunicación públicos de Cataluña, y es también la normalmente utilizada como vehicular y de aprendizaje en la enseñanza». Pero el TC no hizo tal cosa sino sólo declarar inconstitucional el termino «y preferente» del citado precepto, así como someter a interpretación constitucionalmente adecuada otros artículos que disponen de forma taxativa lo contrario de lo que el TC les hace decir a través de su interpretación: el apartado 2 del artículo $5^{\circ}$ (relativo a la naturaleza de las lenguas oficiales en Cataluña), el apartado 5 del artículo 33 (que otorga a los catalanes el derecho a relacionarse en catalán con los órganos constitucionales y jurisdiccionales de ámbito estatal), el artículo 34 (que regula el llamado deber de disponibilidad lingüística, por virtud de cual todas las personas tienen derecho a ser atendidas oralmente y por escrito en la lengua oficial que elijan en su condición de usuarios o consumidores), los apartados 1 y 2 del artículo 35 (relativos a los derechos lingüísticos en la enseñanza) y el apartado 5 del artículo 50 (relativo al fomento y difusión del catalán). Dado que son muchos preceptos, con un solo ejemplo bastará para explicar el sorprendente y creo que inadecuado proceder del TC: me refiero al llamado deber de disponibilidad lingüística, contenido en el artículo 34 del Estatuto, que constituye, sin duda, una de las previsiones estatutarias en que con más claridad se pone de relieve la técnica ya citada de salvar la constitucionalidad de una disposición sobre la base de hacerle decir juntamente lo contrario de lo que afirma abiertamente. La finalidad del precepto era imponer un deber de disponibilidad lingüística a las entidades, empresas y establecimientos abiertos al público en Cataluña, deber respecto al cual el TC sienta una doctrina inobjetable: que ese deber «no puede significar la imposición a estas, a su titular o a su personal de obligaciones individuales de uso de cualquiera de las dos lenguas oficiales de modo general, inmediato y directo en las relaciones privadas, toda vez que el derecho a ser atendido en cualquiera de las dos lenguas sólo puede ser exigible en las relaciones entre los poderes públicos y los ciudadanos. Por ello, en este ámbito de las relaciones entre privados no cabe entender que el Estatuto imponga de un modo inmediato y directo tal obligación a los ciudadanos. Interpretado en estos términos, el art. 34 - concluye el Tribunal- no es contrario a la Constitución». La indisimulable voluntad de no declarar inconstitucional el precepto lleva al TC a sentar como interpretación válida del mismo la que en ningún caso cabe extraer del tenor literal de un artículo que dispone precisamente lo contrario de lo que el Tribunal acepta como constitucional y que prescribe precisamente y únicamente lo que aquel proclama contrario a la Constitución. Resulta así, en conclusión, que el Tribunal utiliza, de un modo claramente desviado, la técnica de la interpretación conforme, no para elegir o excluir una o más de las posibles interpretaciones de un determinado precepto (o parte de él) sino para declarar constitucionales artículos que establecen lo contrario de lo que el TC estima constitucional mediante la formula de hacerles decir lo que el Tribunal estima que deben decir aunque lo que dispongan sea justamente lo contrario.

Sea como fuere, lo cierto es que algunos pronunciamientos del TC en materia lingüística (sobre todo el de que «el castellano, no puede dejar de ser también lengua 
vehicular y de aprendizaje en la enseñanza») han acabado por producir, como era de esperar, unos efectos que superan los límites del debate sobre la constitucionalidad del Estatuto catalán, al haber servido de base al Tribunal Supremo para dictar, a finales del año 2010, varios fallos en los que abren una clara brecha en la legitimidad constitucional de la legislación que ha llevado a que en Cataluña el castellano haya desaparecido como lengua vehicular de la enseñanza primaria y secundaria.

\section{Raúl Canosa Usera}

El Tribunal Constitucional declara inconstitucional la preferencia que el artículo 6.2 EAC daba a la lengua catalana pero considera legítima una política de promoción del idioma históricamente postergado. Interpreta asimismo otros preceptos estatutarios (arts. 33.5 , 34, 35, 50) y su interpretación la lleva al fallo, para aquilatar el deber de conocimiento del catalán en relación con el deber de disponibilidad lingüística que puede exigirse de los poderes públicos pero no individualmente a los particulares. También asegura que el castellano podría ser lengua vehicular de la enseñanza.

Los pronunciamientos sin duda van en la línea de afirmar la cooficialidad, no sólo nominal, del castellano en Cataluña. Habrá que llegar a un punto de equilibrio entre la promoción del catalán que la sentencia legitima y la preservación del castellano que evitara su arrinconamiento.

La STC 31/2010 ya ha tenido repercusión con la anulación judicial de una norma del Ayuntamiento de Barcelona que imponía el uso administrativo exclusivo del catalán, y podrían en el futuro suscitarse nuevos conflictos. Queda claro también en materia lingüística que la preferencia jurídica del catalán o su exclusiva oficialidad sólo cabrían en una Constitución reformada.

\section{FranCESC DE CARRERAS SERRA}

Numerosos artículos del Estatuto están dedicados a regular materias referidas a la lengua. No cabe duda que la voluntad del proyecto aprobado por el Parlamento de Cataluña era incorporar al Estatuto los principios clave de la Ley de Política Lingüística de 1998, ley que no había pasado el filtro del Tribunal Constitucional, con el fin de blindar dichos principios al amparo del Estatuto, con la convicción de que el Tribunal no se atrevería a declarar preceptos inconstitucionales en esta delicada materia. Sin embargo, el tiro les ha salido por la culata. Como es lógico, el Tribunal ha aplicado a las normas estatutarias su jurisprudencia en la materia, especialmente la que se desprende de las SSTC 82/1986 y 337/1994, y vía nulidad, interpretación en el fallo o simple interpretación en los fundamentos, ha alterado la legislación vigente, lo cual deberá comportar una profunda modificación de la política lingüística catalana. En efecto, esta legislación deberá acomodarse a la doctrina de la sentencia y pasar del actual monolingüismo de facto de los poderes públicos en Cataluña a un bilingüismo que sea acorde con las previsiones constitucionales establecidas principalmente en el art. 3 CE y con la realidad sociolingüística catalana. Estos son los principios básicos emanados de la sentencia. 
a) Catalán y castellano son las lenguas oficiales de todos los poderes públicos radicados en el territorio autonómico, incluidos los órganos de la Administración central y de otras instituciones estatales. Ambas lenguas son de uso normal por y ante estos poderes públicos. Además, deben estar situadas en posición de "perfecta igualdad de condiciones por cuanto hace a las formalidades y requisitos de su ejercicio, lo que excluye que haya de pedirlo expresamente», tal como hace el último inciso del art. 50.5 EAC, precepto que a mi juicio hubiera debido ser declarado nulo y que es objeto de una forzada interpretación conforme (FJ-23). Además, el catalán no puede ser de uso «preferente» respecto al castellano porque ello supondría la primacía de una lengua sobre otra, es decir, recibir un trato privilegiado contrario a la igualdad de las lenguas cooficiales. Por esta razón, el art. 6.1 EAC, en cuanto determina el «uso preferente» del catalán como lengua oficial ha sido declarado nulo.

b) El catalán puede ser lengua vebicular y de aprendizaje en la enseñanza pero no la única que goce de tal condición, predicable con igual título del castellano en cuanto es también lengua oficial en Cataluña. No obstante, sentado este principio en el FJ-14 y reiterado con más detalle en el FJ-24, no se comprende que no sea declarado inconstitucional y nulo el art. 35, en sus apartados 1 y 2 (premier inciso), en virtud de la regla hermenéutica inclusio unius, exclusio alterius. En efecto, tales preceptos dicen así. Art. 35.1: «Todas las personas tienen derecho a recibir la enseñanza en catalán, de acuerdo con lo establecido por el presente Estatuto. El catalán debe utilizarse normalmente como lengua vehicular y de aprendizaje en la enseñanza universitaria y en la no universitaria». Art. 35.2, primer inciso: «Los alumnos tienen derecho a recibir la enseñanza en catalán en la enseñanza no universitaria».

c) El deber de conocer el catalán sólo es aplicable a aquellas personas relacionadas con los ámbitos de la educación y de las administraciones públicas. Por tanto, no tiene el carácter generalizado del deber de conocimiento del castellano establecido en el art. 3 CE. Así debe interpretarse el significado de tal deber exigido en el art. 6.2 EAC, en una interpretación muy forzada, contraria a la literalidad de la norma.

d) Los ciudadanos tienen el derecho de opción lingüística —entre castellano y catalán- para relacionarse con los poderes públicos y, por tanto, pueden escoger libremente la lengua en la que a ellos se dirigen. Los poderes públicos, a su vez, tienen la obligación de atender a los ciudadanos en la lengua oficial que ellos elijan. Por tanto, el personal al servicio de las Administraciones radicadas en Cataluña debe acreditar un conocimiento adecuado y suficiente de las dos lenguas oficiales para ejercer las funciones propias de su cargo o puesto de trabajo. En cambio, en las relaciones entre particulares, como se dice al examinar el art. 34 en el FJ-22, no es exigible el derecho a ser atendido en cualquiera de dichas lenguas dado que en estos casos el derecho de opción lingüística de una parte no tiene como correlato ningún deber por parte de la otra parte al no ser ninguna de ellas poderes públicos, únicos obligados a usar indistintamente ambas lenguas cooficiales. Es por ello que hubiera debido ser declarado nulo este art. $34 \mathrm{EAC}$ en lugar de ser objeto de una confusa interpretación que, por lo que parece deducirse, es contraria a la literalidad del texto.

e) El criterio territorial delimita la oficialidad del uso de una lengua por parte de los poderes públicos. Por tanto, la sede geográfica de un órgano estatal determina la lengua oficial en la que deben dirigirse a él los ciudadanos. Esta es la doctrina general del TC en 
este punto (STC 82/1986), ratificada en esta sentencia. El art. 33.5 EAC determina que los ciudadanos de Cataluña tienen derecho a relacionarse por escrito en catalán con los órganos constitucionales y jurisdiccionales de ámbito estatal de acuerdo con la legislación correspondiente. La sentencia considera que la legislación estatal puede adecuarse o no, con entera libertad, a este precepto e, interpretado en este sentido, el art. 33.5 EAC es declarado constitucional. A mi modo de ver, esta interpretación, contraria a la literalidad del precepto, exigía precisamente que tal precepto fuera declarado inconstitucional y nulo.

De este conjunto de principios, que en su mayoría no son más que reiteración de doctrina anterior del Tribunal, se llega a las siguientes conclusiones: 1) la cooficialidad lingüística exige que el bilingüismo debe ser operante en las instituciones públicas y en la enseñanza; b) el deber de conocer el catalán no alcanza a todos los ciudadanos de Cataluña sino solo a aquellos que estén obligados a ello por la función que desempeñan en las Administraciones Públicas o por otras normas específicas; c) es contrario a la Constitución el llamado deber de disponibilidad lingüística de entidades, empresas y establecimientos abiertos al público; por tanto, es inexistente el deber de usuarios y consumidores a ser atendidos en la lengua oficial que elijan; d) el estatuto no es la norma adecuada para conferir a los ciudadanos de Cataluña el derecho a dirigirse en catalán a los órganos constitucionales y jurisdiccionales de ámbito estatal.

Estas conclusiones exigen la modificación del conjunto de la política lingüística catalana, especialmente la emprendida a partir de la Ley de Política Lingüística de 1998.

\section{Marc CARrillo López}

Acerca del régimen lingüístico, la sentencia ha decidido la inconstitucionalidad del art. 6.2 EAC y ha emitido un fallo de carácter interpretativo en los artículos 6.2, 33.5, 34, 35 y 50. En el primer caso, rechaza que el carácter del catalán como «lengua de uso normal y preferente de las administraciones públicas y de los medios de comunicación pública de Cataluña...» pueda ser una característica que pueda ser interpretada como la «mera descripción de una mera realidad lingüistica», que es lo que ha venido siendo en dichos ámbitos, sino que «implica la primacía de una lengua sobre otra» (FJ 14,a), estableciendo un uso prioritario del catalán. Por tanto, ello habría de significar que las administraciones han de utilizar simultáneamente ambas lenguas oficiales en su actividad interna y en las relaciones entre si y con respecto a los ciudadanos. Esta interpretación trasciende al texto del Estatuto, puesto que la expresión preferente ya estaba prevista en la vigente Ley 1/1998, de 7 de enero, de Política Lingüústica para referirse al catalán como lengua «preferentemente empleada por la Administración del Estado en Catalunya en la forma que ésta misma determine, por las otras instituciones y, en general, por las empresas y las entidades que ofrezcan servicios al público» (art. 2.2.b). Dicha Ley no fue objeto de recurso pero a la luz de la STC 31/2010 su contenido deberá ser reinterpretado.

Ahora bien, el deber de ese uso simultáneo de ambas lenguas puede verse matizado en la medida en que para el Tribunal no resulta extraño que las lenguas minoritarias como es el caso que sigue afectado al catalán, precisen de medidas positivas de fomento. Por ello señala el legislador está habilitado para adoptar «las adecuadas y proporcionadas me- 
didas de política lingüistica tendentes a corregir, de existir, situaciones históricas de desequilibrio de una de las lenguas oficiales respecto de la otra, subsanando así la posición secundaria o de postergación que algunas de ellas pudiera tener» (FJ 14). Pero, en todo caso en la sentencia queda claro que de la inconstitucionalidad declarada sobre el carácter preferente, no podrá deducirse que una forma de medida de política lingüística de normalización o de fomento destinada a enmendar desigualdades históricas pueda consistir en atribuir el carácter de uso preferente a una lengua, porque ello implica una primacía y un uso prioritario. En consecuencia, de acuerdo con la sentencia, es preciso diferenciar dos planos que no pueden vincularse uno al otro: el primero es el carácter preferente en el uso de una lengua, que como tal queda impedido; el segundo son las medidas adecuadas y proporcionadas para corregir desequilibrios existentes, que en este caso no quedan excluidas.

En el apartado de las decisiones de naturaleza interpretativa, cabe retener la atención el deber de conocer el catalán (art. 6.2 EAC). Era ésta una previsión estatutaria que nacía de la premisa basada en la presunción de conocimiento del catalán adquirido ya por varias generaciones a través de la escuela ${ }^{29}$. El Tribunal interpreta que sería inconstitucional la pretensión de imponer un deber de conocimiento del catalán equivalente al que se desprende del deber constitucional de conocimiento del castellano; pero no se trataría de eso sino que, en realidad, lo previsto en el Estatuto no significa «de un deber generalizado (...), sino de la imposición de un deber individual y de obligado cumplimiento que tiene su lugar específico y propio en el ámbito de la educación (...) y en el de las relaciones de sujeción especial que vinculan a la Administración catalana con sus funcionarios, obligados a dar satisfacción al derecho de opción lingüística» (FJ 14). En consecuencia, lo que interpreta el Tribunal es que no existe un deber de conocimiento del catalán paralelo al del castellano, salvo en éstos dos ámbitos. Pero con esta conclusión pretendidamente interpretativa, el Tribunal lo que en realidad hace es mutar el sentido del art- 6.2 del Estatuto ${ }^{30}$.

Por lo que se refiere al ejercicio de derechos lingüísticos ante las administraciones públicas y las instituciones estatales (art. 33), así como el fomento y la difusión del catalán (art. 50), el Tribunal adopta también una decisión interpretativa. Así en relación al derecho a relacionarse por escrito en catalán con las instituciones del Estado, el Estatuto remite a lo que establezca la ley que no puede ser otra que la estatal, lo cual por sí mismo ya debería haber excluido mayores precisiones por parte del tribunal. Porque en realidad de lo que se trata no es de un derecho sino de un principio impulsado por el Estatuto, como ocurre en otros supuestos de preceptos estatutarios de densidad normativa menor, cuya eficacia no depende del ejercicio de potestades normativas atribuidas a la Generalitat. En este caso, al tratarse de una competencia del Estado es éste quien goza de la plena capacidad de decisión para adoptarlo. De todas formas, el Tribunal señala que el reconocimiento de este derecho en ningún caso supone ninguna declaración de extraterritorialidad del catalán.

29 Jou Mirabent, L., «L'oficialitat lingüística, un concepte jurídic» (discurs d'ingrés). Acadèmia de Jurisprudència i Legislació de Catalunya, Barcelona, págs. 46-50

30 Milian I Massana, A., «El règim de les llengües oficials. Comentari a la sentència del Tribunal Constitucional 31/2010, de 28 de juny». Revista Catalana de Dret Públic (Especial Sentència sobre l'Estatut). Edición Electrónica, 2010 (http://www,rcdp.cat). 
Sin embargo, transcurridos los cuatro años de vigencia del Estatuto de 2006 el Estado no se ha dado por aludido al respecto, incluso cuando tenía una buena oportunidad para hacerlo respecto del personal de la Administración de Justicia con motivo de la reforma de la LOPJ a través de la L.O. 1/2009, de 3 de noviembre. Pero en esta última reforma, la cuestión de la lengua ha pasado desapercibida. Como también ha sido obviada por la STC 31/2010 la interpretación adoptada por la STC 56/1990 (FJ 46) acerca de los requisitos lingüísticos previstos en los estatutos de autonomía respecto de la relación entre Estatuto y Ley orgánica, donde se establecía que ambos «configuran una normación compuesta que, lejos de excluirse recíprocamente, se complementan».

En lo que respecta al fomento y difusión del catalán en el ámbito de la Administración pública autonómica (art. 50.5 EAC), en las empresas que de ella dependen y los concesionarios de sus servicios, el Tribunal interpreta que la medidas que en este sentido se adopten, no han de suponer ningún impedimento ni carga alguna para el ciudadano que desee recibir en castellano las comunicaciones emitidas por los órganos y entidades con los que se relacione. Por lo que cabe deducir que el Tribunal excluye que sea precisa la solicitud expresa de que la lengua de comunicación sea el castellano.

La sentencia también adopta una resolución interpretativa sobre la regulación de la lengua en el ámbito de la enseñanza. En el primer apartado (segundo inciso) del art. 35 EAC se establece que «El catalán se ha utilizar normalmente como lengua vebicular y de aprendizaje en la enseñanza universitaria y no universitaria». EL Tribunal entiende que este precepto estatutario «no es inconstitucional interpretado en el sentido de que con la mención del catalán no se priva al castellano de lengua vebicular y de aprendizaje en la enseñanza» (FJ 24). Para ello, se apoya en la STC 337/1994 (relativa a la antigua Ley de Normalización Lingiuística de 1983), en la que en atención a ello, juzgó como legítimo que el catalán fuese el centro de gravedad del modelo de bilingüismo adoptado, siempre que ello no comportase «la exclusión del castellano como lengua docente de forma que quede garantizado su conocimiento y uso en el territorio de la Comunidad Autónoma» (FJ 10). Como no podía ser de otra manera constitucionalmente admisible, el castellano ha de ser al igual que el catalán, lengua de aprendizaje en Cataluña. La cuestión estriba en la intensidad que deba tener el uso como lengua vehicular. La sentencia precisa que «siendo así que ambas lenguas han de ser no sólo objeto de enseñanza, sino también de medio de comunicación en el conjunto del proceso educativo, es constitucionalmente obligado que las dos lenguas cooficiales sean reconocidas por los poderes públicos competentes como vebiculares, siendo en tales términos los particulares titulares del derecho a recibir la enseñanza en cualquiera de ellas» (FJ 24). Sin embargo, resulta más problemática la aplicación práctica de ambas lenguas entendidas como vehiculares, es decir, de uso habitual, pues parece lógico que si lo ha de ser una, no parece que lo haya de ser simultáneamente la otra. Sobre todo si se acepta el modelo de inmersión lingüística adoptado desde los inicios en Cataluña. Con la sentencia ello no queda claro, aunque reconoce acogiéndole a lo establecido en la STC 337/1994 - que «resulta perfectamente legítimo que el catalán, en atención al objetivo de la normalización lingüística en Cataluña, sea el centro de gravedad de este modelo de bilingüismo» (FJ 24). Por todo ello, no está excluido que la indeterminación de la sentencia pueda ser un germen de futuros conflictos jurídicos.

Finalmente, en relación al deber de disponibilidad lingüística en las relaciones interprivatos, el Estatuto establece que los derechos lingüísticos de los consumidores y usuarios 
comportan que todas las personas tienen derecho a ser atendidas oralmente y por escrito en la lengua oficial de su elección en los establecimientos abiertos al público. El Tribunal interpreta que ello es exigible en las relaciones entre ciudadanos y poderes públicos. Ahora bien, la ley que regule del deber de disponibilidad lingüística en las relaciones inter-privatos «no puede significar la imposición a éstas (las empresas) a su titular o a su personal de obligaciones individuales de uso de cualquiera de las lenguas oficiales de modo general y directo en las relaciones privadas...» (FJ 22). Con lo cual, la disponibilidad lingüística en el ámbito privado queda subordinada a la libre decisión del local de negocio lo que enerva las garantías de uso normalizado de la lengua minoritaria. No obstante, en su interpretación el Tribunal parece abrir un resquicio al establecimiento de alguna excepción al respecto. En efecto, el inciso «de modo general y directo en las relaciones privadas...», quizás, podría a modo de mera hipótesis - permitir que la ley estableciese un tratamiento distinto del deber de disponibilidad lingüística en función de las dimensiones del establecimiento abierto al público.

\section{JaVier Corcuera ATIENZA}

La sentencia aborda, finalmente, los excesos de una política lingüística cuya inconstitucionalidad se ha venido obviando en base al argumento de la capacidad de la Generalidad de regular la materia. La falta de coraje de Congreso y Senado, así como del Defensor del Pueblo, para plantear en su día recurso de inconstitucionalidad contra la Ley de Política Lingüística de 1998, ha permitido consolidar prácticas que el Tribunal ha considerado ahora contrarias a la Constitución, pero que no será sencillo erradicar. La sentencia declara inconstitucional el inciso del artículo 6.1 del Estatuto que señalaba que el catalán era la lengua preferente (además de normal) de las Administraciones públicas y de los medios de comunicación públicos de Cataluña: no puede usarse una lengua con carácter preferente pues toda lengua oficial es de uso normal. A partir de ahí plantea una doctrina que me parece impecable: la oficialidad de una lengua no depende de su realidad y peso como fenómeno social, sino de su reconocimiento por los poderes públicos como medio normal de comunicación en y entre ellos y en su relación con los sujetos privados, con plena validez y efectos jurídicos; la definición del catalán como lengua propia no puede suponer un desequilibrio del régimen de cooficialidad en perjuicio del castellano; los ciudadanos residentes en las Comunidades Autónomas con lenguas cooficiales tienen derecho a utilizar ambas en sus relaciones con la autoridad, pero la Administración no puede presumir el conocimiento del catalán por todos, y dirigirse a ellos exclusivamente en dicha lengua; el derecho de los ciudadanos a recibir comunicaciones en castellano no puede obligarles a cumplir formalidades o cargas (cabe pensar que de esto habría de seguirse la obligación de la Administración de generalizar el bilingüismo en sus comunicaciones, incluidos los distintos boletines oficiales).

Por lo que respecta a la educación, el castellano no puede dejar de ser también lengua vehicular y de aprendizaje en la enseñanza. No cabe pretender legítimamente que la enseñanza se imparta única y exclusivamente en una de las dos lenguas cooficiales. Las dos han de ser conocidas, y el Estado ha de garantizar el derecho a conocer el castellano a través de las enseñanzas recibidas en los estudios básicos. 
Finalmente, y obviando otras cuestiones, el derecho de opción lingüística en las relaciones interprivatos y el deber de disponibilidad de las empresas (artículo 34 EAC), es una consecuencia del derecho de opción lingüística, pero no puede suponer deber inmediato, general y directo, quedando diferido su contenido a la ley.

La claridad de la sentencia, y la rotundidad de sus afirmaciones en esta materia contrastan con la práctica seguida hasta ahora por los poderes públicos autonómicos, y su aplicación puede presentar no pocos problemas. No han faltado declaraciones que han puesto en duda la modificación de la política de inmersión lingüística en la educación, y la respuesta a determinadas decisiones judiciales sobre la ausencia de bilingüismo en comunicaciones de las administraciones públicas hace prever que su puesta en marcha tendrá dificultades. A mi entender, las insuficiencias de la técnica de la interpretación conforme se manifiestan particularmente en esta materia, en que es especialmente grave el riesgo de que sobrevivan usos que ignoren la doctrina del TC. No es fácilmente comprensible que el TC no haya declarado la inconstitucionalidad del último inciso del artículo $50.5 \mathrm{EC}$, que señala que habrán de utilizar el catalán las administraciones públicas de Cataluña, las empresas que dependan de ellas, y las concesionarias de sus servicios «en las comunicaciones y las notificaciones dirigidas a personas físicas o jurídicas residentes en Cataluña, sin perjuicio del derecho de los ciudadanos a recibirlas en castellano si lo piden.»Y tampoco expresa la igualdad entre las lenguas cooficiales la mención del artículo 35 a que el catalán deba utilizarse «normalmente como lengua vehicular y de aprendizaje en la enseñanza universitaria y en la no universitaria».

\section{JAVIER García Roca}

Sobre el catalán como lengua propia se fija un estándar muy importante y claro: $c 0$ oficialidad no es preferencia. Asimismo se aclara que el deber de conocimiento del catalán no es un deber individualizado para los ciudadanos sino un mandato a los poderes públicos. Una norma de fines que encuentra su lugar específico en la educación y en los funcionarios. Y se erige el derecho de opción lingüística de los ciudadanos en el eje en torno al cual debe girar el modelo.

Acerca de estas cuestiones (artículos 6 EAC y $3.2 \mathrm{CE}$ ), el Tribunal sienta algunas cautelas muy importantes, probablemente no son nuevas y se fundan en precedentes, pero sí innovadoras por su rotundidad y claridad. La definición del catalán como lengua propia de Cataluña — se dice- no puede suponer un desequilibrio del régimen de cooficialidad de ambas lenguas en perjuicio del castellano. No puede pretenderse que el catalán sea lengua de uso normal y preferente del poder público «siquiera sólo del poder autonómico» (STC 31/2010, F.J. 14); «las Administraciones públicas catalanas... como el poder público estatal en Cataluña no pueden tener preferencia por ninguna de las dos lenguas oficiales». Por eso se declara inconstitucional el artículo 6.1 EAC en el inciso en que se adjetivaba de «preferente» el catalán como lengua de uso normal en Cataluña y en las Administraciones públicas y los medios de comunicación público. Un pronunciamiento a reservar.

En lo que atañe a la imposición estatutaria del deber de conocimiento del catalán (artículo 6.2 EAC) se recuerda (F.J. $14^{\circ}$ ) que no es un «deber constitucional», pues la Cons- 
titución sólo impone el deber general de conocer el castellano como idioma común (artículo 3.1) cuyo conocimiento puede presumirse con independencia de la residencia. No teniendo las Administraciones derecho alguno a dirigirse exclusivamente a los ciudadanos en lengua catalana, tampoco puede presumir en éstos su conocimiento y formalizar esa presunción como deber de conocimiento. Cabe una interpretación conforme a la Constitución del precepto si se entiende como un mandato a los poderes públicos para que adopten las medidas necesarias para facilitar el cumplimiento de ese deber, pero no como un deber individualizado, generalizable y exigible a todos los ciudadanos de Cataluña. La imposición de ese deber — se afirma - tiene su lugar específico en el ámbito de la educación y en el de las relaciones especiales de sujeción y los funcionarios, obligados a dar satisfacción al derecho de opción lingüística. Esta interpretación conforme a la Constitución se lleva por el Tribunal al fallo.

El Tribunal parece arrancar de la posición doctrinal más generalizada sobre la naturaleza de los «deberes constitucionales» (v.gr. Santiago Varela, Giorgio Lombardi y otros), que supone tanto una intensa sujeción de los ciudadanos, restrictiva de su derechos, como una obligación de actuación de los poderes públicos o norma de fines, para elegir únicamente el segundo de ambos contenidos respecto de este «deber estatutario». La decisión es constitucionalmente acertada, pues no hubiera sido legítimo admitir la posibilidad de la imposición de sanciones a los ciudadanos por el incumplimiento de ese supuesto deber. Manejando un sólido argumento cultural, la historia nos demuestra que las lenguas no pueden imponerse por la fuerza sino que deben difundirse mediante la educación y la cultura; como el poeta y patriota catalán Salvador Espriu escribió con elegancia: no se puede despreciar ninguna lengua.

Más controvertido es el pronunciamiento respecto del catalán como lengua de la enseñanza. Se reconoce que el catalán debe ser lengua vehicular y de aprendizaje en la enseñanza, pero no la única que goce de tal condición; el castellano no puede dejar de ser utilizado también como lengua a esos mismos efectos en tanto que lengua asimismo oficial en Cataluña (STC 31/2010, F.J. 14, un pronunciamiento que se reitera en la sentencia del recurso del Defensor del Pueblo). Se descarta pues toda pretensión de exclusividad de una de las lenguas oficiales en materia de enseñanza.

Esta innovación de la sentencia, por la contundencia del pronunciamiento, podría quizás abrir un nuevo conflicto en materia educativa -es pronto para estar seguros-, dada la tradicional comprensión del catalán por los pedagogos en Cataluña y las sucesivas leyes de normalización de la Comunidad como lengua vehicular de la educación con la finalidad de facilitar la integración de todos los alumnos y permitir la normalización progresiva del catalán como lengua oficial en todos los ámbitos. Se trataba de fomentar su uso, habida cuenta del desigual punto histórico de partida del catalán respecto del castellano, rezagado durante siglos como lengua minoritaria. Unas acciones políticas que el propio Tribunal Constitucional había declarado dentro de la Constitución en diversas sentencias. Quizás sea esta la decisión más relevante y la que puede necesitar mayores concreciones y desarrollos legales futuros, según evidencian las posteriores sentencias del Tribunal Supremo que arrancan de la misma y de las que a continuación daré noticia.

La Sala de lo Contencioso Administrativo, Sección Cuarta, del Tribunal Supremo ha iniciado un diálogo judicial con esta STC 31/2010 (F.J. 14º) en sus recientes sentencias de 9, 13 y 16 de diciembre de 2010, -redactadas de manera bastante prolija lo que les hace 
perder tensión argumental-. En ellas se estimaron tres recursos (793, 796 y 1839 de 2009) deducidos por los actores quienes denunciaron en la instancia que toda la educación que se impartía a sus hijos en las enseñanzas obligatorias se hacía exclusivamente en catalán, y habían solicitado previamente a la Consejería de Educación, viendo rechazada su pretensión, que se reintrodujera el castellano como lengua vehicular de forma proporcional en la enseñanza no universitaria.

Esta Sección del Tribunal Supremo estima los recursos de casación presentados, invocando la jurisprudencia constitucional reseñada. En la primera sentencia (ponencia de Santiago Martínez-Vares) se declara probado que los niños afectados aprendieron castellano únicamente como materia de estudio, cumpliéndose las asignaciones de tiempo semanal fijadas en los distintos reglamentos, pero no como lengua vehicular. Una exclusión que la Sección estima «pervierte el modelo de bilingüismo integral o de conjunción lingüística establecido en la Constitución» (con cita de la STC 337/1994, de 23 de diciembre), para introducir una «inmersión lingüística contraria al espíritu y a la letra de la misma» (F. J. $6^{\circ}$ ). La política de normalización del catalán no puede negar la realidad de la convivencia armónica de ambas lenguas cooficiales y privar al castellano de su condición de lengua vehicular; con mayor razón, cuando los estudios sobre el conocimiento del catalán y usos lingüísticos revelan ya altísimos niveles en diversos estratos de población y edades (Ibidem). Desde esta perspectiva, se reconoce que tiene pleno sentido la pretensión de los recurrentes y se estima el recurso. Del mismo tenor es la segunda sentencia.

En la tercera sentencia (ponencia de Celsa Pico) se arranca también de la STC 31/2010 (F.J. 14 $4^{a}$, se reproducen argumentos de la primera, y se reitera que según dicha jurisprudencia constitucional el artículo 35.1 del Estatuto de Cataluña, no es inconstitucional interpretado en el sentido de que no priva al castellano de su condición de lengua vehicular. En consecuencia, ya no puede aceptarse que el catalán sea la única lengua vehicular de la enseñanza, pese a que esa sea la realidad presente en los reglamentos autonómicos discutidos. Esta conclusión no puede refutarse por el hecho de que determinadas materias se impartan en castellano, es decir, como lengua de estudio. Y se pide a la Generalidad que «adopte cuantas medidas sean precisas para adaptar su sistema de enseñanza a la nueva situación» creada por la STC 31/2010 (F.J. $8^{\circ}$ ). Finalmente, se reconoce el derecho del recurrente a que el centro docente le facilite en castellano el correspondiente impreso de preinscripción.

Veremos cómo se da cumplimiento a estas sentencias. Los primeros comentarios muy duros del nuevo Gobierno de la Generalidad parecen agarrarse a la indeterminación del fallo «cuantas medidas sean precisas» y los acuerdos de investidura CiU-PSC apuestan por mantener la inmersión lingüística. A mi modesto entender, pues no soy un especialista en cuestiones lingüísticas, siempre tan delicadas, lo importante debería ser asegurarnos de dos objetivos. De un lado, el buen conocimiento de los niños en las escuelas tanto del catalán como del castellano al finalizar la enseñanza obligatoria, y de la suficiente presencia de ambas lenguas en los planes de estudios (como manda el artículo 35. 2 EAC). Y, de otro, asimilar realmente la riqueza intelectual y cultural que supone para los niños la posibilidad de crecer en la enseñanza y desarrollarse luego como ciudadanos en la sociedad con el manejo simultáneo de dos lenguas que interactúan. Esto es lo que quisieron los constituyentes al proclamar la diversidad de lenguas españolas como un 
rico patrimonio (artículo 3.3 CE). Es un privilegio poder leer a Josep Pla y a Miguel Delibes, cada uno en su propia lengua, y desde luego la mejor forma de entender España y de abrirse al plurilingüismo y al estudio de otras lenguas diferentes a la habitual que nos demanda la integración europea. No sé, con toda sinceridad, si estos razonables objetivos exigen dos lenguas vehiculares, o puede bastar con una para favorecer la integración y asegurarse del conocimiento de un nivel elevado de la otra lengua de estudio como hasta ahora se ha hecho durante décadas. Pero creo que es probablemente una decisión que debería corresponder al legislador democrático, ponderando las experiencias adquiridas, -el autonómico o en algunos extremos el básico-, y que pueden caber diversos modelos lingüísticos en desarrollos legislativos igualmente constitucionales. Lo importante son los resultados y no los medios.

\section{Luciano Parejo Alonso}

Entendiendo que la pregunta se refiere exclusivamente a las consideraciones desarrolladas en relación con las cuestiones calificadas como de principio y no, por tanto, a las —en algún caso más discutibles - dedicadas régimen lingüístico establecido por el Estatuto, debo adelantar mi coincidencia con la Sentencia en este punto, que me parece uno de los más atinados y ajustados.

Desprovisto de la carga de la consideración del preámbulo, el Tribunal Constitucional acierta aquí - manteniendo la coherencia con sus previos pronunciamientos en esta delicada materia - a asegurar con criterio ponderado y ajustado el respeto a la oficialidad del castellano y la cooficialidad del catalán sobre la base del criterio delimitador de la una y la otra: la territorialidad; lo que vale decir el equilibrio entre ambas.

La idea de equilibrio le permite, en efecto, establecer las alternativas interpretativas posibles en la cuestión de la calificación como «propia» de la lengua catalana y optar para el artículo 6 del Estatuto- por la correcta a la vista de los artículos 3.2 (que refiere la oficialidad de las demás lenguas españolas a las de las respectivas Comunidades Autónomas) y 143.1 CE (condicionamiento del acceso al autogobierno territorial a la concurrencia de una determinada entidad histórica). Pues estas previsiones constitucionales le facilita sintonizar con naturalidad la estatutaria en el orden constitucional: el carácter propio de una lengua es condición para la atribución a ella de cooficialidad, guardando su ulterior cualificación como normal relación tan solo con la realidad social. Pero también aquilatar ponderadamente y cerner con medida adecuada las consecuencias que de tal previsión se hacen seguir, declarando:

a. La inconstitucionalidad, por quebrantadora del antes aludido equilibrio, de la declaración de la lengua catalana —en tanto que cooficial— como de uso preferente como medio de comunicación en el espacio de lo público, sin perjuicio de la legitimidad de una política lingüística proporcionada, favorecedora de aquélla (en la medida necesaria) en tanto que lengua vehicular y de aprendizaje en la enseñanza (junto con el castellano).

b. La constitucionalidad, en virtud de convincente interpretación conforme, de la imposición del deber de conocimiento del catalán sólo en tanto que deber individualizado (en concretas personas) y exigible (de éstas), la sede de cuyo cumplimiento se sitúa, de nuevo, en el ámbito de la educación, pero también — como correlato del derecho de los 
ciudadanos en Cataluña a dirigirse a los poderes públicos en catalán- en el de las relaciones de sujeción especial, es decir, en el organizativo de los medios personales de aquéllos.

Se salva así la presunción constitucional iuris et de iure del conocimiento por todos los ciudadanos únicamente del castellano, que se expresa en el deber de aquéllos de conocerlo; deber, que la norma fundamental no les impone directamente, sin embargo, respecto de las demás lenguas cooficiales. Lo que es plausible afirmar la correspondencia de tal deber con la facultad del poder público de utilización del castellano como medio de comunicación normal con los ciudadanos. Con ello no se niega, aunque no esté prevista expresamente en la Constitución, la facultad del poder público autonómico de comunicarse con ellos en la correspondiente lengua cooficial. Se niega únicamente que idéntica conclusión pueda seguirse del silencio de la norma fundamental sobre el deber de conocimiento de esta última, cuando menos de un deber idéntico del que sí contempla para el castellano. La razón es plenamente convincente: el deber constitucional de conocimiento del castellano es general por tratarse del reverso exacto de la facultad expresamente atribuida a los poderes públicos de utilizar dicha lengua como medio de comunicación sin que los ciudadanos puedan exigirles el empleo de otra (fuera de casos excepcionales, como el de defensa en juicio, irrelevantes para la argumentación de que ahora se trata, por razones evidentes) $)^{31}$.

4 Respecto de la doctrina y los pronunciamientos en el fallo, que contiene la Sentencia sobre la actuación de órganos institucionales del Estado en Cataluña o de nuevos órganos de la Comunidad de Cataluña, como el denominado "Consejo de Justicia de Cataluña», o sobre la participación de la Generalitat en órganos e instituciones estatales ¿qué reflexiones quiere hacernos?

\section{ROBERTO BLANCO VALDÉS}

Como la pregunta incluye muchos temas y todos de gran trascendencia, me referiré tan solo a la cuestión relativa al Consejo de Justicia de Cataluña y a la participación de la Generalitat en órgano o instituciones estatales. Por lo que se refiere al Consejo, no tengo duda alguna (y así lo sostuve en su día en el «Dictamen solicitado por el Defensor del Pueblo sobre el texto del Estatuto de Autonomía de Cataluña») de que la creación de tal institución supone una evidente vulneración de artículo 122.2 de la Constitución, tal y como lo ha reconocido con toda claridad el TC en su Sentencia 31/2010 cuando proclama que «es notorio que el Estatuto catalán incurre en un evidente exceso al crear en el artículo 97 un Consejo de Justicia de Cataluña al que se califica como «órgano de gobierno del poder judicial en Cataluña» y cuyos actos lo serían de un «órgano desconcentrado del poder judicial», siendo así que el poder judicial $[\ldots .$.$] no puede tener más ór-$

31 Facultad ésta, que no se extiende a las lenguas cooficiales con el castellano, pues - teniendo los ciudadanos derecho a utilizar las lenguas cooficiales en sus relaciones con el poder publico, no tienen, sin embargo, obligación de conocer más que el castellano (es decir, solo respecto de éste se presume constitucionalmente el conocimiento). 
gano de gobierno que el Consejo General del Poder Judicial, cuyo Estatuto y funciones quedan expresamente reservados al legislador orgánico». Más discutible me parece, sin embargo, la teoría, que cabe deducir de los fundamentos jurídicos de la Sentencia del TC, de que en realidad el Consejo sólo sería inconstitucional en tanto que se considerase órgano de gobierno del poder judicial, pero que podría no serlo con otra consideración, distinción esa que parece es la que ha llevado al Tribunal a adoptar la decisión, por lo demás pintoresca, de mantener la constitucionalidad de algunas competencias de un órgano inexistente: es decir de uno que, por ser declarado inconstitucional, desaparece, al anularse el artículo que procede a crearlo. De todos modos, y según he tenido ya ocasión de apun$\operatorname{tar}($ «El Estatuto de Cataluña y la sentencia de nunca acabar», en Claves de Razón Práctica, $\left.n^{\circ} 205,2010\right)$ los problemas que deja abiertos tal solución son de notoria importancia, toda vez que la admisión por el TC de la posibilidad de desconcentrar (eso sí, a través de la Ley Orgánica del Poder Judicial) las funciones del Consejo plantea la importantísima cuestión de cuales serían, llegado el caso, los límites de esa posible desconcentración, es decir, cuales son aquellos a partir de los cuales el legislador orgánico no estatutario desnaturalizaría el Consejo General del Poder Judicial como órgano de gobierno del mismo (art. 122.2 de la Constitución) y violaría lo en ella taxativamente establecido cuando lo creó.

Las diversas consideraciones contenidas en la Sentencia 31/2010 en relación con la participación de la Generalitat en órgano o instituciones estatales me parecen difícilmente discutibles: según ellas, las previsiones estatutarias al respecto no pueden, de ningún modo «impedir o menoscabar el libre y pleno ejercicio de las competencias estatales», de lo que se deduce, al cabo, que tales previsiones quedan vacías de contenido, al carecer de auténtica eficacia jurídica. Siendo ello así, que a mi juicio lo es, lo lógico hubiera resultado, en todo caso, que se hubiera procedido a anular preceptos que sencillamente regulan cuestiones que un Estatuto no puede regular por carecer de competencia material para ello. El TC, guiado sin duda por su parti pris de reducir al mínimo las declaraciones de inconstitucionalidad, aún en aquellos casos en que la misma resulta manifiesta, cae en este caso en otra falta de coherencia pues su Sentencia establece el criterio interpretativo antes citado en relación con los artículos 174.3 (que fija el principio general de que la Generalitat participa en las instituciones, organismos y procedimientos de toma de decisiones del Estado que afecten a sus competencias) y 180 (que prevé la misma participación en los procesos de designación de magistrados del TC y miembros del Consejo General del Poder Judicial), pero no en relación con el 181 (relativo a la participación de la Generalitat en la ordenación general de la actividad económica) o con el 182 (relativo a la designación de representantes, por parte de la Generalitat, en determinados organismos económicos y sociales, como el Banco de España, la Comisión Nacional del Mercado de Valores o la Comisión del Mercado de las Telecomunicaciones). Y es que, o por evidente, sobra aclarar, como se hace en relación con el 180 que «la participación de la Generalitat se condiciona, en su existencia y procedimientos, a lo que dispongan, dentro del margen que la Constitución les permite, las leyes orgánicas correspondientes»; o, por no serlo, resulta necesario determinarlo así en todos los casos. 


\section{RAÚl CANOSA USERA}

La autonomía institucional para configurar los órganos autonómicos que la Constitución (artículos 147.2 y 152.1) reconoce al poder estatuyente encuentra ciertos límites en la propia Constitución que, según la STC 31/2010, se habían rebasado; así la exclusividad del Sindic de Greugues para proteger en el ámbito catalán todos los derechos, también los constitucionales, con exclusión del Defensor del Pueblo estatal. Asimismo se declara la inconstitucionalidad de los efectos vinculantes de los dictámenes del Consejo de Garantías Estatutarias cuando informa acerca de proyectos o proposiciones de ley que afectasen a los derechos estatutarios, al entender que si el informe es negativo y se paraliza el procedimiento legislativo, el afectado es el Parlamento y por ende el principio democrático, mientras que si el informe es positivo, se efectúa un control que quiebra el monopolio del enjuiciamiento de normas con valor de ley que ostenta el Tribunal Constitucional.

Tampoco queda indemne el Consejo de Justicia de Cataluña con la anulación del artículo 97 y del casi todo el artículo 98 que lo creaba y anticipaba sus funciones, aunque se remitía a la LOPJ, por mucho que algunos propugnen ahora su creación en esta Ley Orgánica. El Tribunal no ha respaldado el intento de privar a un órgano constitucional como el CGPJ de algunas de sus funciones constitucionales, por más que el órgano beneficiario se presentase como resultado de una desconcentración. En consecuencia invalida las referencias al Consejo Judicial de Cataluña que contenían los apartados 5 y 6 del artículo 98 (participación del Consejo en los nombramientos de los presidentes del Tribunal superior y de sus Salas). En este punto se descarta la técnica de condicionar los contenidos de futuras leyes orgánicas que bendijo la STC 247/2007 porque afectaban al núcleo de las funciones atribuidas a un órgano constitucional.

Se reafirma, en suma, la peculiar separación vertical de poderes española que alcanza a los poderes legislativo y ejecutivo, pero no al judicial, de tal suerte que el embrión del poder judicial catalán que la creación del Consejo de Justicia de Cataluña auspiciaba, ha sido desactivado, de tal modo que tal pretensión sólo será posible mediante la reforma constitucional.

\section{FranCESC DE CARRERAS SERra}

Sólo me referiré al segundo punto, es decir, a la participación de la Generalitat en órganos e instituciones estatales, aspecto estrechamente ligado al contenido de un estatuto de autonomía, materia sobre la cual formularé algunas consideraciones.

Precisamente la sentencia dedica parte de los FJ 4 a 6 a precisar el contenido de los estatutos. Delimitar este contenido en los primeros fundamentos resulta sumamente acertado ya que sirve para orientar toda la sentencia. Una posición restrictiva en este punto, el contenido de los estatutos, hubiera tenido como consecuencia la declaración de nulidad de buena parte del Estatuto por desbordar éste, claramente, las materias que le están estrictamente reservadas en la Constitución. En total, algo más de un centenar de artículos hubieran quedado afectados de inconstitucionalidad por no ser objeto de materia estatutaria. El Tribunal, pues, ha realizado un gran esfuerzo para ser deferente con el legis- 
lador al justificar una concepción amplia del contenido estatutario que le ha permitido salvar la literalidad de buena parte del texto legal aún cuando después, al descender a examinarlo en detalle, haya desvirtuado el sentido de muchas de estas normas por vía interpretativa. Así, a pesar de la generosidad — a mi modo de ver excesiva, como después veremos - en la ampliación material de los estatutos, a la postre muchos de los efectos jurídicos del texto estatutario quedan muy limitados o casi nulos.

Con la finalidad de delimitar el contenido estatutario, la sentencia distingue entre un contenido constitucionalmente explícito y otro implícito, tal como ya expuso el Tribunal en la sentencia 247/2007, sobre el Estatuto de la Comunidad Valenciana. El contenido explícito es el mencionado en el art. 147.2 CE y en los preceptos constitucionales relativos a la lengua (art. 3 CE), los símbolos (art. 4 CE) o la composición del Senado (art. 69.5 CE), entre otros. Es decir, se trata del contenido expresamente fijado en la Constitución. El contenido implícito, es decir, el no fijado expresamente en la Constitución, es el complemento adecuado del anterior por su conexión con las citadas previsiones constitucionales, fundamentándose tal adecuación en la función que la norma suprema encomienda a los Estatutos debido a su condición de normas institucionales básicas de las comunidades autónomas (art. 147.1 CE).

Esta expansión del contenido estatutario tiene, de acuerdo con la sentencia y como es obvio, algunos límites evidentes. Por ejemplo, las reservas constitucionales a favor de leyes específicas, como es el caso de las leyes orgánicas del Poder Judicial y del Tribunal Constitucional u otras leyes orgánicas en materias no autonómicas. Otros límites, sin embargo, ni son tan evidentes ni están perfilados con claridad en la misma sentencia, ya que se plantean en un plano de gran abstracción y la misma sentencia reconoce que su delimitación concreta sólo puede llevarse a cabo desde el mismo Tribunal Constitucional, teniendo en cuenta, por un lado, la divisoria entre la Constitución y los poderes constituidos y, por otro, la eficacia regular del sistema en su conjunto.

Desde ambos puntos de vista, distingue, a su vez, entre límites cualitativos y cuantitativos. Los primeros deben tener en cuenta que los estatutos son normas rígidas que inevitablemente implican una cierta petrificación del ordenamiento, debiendo hacerse ello compatible con el derecho de participación política para no impedir que el principio de irreversibilidad de las normas, inherente a la misma idea de democracia. Dicha delimitación está, pues, planteada en términos generales que deberán ser concretados de forma casuística. Por tanto, hay que considerar excepcionales las leyes que -como el Estatuto- han sido aprobadas mediante procedimientos agravados y por mayorías cualificadas. Asimismo, considera el Tribunal que una regulación de detalle en los estatutos sólo puede objetarse por razones de oportunidad, aunque sin olvidar, como se dijo en la STC 247/2007, que lo propio de los estatutos es regular aspectos «centrales o nucleares» de las instituciones y las competencias, con lo cual implícitamente excluye, contradiciendo lo dicho anteriormente, regular en un estatuto aspectos de detalle. Otros límites señalados por la sentencia son los cualitativos, es decir, aquellos contenidos que no se corresponden con materias estatutarias porque, de acuerdo con su naturaleza, son propios de una norma nacida del poder constituyente, es decir, de una Constitución, no de una norma procedente de los poderes constituidos como es el caso de los estatutos.

Pues bien, comprendiendo el esfuerzo del Tribunal para ampliar en los posible el campo de materias a regular en los estatutos, aunque no estando de acuerdo con la 
magnitud de tal ampliación, si aplicamos estos presupuestos lo que no cabe en un estatuto son artículos como el 180 EAC en el que se establece que la «Generalitat participa en los procesos de designación de magistrados del Tribunal Constitucional y de miembros del Consejo General del Poder Judicial», o el art. 182 EAC en el que se dice que la Generalitat «designa o participa» en los procesos de designación de miembros de organismos económicos y sociales tales como el Banco de España, la Comisión Nacional del Mercado de Valores, de las Comunicaciones, el Tribunal de Cuentas, el Consejo Económico y Social, etc. Igual sucede con el art. 183 EAC que regula las funciones y composición de la Comisión Bilateral Estado-Generalitat. Estos artículos no deberían haber sido objeto de una hábil interpretación conforme sino de una declaración de nulidad en todas regla por la razón formal de exceder el contenido de un estatuto de acuerdo con la doctrina que el propio Tribunal construye en la misma sentencia, independientemente de que después, en un buen entendimiento de lo que es el federalismo cooperativo, tal participación se llevara a efecto en algunos casos. Igual sucede, obviamente, en otros preceptos del título dedicado a la Justicia que no han sido objeto de nulidad.

No basta, pues, con sostener, acertadamente, que el Estado tiene plena libertad para el ejercicio de sus propias competencias sin estar condicionado para nada por un estatuto. Es de puro sentido común, además de rigor técnico-jurídico, que un estatuto, por su carácter territorial, no es la norma adecuada para vincular a instituciones estatales. También es cierto que en virtud de los principios de colaboración y participación, de carácter netamente federal, las comunidades autónomas - todas ellas, no sólo Cataluña — pueden participar, directa o indirectamente, en la designación de miembros de determinadas instituciones estatales que afectan a competencias autonómicas, como son los órganos antes enunciados y los demás del art. 182 EAC. Pero ello sólo puede ser dispuesto en las leyes estatales correspondientes, no en un estatuto que, si bien es una ley estatal, no admite en su ámbito de regulación estas materias, incluso en una interpretación tan amplia como la establecida por el Tribunal en la propia sentencia.

En conclusión, cabe hacerse una pregunta: ¿qué significado puede atribuirse a tales preceptos si, a pesar de ser válidos, dado que se ha salvado la literalidad del texto, no permiten tal participación de la Generalitat sin que lo prevea una ley estatal en la cual el legislador — también estatal, por supuesto - tiene plena libertad para el ejercicio de su competencia sin condicionante alguno? ¿Se trata de auténticas normas jurídicas — por tanto vinculantes - o son un mero desideratum de intenciones programáticas basadas en criterios de conveniencia y oportunidad? Tal como han quedado estos preceptos tras la interpretación llevada a cabo en la sentencia, más bien se asemejan a lo último. Razón de más para declararlos nulos.

\section{Marc Carrillo LóPez}

La previsión estatutaria de configurar el Consejo de Justicia de Cataluña (CJC) Cap. II- como un órgano desconcentrado del Consejo General del Poder Judicial (CGPJ) (art. $97 \mathrm{EAC}$ ), lo era siempre de acuerdo con lo que en su caso estableciese la 
LOPJ a la que el Estatuto hacía constante remisión. En este Cap. II del Título III, sobre el Poder Judicial en Cataluña (no de Cataluña) el Estatuto establecía una serie de preceptos de baja densidad normativa puesto que su efectividad dependía siempre de lo que el legislador estatal estableciese al respecto. No hay que olvidar que un proyecto de reforma de la LOPJ simultáneo al trámite legislativo a la aprobación del Estatuto, ya se pretendía la introducción de los consejos territoriales para todas las CCAA, que finalmente no llegó prosperar.

El TC rechaza la creación de este órgano por el Estatuto pero no niega que ello lo pueda hacer el Estado a través de la LOPJ. Sus argumentos parten de unas premisas cuestionables. La primera no se compadece bien con la realidad del Derecho Comparado judicial, ya que afirma que «una de las características definidoras del estado autonómico, por contraste con el federal, es que su diversidad funcional y orgánica no alcanza en ningún caso a la jurisdicción» (FJ 42), lo cual no siempre es así. No en todos los estados federales los territorios que integran el Estado disponen de jurisdicción propia, como es el caso, por ejemplo de Austria donde su poder judicial es único y los Länders carecen de tribunales propios, o de Bélgica donde ocurre lo propio. En todo caso ésta no era la cuestión que se planteaba en el Estatuto pues, como no podía ser de otra manera, el Consejo de Justicia no era un órgano jurisdiccional.

La segunda se construye bajo el argumento de que «si el Estado autonómico arranca con una Constitución única, concluye con una jurisdicción también única...» y que «la unidad de la jurisdicción y del Poder Judicial es así, en el ámbito de la concreción normativa, el equivalente de la unidad de la voluntad constituyente...» (FJ 42). Y añade que «la estructura territorial del Estado es indiferente, por principio, para el judicial como Poder del Estado» (FJ 42). Por tanto, para el Tribunal la unidad de jurisdicción es una consecuencia de la unidad del poder constituyente. Pero con esta posición tan extrema se sitúa extramuros de su propia jurisprudencia sobre las competencias en materia de justicia y la relación de colaboración normativa entre la LOPJ y los Estatutos de de autonomía que establecía en la STC 56/1990 (FJ 35): «(...) el precepto orgánico ( el relativo a la LOPJ) viene de hecho a interpretar extensivamente las disposiciones estatutarias, al excluir de la casación ante el Tribunal Supremo las Sentencias de los Tribunales Superiores de Justicia en relación a actos y disposiciones de las Comunidades...». Esta interpretación de 1990, relativa a los recursos planteados entonces contra la LOPJ 6/1985, sometida a la luz de la 31/2010 podría resultar incluso atentatoria a la unidad del Poder Judicial.

Claro es que acto seguido reconoce que la unidad orgánica y funcional del Poder Judicial si bien queda «asegurada en su sustancia con la atribución al Estado de la competencia exclusiva en materia de Administración de Justicia, es perfectamente compatible con el reconocimiento a las Comunidades Autónomas de determinadas competencias en el ámbito de la administración de la Administración de justicia», cuando así resulta de su titularidad sobre competencias propias de la vertiente puramente administrativa al servicio de la función jurisdiccional del Estado». Con lo cual, si se reconoce al Consejo de Justicia la condición de órgano administrativo desconcentrado del CGPG y en ningún caso, de órgano jurisdiccional, la puerta para su existencia no había de quedar cerrada. Aunque una parte de sus funciones se proyectasen sobre el personal jurisdiccional del Poder Judicial, siempre y cuando la LOPJ, a la que constantemente se remitía el Estatuto, así lo estableciese. Es decir, a partir del principio de colaboración internormativa entre el 
Estatuto y la LOPJ ${ }^{32}$ que ya aceptaba la citada STC 56/1990, el Consejo de Justicia podía disponer de cobertura constitucional.

Sin embargo, la STC 31/2010, en la lógica que preside su contenido, de degradar el Estatuto como norma, considera que «es notorio que el Estatuto catalán incurre en un evidente exceso al crear en el art. 97 un Consejo de Justicia...» (FJ 47): sus argumentos son que «ningún órgano, salvo el CGPJ, puede ejercer la función de Gobierno de los órganos jurisdiccionales integrados en el Poder Judicial exclusivo del Estado, ni otra ley que no sea la Orgánica del Poder Judicial puede determinar la estructura y funciones de aquel Consejo» (FJ 47). No obstante, el Tribunal no rechaza la posibilidad de que sea la LOPJ — pero nunca el Estatuto- la que en su caso pueda prever una fórmula de desconcentración de funciones que corresponde al CGPJ, que pudiese resultar similar al Consejo de Justicia. Pero desiste de dar cabida a una solución constitucional a la forma de desconcentración administrativa tomada por el Estatuto en el gobierno del Poder Judicial, consistente en aceptar la interrelación entre el Estatuto y la LOPJ para que fuese esta última la que determinase la efectividad plena del Consejo. El rechazo que la sentencia establece a esta posibilidad la conduce a declarar la inconstitucionalidad de la existencia del Consejo de Justicia (art. 97 EAC). Pero curiosa e incoherentemente, la sentencia extiende la inconstitucionalidad a parte de las atribuciones del Consejo pero reconoce la constitucionalidad de las restantes. El argumento es que en el primer caso se trata de aquellas que se proyectan sobre la función jurisdiccional y la independencia de su ejercicio, mientras que las otras se acomodan a la Constitución pues se relacionan con las competencias de las CCAA relativas a la llamada administración de la Administración de Justicia. No parece que sea muy lógico expulsar del ordenamiento un órgano y al mismo tiempo, mantener una parte de las atribuciones que le han sido asignadas a un titular que ha dejado de existir. Ciertamente, todo ello podría verse reparado por una eventual reforma de la LOPJ. Aunque quizás y ésta es cuestión distinta - no sería del todo ocioso plantearse la oportunidad de la desconcentración del órgano de gobierno del Poder Judicial habida cuenta de la cuestionable experiencia institucional que hasta ahora ha ofrecido el CGPJ.

En cuanto a otro de los nuevos órganos surgidos del Estatuto, merece especial mención el caso del Consejo de Garantías Estatutarias (art 76 EAC). La sentencia ha interpretado que la competencia atribuida a este órgano consultivo y de control de la estatutoriedad, para emitir un dictamen vinculante sobre los proyectos o proposiciones de ley que desplieguen o afecten a los derechos reconocidos por el Estatuto (art. 76.4 EAC) es contraria a la Constitución. Sus argumentos han sido dos: 1) si el control del Consejo se llevara a cabo en el momento de la presentación de las iniciativas legislativas delante de la Cámara o a lo largo de su debate delante de la misma, «supondría una inadmisible limitación de la autoridad y las competencias parlamentarias, con grave quebranto de los derechos de participación política reconocidos por el art. 23 CE en garantía de la libertad parlamentaría propia de los sistemas democráticos»; 2) si el control se verificara una vez concluido el procedimiento legislativo, pero antes de la publicación de la ley, eso «configuraría el control ejercido por el Consejo en términos demasiado próximos (materialmente equivalentes, desde luego) a un

32 Vid. Cabellos Espiérrez, M. A., «Poder Judicial y modelo de Estado en la sentencia sobre el Estauto de Autonomía de Cataluña», Revista Catalana de Dret Públic (Especial Sentència sobre l'Estatut). Edición Electrónica, 2010 (http://www,rcdp.cat). 
control jurisdiccional sobre normas legales enteramente perfeccionadas en su contenido, perjudicándose entonces el monopolio de rechazo con fuerza de ley reservado por el art. 161 CE a este Tribunal» (FJ 32). Son argumentos muy discutibles y hay razones para cuestionarlos ${ }^{33}$.

Antes que nada, conviene precisar que con el dictamen vinculante la naturaleza jurídica del Consejo dejaba de ser la que corresponde a un órgano consultivo, para adoptar una nueva en forma de auto-control institucional de carácter preventivo sobre un proyecto o proposición de ley, de acuerdo con la opinio iuris emitida por un colegio de juristas. Pero sin que ni mucho menos operase como un control jurisdiccional: porque el Consejo su función de control no se ejerce sobre normas vigentes sino sobre iniciativas legislativas. El sentido del dictamen vinculante en materia de derechos era el de ser una garantía específica ante eventuales excesos del legislador autonómico, que en el seno del iter legislativo podían ser corregidos antes de que el proyecto o proposición se convirtiesen en ley. No se olvide que ante la imposibilidad legal de que las minorías parlamentarias autonómicas puedan recurrir una ley de su propio Parlamento, el dictamen del Consejo era una garantía previa para controlar la adecuación de la iniciativa legislativa a los derechos reconocidos en el Estatuto.

Sobre el primer argumento invocado por STC 31/2010, según el cual el dictamen vinculante suponía una inadmisible limitación de las competencias parlamentarias y de los derechos de participación política, cabe argüir que difícilmente se puede concluir como lo ha hecho la sentencia. Principalmente, porque era el mismo Estatuto la norma que imponía un autocontrol interno realizado por el Consejo a instancia de parte, en la que procesalmente podían participar los propios parlamentarios. En efecto, son los diputados -en el ejercicio conjunto del ius in officium (art. $23 \mathrm{CE}$ ) - los que disponen de legitimación activa en un número mínimo de ellos (una décima parte de los diputados o dos grupos parlamentarios) para solicitar el dictamen al Consejo, con el fin de verificar si el texto legislativo es o no respetuoso con el Estatuto (art. 23. b, de la Ley 2/2009, del 12 de febrero, del Consejo de Garantías Estatutarias). Si los diputados pueden instar la actuación del Consejo sobre una iniciativa de la que dudan sobre su adecuación al Estatuto, no resulta fácil deducir que eso pueda suponer «un grave quebranto de los derechos de participación política reconocidos por el art. 23 CE».

El TC señala que la indeterminación del modelo de control ejercido por el Consejo hacía posible una pluralidad de opciones que pasaban por dos extremos: uno primero, ejercer el control en el momento de que se presente la iniciativa legislativa y a lo largo del debate sobre la misma; y el segundo, una vez acabado el procedimiento legislativo. Pues bien, no tiene demasiado sentido y es poco verosímil que el control se hiciera al ini$\mathrm{cio}^{34}$ situación que de darse, sí que hubiera supuesto una limitación de los derechos de participación política de los diputados. Pero la experiencia práctica de la función consultiva ejercida por el antiguo Consejo Consultivo a lo largo de casi veinte años permitía

33 La intervención del Consejo de Garantías Estatutarias en el íter legislativo de un proyecto o proposición de ley se produce en su última fase: es decir, los dictámenes del Consejo son emitidos después de la aprobación del dictamen por la Comisión parlamentaria que corresponda, sobre el proyecto o proposición de ley y, por lo tanto, antes del debate final en el pleno del Parlamento (art. 111 del Reglamento del Parlamento de Cataluña).

34 Tornos MÁs, J.: «El Consell de Garanties Estatutàries». Revista Catalana de Dret Públic. Número especial, Setiembre 2010. (versión electrónica); VinTró CAStells, J. «Els dictàmens vinculants del Consell de Garanties Estatutàries», Revista Catalana de Dret Públic. Número especial, Setiembre 2010 (versión electrónica). 
excluir esta opción y, por contra, retener como criterio interpretativo el que ha sido aplicado por la Ley 1/ 1981, del 25 de febrero, del Consejo Consultivo de la Generalitat y ahora para la Ley 2/2009, del 12 de febrero, del Consejo de Garantías Estatutarias. Es decir, el dictamen del Consejo únicamente se puede solicitar una vez la comisión parlamentaria correspondiente haya aprobado su propio dictamen respecto del proyecto o proposición de ley objeto de debate. Es decir, en un momento del íter legislativo en el que -salvo la deliberación en el pleno- ya se han ejercido buena parte de las facultades de propuesta y de libre debate de los diputados sobre el texto legislativo y, si procede, también sobre la solicitud de dictamen formulada al Consejo de Garantías. Con este primer argumento de inconstitucionalidad, el TC ha optado por una decisión extrema, cuando por las razones expuestas la previsión estatutaria del dictamen vinculante, era susceptible de admitir una interpretación conforme a la Constitución.

El segundo argumento sostenido a la sentencia se fundamenta en que si el control ejercido por el Consejo se produjera una vez acabado el procedimiento legislativo y antes de la publicación de la ley, comportaría una forma de control demasiado próxima (en todo caso, materialmente equivalente) a un control jurisdiccional, causando un perjuicio al monopolio de rechazo de las normas con fuerza de ley que está reservado en el TC (art. $161 \mathrm{CE})$. Pero este argumento olvida que el control ejercido por el Consejo es un autocontrol previo en el seno del procedimiento legislativo, que no se proyecta sobre una disposición válida sino sobre un proyecto o proposición de ley. Cuándo es evidente que el monopolio del control de constitucionalidad del TC se ejerce sobre las normas válidas, no sobre proyectos o proposiciones.

De la argumentación utilizada por la sentencia, parece claramente derivarse que con el dictamen vinculado el Consejo hubiera suplantado la función jurisdiccional del TC. Sin embargo, y además de lo que se acaba de exponer, hay que añadir a contrario dos argumentos adicionales. Primero, en el supuesto que de una ley autonómica, previamente dictaminada por el Consejo desarrollara o afectara a derechos estatutarios, y hubiera sido impugnada ante Tribunal Constitucional, esta ley aprobada por el Parlamento de Cataluña siempre sería el resultado del ejercicio de la potestad legislativa de la cual es únicamente titular el Parlamento y, a su vez, del derecho de participación política que pertenece a los diputados. Y no de una hipotética concurrencia de decisiones entre el Consejo de Garantías Estatutarias y el Parlamento. Segundo, si dado el caso de un dictamen negativo y, de acuerdo con lo mismo, el proyecto legislativo hubiera sido aprobado conforme al dictamen, y posteriormente la ley hubiera sido impugnada ante el Tribunal Constitucional, el control previo estatutario a que fue sometida ante el Consejo de Garantías Estatutarias, en ningún caso vincularía el juicio del Tribunal. El Consejo no habría suplantado las funciones jurisdiccionales del Tribunal Constitucional, ya que su control de constitucionalidad se habría ejercido sobre una norma resultante del ejercicio de la potestad legislativa del Parlamento de Cataluña ${ }^{35}$, sin ningún condicionamiento previo derivado de la opinio iuris emitida por el órgano estatutario. También en este caso, el juicio del TC admitía, a mi parecer, una técnica interpretativa más deferente con el legislador autonómico.

35 Carrillo, M.: «Después de la sentencia, un Estatuto desactivado», El Cronista del Estado Social y Democrático de Derecho. (Especial sobre la STC 31/2010), Octubre, 2010 págs. 26-37). 
Finalmente, acerca de la participación de la Generalidad en órganos del Estado, las previsiones estatutarias son un ejemplo más de preceptos de naturaleza programática, carente de fuerza normativa por sí mismo, pues el Estatuto se limita a remitirse a lo que la ley estatal establezca al respecto. Así ocurre, por ejemplo, con la designación de miembros del Tribunal Constitucional (art. 180 EAC). Ante este impulso soft que parte del Estatuto, el legislador estatal respondió posteriormente con la Ley Orgánica 6/2007, de 24 de mayo, de reforma de la Ley Orgánica 2/1979, de 3 de octubre del Tribunal Constitucional, que regula la participación de las CCAA, a través del Senado, con el nombramiento de magistrados del TC. Una participación sobre la que cabe recordar que, sin embargo, tras la interpretación dada por la STC 101/2008, de 24 de julio, sobre el art. 184.7 del Reglamento del Senado, que regula el procedimiento para la propuesta de magistrados por parte de los Parlamentos de las CCAA, ha avalado la interpretación con fraude de ley que ha consistido en que diversas CCAA presenten un mismo candidato.

\section{JAVIER CORCUera ATIENZA}

Me hubiera extrañado que la sentencia hubiera podido decir otra cosa. Ya desde el primer proceso autonómico pareció quedar claro que el Estatuto, pese a ser una ley orgánica, no podía cumplir las funciones que la Constitución encomienda a otras leyes orgánicas. Ello afecta, por supuesto, a la Orgánica del Poder Judicial. Y tampoco podía haber sido otra la postura a la hora de definir vías de participación de la Generalidad en órganos institucionales del Estado, o a la puesta en marcha de instrumentos de colaboración bilaterales en materias de competencia del Estado: puede legítimamente el Estatuto definir lugares de encuentro, o instrumentos de cooperación y colaboración en asuntos que afecten a competencia o intereses de la Comunidad, pero si se trata de materias de competencia exclusiva del Estado, es al legislador estatal a quien corresponde determinar libremente tal participación, que no podrá tener lugar en órganos de carácter decisorio, «debiendo en todo caso dejar a salvo las referidas participaciones orgánica y funcional la titularidad de las competencias estatales eventualmente implicadas y la perfecta libertad que en su ejercicio corresponde a los organismos e instituciones del Estado» (FJ 65).

\section{JAVIER GARCÍA RoCA}

Me limitaré a dos cuestiones el restringido papel del Estatuto frente a la reserva constitucional a la LOPJ, y el carácter no vinculante de los dictámenes del Consejo de Garantías Estatutarias, heredero del Consejo Consultivo.

1.- Me parece bien en general lo que se dice sobre el Poder Judicial y creo que podríamos incrementar en la LOPJ las competencias de los TSJ, tanto como que no deberíamos iniciar allí el innecesario experimento de unos capitidisminuidos Consejos de Justicia.

El Tribunal afirma que «una de las características definidoras del Estado autonómico, por contraste con el federal, es que su diversidad funcional y orgánica no al- 
canza en ningún caso a la jurisdicción»; y que «la estructura territorial del Estado es indiferente, por principio, para el Judicial como Poder del Estado» (STC 31/2010, F.J. 42 y ss). Efectivamente, nuestro modelo constitucional no contempla un Poder Judicial en cada Comunidad Autónoma, si bien la frase entrecomillada es algo excesiva y engañosa a la vista de la jurisprudencia recaída sobre la descentralización de la administración al servicio de la Administración de justicia y de los sucesivos desarrollos estatutarios y las llamadas cláusulas subrogatorias.

Con relación al Tribunal Superior de Justicia de Cataluña y sus competencias se señala que lo son «en los términos establecidos por la ley orgánica correspondiente», y que ésta solo puede ser la LOPJ, a lo que no se opone el artículo 95.1 ni el 95.2, ni el 95.4 del Estatuto. Si bien se hace preciso una sentencia interpretativa del inciso «la competencia reservada al Tribunal Supremo para la unificación de doctrina» del artículo 95.2 EAC (F.J. $44^{\circ}$ ), ya que es evidente que es sólo la LOPJ la que puede contraer la competencia de ese Tribunal al conocimiento de un determinado recurso, y definir las competencias del Tribunal Supremo.

El Tribunal muestra las limitaciones del Estatuto para abordar una materia, aún por invitación, que está constitucionalmente reservada a la LOPJ. Sólo esta Ley puede fijar las competencias del Tribunal Supremo y del Tribunal Superior de Justicia. La solución de cualquier controversia futura queda reenviada a una hipotética modificación de la misma. Pero, a mi entender, incrementar las competencias de revisión de los TSJ y centrar al Tribunal Supremo en sus funciones de casación puede ser sensato y coherente con la intensa descentralización administrativa que poseemos.

Es, sobre todo, cabal la decisión de que no es constitucional un Consejo de Justicia de Cataluña concebido como órgano de desconcentración del Consejo General del Poder Judicial y de gobierno de los jueces. Pero sí podría ser —admite el Tribunal— un órgano relacionado con las competencias autonómicas sobre la administración al servicio de la administración de justicia, v.gr., la potestad reglamentaria y ejecutiva sobre el personal no judicial al servicio de la Administración de Justicia y sobre el diseño de las oficinas de justicia, la realización de propuestas sobre la demarcación, planta y capitalidad judiciales, etc.

La sentencia afirma que el artículo 97 EAC incurría en un evidente exceso» al crear un Consejo de Justicia de Cataluña al que se califica de órgano de gobierno del Poder Judicial en Cataluña (F.J. $47^{\circ}$ ). Es obvia la infracción de los arts. 122.2 CE y 149.1.5 CE, pues, según es doctrina reiterada, ningún órgano, salvo el Consejo General del Poder Judicial, puede ejercer la función de gobierno de los órganos jurisdiccionales integrados en el Poder Judicial, ni otra que no sea la LOPJ puede determinar la estructura y funciones de aquel Consejo. Ahora bien, la impropiedad constitucional de un órgano autonómico cualificado en los términos del art. 97 EAC no significa fatalmente la inconstitucionalidad misma del órgano en cuestión. Sólo si todas y cada una de sus concretas atribuciones se correspondieran, además, con esa cualificación impropia, sería inevitable la inconstitucionalidad y nulidad del órgano. El art. 97 EAC es inconstitucional en la medida en que califica al Consejo de Justicia de Cataluña como «órgano de gobierno del Poder Judicial» que actúa como órgano desconcentrado del Consejo General del Poder Judicial. La pervivencia del Consejo de Justicia de Cataluña, una vez excluida su in- 
constitucional conceptuación, dependerá del juicio que merezcan las atribuciones que se le confieren en el art. 98 EAC.

En todo caso, la inconstitucionalidad de principio advertida ha de implicar, por conexión, la de los arts. 98.3 y 100.1 EAC, en cuanto el primero parte de la posibilidad de que el Consejo de Justicia dicte resoluciones en materia de nombramientos, autorizaciones, licencias y permisos de Jueces. Y, en cuanto a su composición, al no ser un órgano de Gobierno del Poder Judicial, no puede estar integrado por Jueces, al no ser el Estatuto una norma que pueda prever una excepción en el sentido del 117.4 CE (F.J. 49º). Respecto de las competencias, y al margen de lo que puedan establecer las futuras leyes, sobre las que no procede pronunciarse en este momento (F.J. $50^{\circ}$ ), se distingue dentro de las que son directamente atribuidas por el Estatuto ente las que son típicas de un órgano de Gobierno del Poder Judicial (por ejemplo, convocatoria de concursos para cubrir plazas vacantes de Magistrados, funciones disciplinarias sobre jueces), que son claramente inconstitucionales, de aquellas otras que se pueden incluir entre las competencias de administración de justicia, asumibles por las CCAA que no plantean ningún reparo constitucional.

Queda pues abierto el debate en una hipotética modificación de la LOPJ sobre si conviene configurar o no unos Consejos de Justicia con competencias restringidas a la administración al servicio de la administración de justicia. A mi entender, es razonable pensar que la pequeña dimensión de estas competencias administrativas no parece justificar la grandilocuencia del rótulo, la misma creación del órgano, ni sus elevados costes ni, especialmente, el riesgo de generar falsas expectativas sobre las funciones del órgano. La experiencia en el funcionamiento del CGPJ no es, por otro lado, tan halagüeña como para que resulte estimulante seguir realizando experimentos organizativos análogos. El debate no creo debiera abrirse por razones de oportunidad política, no de constitucionalidad, una vez realizada la intensa poda de las atribuciones posibles de un hipotético Consejo de Justicia que ha hecho el Tribunal.

2.- En relación al Consejo de Garantías Estatutarias, se declara la inconstitucionalidad del carácter vinculante de sus dictámenes, extremo que me suscita algunas dudas. En todo caso, el problema no es grave y la solución podría venir por la vía de que las Asambleas de las Comunidades Autónomas desarrollen el uso o convención de acatar los dictámenes jurídicos no vinculantes que soliciten a esos Consejos.

Se impugnaron los apartados 1, 2 y 4 del artículo 76 EAC por entender que las funciones que allí se otorgaban a ese Consejo violan la reserva del control de constitucionalidad de las leyes en favor del Tribunal Constitucional (artículo $161 \mathrm{CE}$ ). El Tribunal (STC 31/2010, F.J. $32^{\circ}$ ) considera inocuo el apartado $1^{\circ}$ que define la institución, así como el apartado $2^{\circ}$ que establece sus competencias, que son similares a las que tenía el anterior Consejo Consultivo cuya constitucionalidad ya había sido declarada por la STC 204/1992, de 26 de noviembre. Se centra pues la motivación en el apartado 4 que atribuye carácter vinculante a sus dictámenes «con relación a los proyectos de ley y las proposiciones de ley del Parlamento que desarrollen o afecten a derechos reconocidos por el presente Estatuto». El control podría realizarse bien en el momento de la presentación de las iniciativas legislativas en la Cámara y a lo largo de su debate en la misma (por este momento intermedio opta la ley autonómica que lo regula) o bien una vez concluido el procedimiento legislativo y antes de la publicación de la ley. Mas se concluye que lo 
primero supondría una inadmisible limitación de la autoridad y las competencias parlamentarias, con grave quebranto de los derechos de participación política reconocidos por el art. 23 CE, en garantía de la libertad parlamentaria propia de los sistemas democráticos; y, lo segundo, configuraría el control ejercido por el Consejo en términos demasiado próximos (materialmente equivalentes) a un control jurisdiccional sobre normas legales enteramente perfeccionadas en su contenido, perjudicándose entonces el monopolio de rechazo de las normas con fuerza de ley reservado por el art. $161 \mathrm{CE}$ a este Tribunal. En cualquiera de las dos hipótesis, procede la declaración de inconstitucionalidad.

A mi juicio, la motivación es lacónica y demasiado asertiva y por ello escasamente convincente. Es discutible que un Estatuto, que previamente se ha definido como una ley orgánica, no pueda configurar un derecho fundamental de configuración legal como es precisamente el recogido en el artículo 23.2 CE y atribuir consecuencias, internas al proceso de formación de la voluntad de la Comunidad, previendo la intervención jurídica de un órgano consultivo que se pronuncie sobre las regularidad de las leyes por su adecuación al Estatuto, precisamente en uso de su poder de organización interna. Pero, sobre todo, no advierto daño alguno en la superposición de garantías cuando la subsidiariedad garantiza la supremacía de la instancia final, el Tribunal Constitucional, y podrían haberse señalado perfectamente limitaciones materiales al alcance del control en la primera practicada por el Consejo de Garantías, ambas cosas me parece permitían alejar posibles desconfianzas y recelos. Es habitual así en los Estados federales que el Tribunal Constitucional federal se apoye y colabore, con una división de tareas, con los tribunales constitucionales de los Estados. También se ha esgrimido en el debate que esta previsión estatutaria podría violar lo dispuesto en el artículo 152.1 CE, pero la naturaleza de regulación de mínimos de la organización institucional dispuesta en este precepto, muy sobrepasado en la organización actual de las Comunidades Autónomas, dotadas de otras muchas instituciones, funciones y procedimientos en sus Estatutos e incluso en sus leyes, me parece lleva a no poder sobrevalorar este argumento.

\section{Luciano Parejo Alonso}

La incidencia del Estatuto de Autonomía en la organización del Estado central se ventila en la Sentencia en tres momentos distintos: al tratar de la regulación del poder judicial en Cataluña, al examinar las relaciones institucionales de la Generalitat y al enjuiciar la asunción de competencias. Siendo más oportuno abordar esta última al hilo del comentario de los razonamientos referidos a la asunción de competencias, me concentraré ahora en las dos primeras.

Debo comenzar diciendo que el tratamiento que da el Tribunal a las cuestiones que suscitan los preceptos relativos al poder judicial me parecen desafortunados, comenzando ya por el mantenimiento de la distinción —a efectos de ampliar el espacio accesible a las opciones de asunción autonómica de competencias - entre administración de justicia propia e impropia. Pues la impropia no es sino la instrumental necesaria para la impartición de la justicia y, por tanto, parte componente de la materia administración de justicia en sentido estricto. A la luz de las consideraciones del Tribunal Constitucional sobre las implicaciones para el poder judicial del modelo territorial de la Constitución y la 
importancia que concede al principio de unidad incluso desde el punto de vista del gobierno de dicho poder, el desgaje de parte de la aludida materia resulta de todo punto desproporcionado y, por tanto, injustificado, incluso si se mide por el criterio más benévolo posible, el que, en lo competencial, aplica la propia doctrina constitucional a la relación entre lo principal y lo accesorio (así, por ejemplo, en materia expropiatoria o sancionadora y para predicar que lo segundo siga la suerte de lo primero). No digamos ya, por tanto, si se aplica el criterio que se emplea, sin discusión, a la expresada relación a los efectos de salvaguardar la división funcional del poder y que impide la diferenciación a propósito de la función legislativa y como materias distintas- de «la legislación y el control político del ejecutivo», de un lado, y «la gestión de los medios personales, administrativos y patrimoniales» de las Cámaras, de otro. Y ello, porque la disposición sobre la segunda es condición de la plena independencia en el desarrollo de la función constitucional propia del legislativo.

Más allá de la comentada determinación de la materia «administración de justicia», el tratamiento de la incidencia estatutaria en la organización de las instituciones de la instancia general del Estado viene obviamente prefigurado por la amplitud — desbordante de lo institucional- del contenido legítimo del Estatuto de Autonomía previamente asumida: éste no se ofrece circunscrito, en efecto, a las instituciones de autogobierno de la Comunidad Autónoma, capaz de extenderse, todo lo más, a las relaciones de éstas con las del poder central.

El empleo generoso, por no decir —aquí desde luego- excesivo, de la técnica de la interpretación conforme lleva a la Sentencia, en efecto, a una indebida compresión incluso de la competencia estatal plena sobre la materia administración de justicia en sentido propio o estricto por desconsideración absoluta de la potestad de organización inherente a la titularidad de la misma. De este modo:

$1^{\circ}$. Se entiende suficiente para avalar la regulación en el artículo 95 del Estatuto todo lo principial que se quiera— del Tribunal Superior de Justicia i) el dato de estarse ante una reproducción de lo previsto en el artículo 152.1 CE y ii) la posibilidad de la derivación del 152.1 CE que aquel Tribunal ha de ser competente, en principio, en todos los ordenes jurisdiccionales. Y sobre esta base se concluye que la simple referencia a la Ley orgánica del poder judicial deja suficientemente a salvo la competencia estatal.

Ocurre que la cuestión competencial no alude a la pertinencia técnica o no, ni a la corrección o no del contenido de la correspondiente regulación, sino, exclusivamente, a quien puede establecerla, extremo éste que se obvia completamente. Como se obvia la circunstancia evidente de que la reproducción de lo que dice la Constitución no enerva su invalidez competencial y su condicionamiento de lo que pueda disponerse por Ley orgánica estatal (tanto más cuanto se adentra en el terreno de la competencia del Tribunal aludido). So pena de privar al precepto de todo sentido y alcance, ya incluso la mera previsión estatutaria del Tribunal con determinación de su posición y su función principial traba, en efecto, la plena disposición sobre la organización judicial que implica necesariamente la competencia estatal plena sobre ella. Esa trabazón -aunque no apreciada- es admitida implícitamente por la Sentencia, cuando afirma que la remisión a la Ley orgánica estatal competente basta para despejar la cuestión en la medida en que deja a salvo la reserva a ésta de determinados aspectos (pero no todos, como queda dicho) de la organización del Tribunal, en concreto las de si es o no competente en todos los órdenes ju- 
risdiccionales; las competencias que en ellos se le atribuyan; la concreción de las consecuencias que se siguen de su condición de última instancia posible en Cataluña; y la determinación de los supuestos en que la resolución de los recursos extraordinarios de revisión legalmente previstos.

Esta generosa actitud interpretativa ${ }^{36}$ no es plenamente consecuente, al no ceder ni ante la evidencia — cual sucede en los dos últimos extremos aludidos- de la «obligación» de la Ley orgánica para con las previsiones estatutarias ${ }^{37}$ del agotamiento en algún caso de los recursos posibles en el Tribunal Superior y en la atribución necesaria a éste, en algún supuesto, del recurso extraordinario de revisión. Cuando se enfrenta, en efecto, a la referencia estatutaria a la competencia reservada al Tribunal Supremo para la unificación de doctrina, el criterio interpretativo se torna, sin base objetiva que la justifique, mas rigurosa y estricta, sin perjuicio de no llegar a producir declaración de inconstitucionalidad gracias a la aplicación, una vez más, de la técnica de la interpretación conforme.

$2^{\circ}$. En línea de continuación del amplísimo criterio interpretativo expuesto, se da por buena la previsión estatutaria (art. 96) de la condición de Fiscal Superior de Cataluña del Fiscal Jefe o la Fiscal Jefa del Tribunal Superior de Cataluña; la atribución al mismo de la representación del Ministerio Fiscal en Cataluña; su designación «en los términos» que establezca su estatuto orgánico, pero con publicación de su nombramiento - no obstante y por orden del Presidente de la Generalitat - en el Diario Oficial de la Generalitat; su deber de envío de una copia de la memoria anual al Consejo Superior de Justicia y al Parlamento de Cataluña, así como de presentación de la misma ante éste dentro de los seis meses siguientes al día en que la haga pública, y su habilitación para celebrar convenios con la Generalitat. Y ello, a pesar de que aquí ya no existe siquiera la apariencia de cobertura de la «reproducción» de previsiones constitucionales. No es sólo que el órgano de que ahora se trata no esté previsto por la norma fundamental, es que la simple previsión estatutaria de su necesaria existencia choca con la configuración por aquélla del Ministerio Fiscal como institución perteneciente al poder judicial que ejerce sus funciones (constitucionalmente también especificadas) por medio de órganos propios conforme, entre otros, a los principios de unidad de actuación y dependencia jerárquica (art. 124.2 CE). No hay espacio aquí, ni siquiera interpretativo, para aceptar condicionamiento alguno de la potestad de organización a actuar precisa y únicamente en sede del estatuto orgánico de Ministerio Fiscal y por Ley obviamente estatal. Salvo que se niegue a las previsiones estatutarias toda significación y virtualidad (lo que no parece posible):

— La atribución de la condición de Fiscal Superior de Cataluña no es susceptible de ser rebajada a un mero cambio de denominación, que, en todo caso, supone de suyo una lesión de la potestad estatal de organización: la de la decisión misma de la existencia o no del órgano primero (existencia no impuesta por la Constitución) y luego también la de su denominación (cuyo cambio no es del todo inocuo). Pues la cuestión competencial, re-

36 Que no se observa, al menos con igual claridad y parecido alcance, en la que refleja la doctrina del Tribunal Constitucional cuando la cuestión de plantea en los términos inversos y se trata, por tanto, de la salvaguarda de la potestad de autoorganización de las Comunidades Autónomas en las materias de su competencia plena.

37 El condicionamiento de la Ley orgánica estatal luce en la literalidad del artículo 95 del estatuto de Autonomía, pues la remisión de éste a aquélla no es sin más, sino solo «en los términos» establecidos por ella. Lo que significa priva a ésta el si de la previsión, dejándole solo el cómo de la misma. 
cuérdese, alude no al qué, sino al quién. De ahí que no se alcance a comprender cómo el hecho de que la no afección estatutaria del procedimiento de designación puede salvar la previsión comentada.

- El directo conferimiento a un órgano propio del Ministerio Fiscal (único en todo el territorio estatal) de la representación de éste en Cataluña y de la habilitación para celebrar convenios con la Generalitat constituye prueba palmaria de la invasión de la potestad de organización reservada constitucionalmente al Estado central, el cual es libre en ejercicio de ella- para otorgar o no al órgano de que se trata relevancia externa y, en su caso, la facultad general de representar a la institución y de celebrar convenios que la vinculen. La cuestión tiene la suficiente trascendencia para la organización y el funcionamiento del Ministerio Fiscal, pues, cómo para no poder ser despachada, como hace la Sentencia, con la afirmación de que la referencia a la función de representación «... se compadece sin dificultad con esa remisión a la disciplina del estatuto orgánico...», resultando un verdadero contrasentido el añadido de que «... abunda, por lo demás, en los principios de unidad y jerarquía que le son característicos». Tanto más cuanto que la facultad de representación se traduce concretamente nada menos que en la facultad-deber de presentar la memoria anual de la Fiscalía en Cataluña ante el Parlamento catalán. No parece que pueda negarse que aquí el estatuto impone directamente un deber a un elemento de la estructura interna del Ministerio Fiscal, que queda desde luego, además, fuera de la disposición tanto del estatuto orgánico (que ha de asumir e incorporar el deber, si quiere ser consecuente con el Estatuto de Autonomía), como de la facultad de dirección del Fiscal General del Estado en cuanto superior jerárquico.

- La prescripción de la publicación del nombramiento en el Diario Oficial de la Generalitat por Orden del Presidente de ésta, aunque pueda interpretarse que no impone condicionamiento alguno previo — ni siquiera de orden procedimental — a la facultad de resolución sobre el nombramiento, impone un trámite ex post al procedimiento de designación, que solo puede entenderse como requisito autonómico para la efectividad de ésta, es decir, el desarrollo de las funciones correspondientes en Cataluña. Y con ello un claro condicionamiento de la potestad de organización estatal en la materia. Salvo que los no concluyentes términos de la interpretación conforme verificada por el Tribunal Constitucional signifiquen que cabe la simple inobservancia de la previsión estatutaria, al no poder seguirse de ella efectos algunos. Hipótesis ésta que no diría mucho tampoco del cumplimiento de la función propia del Tribunal Constitucional.

$3^{\circ}$. La regulación estatutaria del Consejo de Justicia de Cataluña implica ya -incluso prescindiendo de la cuestión de su disconformidad con la regulación constitucional del gobierno del poder judicial — una penetración tan evidente e importante en el campo organizativo del Estado en sentido estricto que ni el esfuerzo interpretativo es capaz de salvar del juicio de inconstitucionalidad. No obstante, permanece la insensibilidad del Tribunal Constitucional respecto de la integridad de la potestad de organización del poder central en la materia, pues su reacción frente a la regulación estatutaria obedece exclusivamente a la afirmación de su contradicción con la configuración por la norma fundamental del Consejo General del Poder Judicial, defendida con rigor a diferencia de lo sucedido con la del Ministerio Fiscal. Al dejar de lado aquí la cuestión de quién está constitucionalmente habilitado para concretar la organización del Consejo General del Poder Judicial, el Tribunal soslaya desde luego toda inconse- 
cuencia frontal con respecto a sus pronunciamientos previos sobre el Tribunal Superior y su Fiscal (en los que evita, por demás, el empleo o, incluso, toda referencia expresa y directa a la organización como inherente a la competencia en la materia). Pero, siendo indudable que la razón última de su conclusión de inconstitucionalidad es de índole organizativa, tal inconsecuencia, aunque no manifiesta, es inevitable. Pues lo que ahora es por su cantidad y alcance evidente, no deja de serlo cuando su cantidad y alcance es menor: en todos los casos la cuestión implicada es cualitativa, la de quién tiene la competencia para regular.

Lo más destacable, con todo, es que parte de la regulación estatutaria logra, a pesar de todo, eludir el juicio de inconstitucionalidad mediante la transmutación, por obra del Tribunal Constitucional, del Consejo, que lo es de gobierno del poder judicial, de órgano desconcentrado del Consejo de Gobierno del Poder Judicial, es decir, órgano estatal en sentido estricto, pero de ámbito territorial autonómico, en órgano autonómico (órgano de la Comunidad Autónoma) con competencia, por ello, ya no en materia de la administración de justicia propia o en sentido estricto, sino sólo en la de la administración de justicia impropia, sobre la que recaen solo competencias de índole o naturaleza administrativa susceptibles de ser asumidas estatutariamente según la doctrina constitucional. En el caso, pues, en que la incidencia estatutaria ilegítima (competencialmente) en la organización estatal en sentido estricto es más clara y flagrante, es decir, cuando la técnica interpretativa, incluso llevada al extremo de sus posibilidades, no alcanza para el efecto de validación, la Sentencia no se arredra por penetrar en el terreno inseguro ${ }^{38}$ de la sustitución de la reconocidamente inequívoca voluntas legislatoris, haciéndolo con todas las consecuencias. El Consejo de Justicia de Cataluña que hoy puede y debe tenerse por vigente es un órgano de naturaleza, posición, función y competencias diferentes del establecido en la norma sometida al control constitucional.

Es lógico que el criterio del Tribunal Constitucional mantenga e, incluso, intensifique, en beneficio de la norma estatutaria, la expuesta tónica de amplitud y flexibilidad cuando se trata de la incidencia en la organización y el funcionamiento del complejo orgánico encargado, en la instancia central, de la función ejecutiva. Esa incidencia se articula sobre la prescripción de la participación (diversa) de la Generalitat que, si ciertamente plausible como previsión de una facultad (competencia) genérica y para los supuestos y en los términos en que en cada caso proceda (concretados en sede de la legislación procedente por razón de la materia), es mucho más discutible cuando se impone con carácter general, de modo inexcusable y no sólo por relación a los principios deducibles de la Constitución (sino, incluso, con especificación luego de sus términos en los diferentes supuestos), presuponiendo así que tal regulación es lógica emanación de la posición, es decir, el estatuto subjetivo de la entidad autónoma. Y lo es precisamente desde el punto de vista — de nuevo — del carácter y la función meramente institucionales del Estatuto de Autonomía. Por la misma naturaleza de las cosas, en el autogobierno no puede considerarse comprendida la determinación de las formas, los términos y el alcance de las (inevitables) relaciones con las instituciones generales, siquiera sea cuando tal determinación penetra en el campo de la organización de éstas (condicionando su potestad

38 Asumiendo, por ello, el riesgo ya señalado de traspasar el umbral de su función jurisdiccional propia. 
plena para establecerla), sino hasta en el de su competencia para establecer el régimen básico de aquellas relaciones ex artículo 149.1.18 CE.

De la redacción del artículo 174.3 del Estatuto se desprende con toda claridad que la participación autonómica que prescribe es, de un lado, general (en el doble sentido de comprender cualesquiera órganos y decisiones del Estado central y cubrir todas las formas — orgánicas y funcionales - posibles) y, de otro, universal (en el sentido de que cubre el entero ámbito competencial de la instancia autonómica, dependiendo su preceptividad solo de cualquier afección a cualquier competencia de ésta). Son estas características justamente las que incapacitan al argumento del carácter genérico e impreciso del precepto estatutario para desvirtuar su condicionamiento de la plenitud de la potestad de autoorganización del Estado central (solo restringible y efectivamente restringida por el marco constitucional). No es exacta, en efecto, la afirmación de que remite enteramente a ulteriores normas cuáles sean las instituciones y los organismos, así como los procedimientos de toma de decisiones, en los que deba verificarse la participación, ni mucho menos la definición misma de esta última. Aparte el hecho de que el propio Estatuto es una de esas normas y en él se precisan las consecuencias de la previsión comentada, siendo así que tal remisión a si mismo es cuestionable por las razones que nos son conocidas. Por esta razón tampoco es convincente la mera afirmación de que las participaciones orgánica y funcional han de dejar a salvo la titularidad de las competencias estatales implicadas, pues la contradice la propia regulación estatutaria, que sin duda condiciona dichas competencias en punto al menos al sí y al qué de la participación. El propio Tribunal Constitucional estima suficiente, en efecto, que quede a salvo de la predeterminación estatutaria la sustanciación de la participación en la integración en órganos decisorios (aceptando, así, la que afecta a la sustanciación en órganos de consulta y asesoramiento y la procedimental de idéntico alcance). Prueba definitiva es la conclusión interpretativa: el sentido del precepto consiste en la previsión de una participación orgánica y procedimental que ha de ser regulada por la legislación estatal con el límite de no poder sustanciarse en órganos decisorios, ni menoscabar el libre y pleno ejercicio de las competencias estatales (ergo hay un efecto general de imposición de esa regulación y, por tanto, de condicionamiento y también un efecto específico de mayor alcance).

La reserva estatutaria de no vinculación de la Generalitat por las decisiones adoptadas en el marco de los mecanismos multilaterales de colaboración voluntaria tampoco admite la interpretación conforme que hace el Tribunal Constitucional desde la simple doble apelación a su condición de efecto justamente de la voluntariedad y la no afección por la colaboración de la titularidad de la competencia. La voluntariedad de la colaboración no se agota en la no vinculación, pues la colaboración puede generar organizaciones para la gestión en común (por ejemplo un consorcio) respecto de la que no cabe predicar ya, sin más, tal efecto (sin perjuicio de la posibilidad de abandono de la organización, cosa que es distinta). Y lo mismo sucede con la no afección de la titularidad de la o las competencias comprometidas en la colaboración, pues la retención de la titularidad nada dice del destino del ejercicio. El problema dista de localizarse en los expresados extremos; radica única y exclusivamente en si la norma estatutaria, pudiendo desde luego contemplar — en cuanto norma institucional y a titulo de mero derecho de participación en las fórmulas multilaterales que se 
concreten al efecto (fuera del Estatuto mismo) - las relaciones con el resto de la estructura estatal, es sede posible de la fijación de limitaciones y restricciones a sus consecuencias sobre las competencias comprometidas o si, más bien, la sede de la regulación de tales fórmulas es, necesariamente, la Ley general reguladora de las concretas fórmulas de colaboración.

Crítica más severa merece la resolución de la operación interpretativa de la participación autonómica en la designación de Magistrados del Tribunal Constitucional y miembros del Consejo General del Poder Judicial. Aquí la mayor intensidad en la incidencia estatutaria en la competencia estatal, lejos de corresponderse con una argumentación más aquilatada, se despeja sorprendentemente con la conceptuación del precepto estatutario enjuiciado como simple expresión de un mero propósito, diríase que una oferta de colaboración, por razón, además, de un «especial» interés para las Comunidades Autónomas en cuanto partes del Estado ${ }^{39}$. Lo que supone, en realidad, desposeer a la norma estatutaria en este punto de todo contenido verdaderamente preceptivo, como parece desprenderse de su interpretación final en el sentido del condicionamiento de la participación autonómica, no solo en sus procedimientos, sino en su misma existencia, a lo que dispongan las Leyes orgánicas estatales correspondientes. Este resultado es, así, la consecuencia inevitable de la implícita imposibilidad inherente al discurso seguido del planteamiento de la única cuestión también aquí verdaderamente pertinente: la de si la norma estatutaria puede establecer este tipo de previsiones.

Así lo confirma la inmediata interpretación conforme de la extensión de idéntica participación a un elenco variado de organismos estatales, en la medida en que se entiende que ha de tener lugar «en los términos» de la legislación aplicable. Pues ha de hacerse descansar, para evitar reconocer el condicionamiento de la competencia estatal que, cuando menos en punto al «si», es decir, a la participación misma, evidentemente supone, sobre la afirmación — bien desnaturalizadora del precepto interpretado por frontalmente contradictoria con su tenor literal, bien irreal ${ }^{40}$ - de que tal remisión a la legislación aplicable implica que al Estado central corresponde no sólo la precisión de los

39 La utilidad argumentativa de la referencia a este especial interés habría requerido una mayor elaboración. Pues no es de suyo evidente el encuadre de dicho interés en el círculo de intereses trazado por el artículo 137 CE, que la doctrina del Tribunal Constitucional vincula a la esfera de las competencias asumibles por aquéllas (vinculación en la que se insiste, en todo caso, en el fundamento 118 de la misma Sentencia comentada), toda vez que, entonces, habría que reconocerlo también, con las modulaciones que se quiera, a las entidades de la Administración local. Tampoco la participación asegurada constitucionalmente a las Comunidades Autónomas en la Cámara territorial de las Cortes Generales es aducible sin más como confirmación «mediata» de la viabilidad de una participación directa e individualizada de que aquí se trata; antes al contrario, representa en principio un argumento en contra (la participación constitucionalmente querida ya se produce justamente a través de la orgánica en el Senado).

La posición del Tribunal Constitucional — consecuencia directa aquí, una vez más, de su amplísima concepción de la función y el contenido de la norma estatutaria - parece más bien condicionada en este punto por la previa modificación, en sede de su Ley orgánica reguladora, del procedimiento de designación de los Magistrados del Tribunal Constitucional.

40 Ejemplo paradigmático de la irrealidad a la que aboca el recurso a la interpretación conforme lo proporciona el resultado del examen de la disposición adicional segunda del Estatuto: siendo diáfana la voluntad prescriptiva de la disposición, resulta de todo punto inane la dilución interpretativa de su alcance a una «forma de actuar» que, paradójicamente, permite la toma de la decisión estatal con entera libertad aunque con obligación de motivación (lo que implica que no es enteramente libre). 
«términos» de la participación (su alcance y su específico modo de articulación), sino incluso hacerla o no efectiva en cada caso «con entera libertad».

Reincidencia en el recurso al refugio en argumentaciones periféricas es observable cuando la participación alcanza el punto de la creación de una estructura orgánica de colaboración «bilateral». El mayor énfasis se pone, en efecto e innecesariamente, pero significativamente, en lo evidente: de un lado, en que no se produce un —en todo caso imposible - compromiso del entero Estado, sino solo de la parte de éste constituida por las instituciones generales o centrales; y, de otro, en que se está ante una previsión limitada a la creación de un órgano destinado a ser el marco general y permanente de las relaciones recíprocas, no excluyente de otros (multilaterales) y destinado a cumplir funciones de mera deliberación, propuesta y, en su caso, adopción de acuerdos para la concertación de las correspondientes competencias ${ }^{41}$. Se evita, de nuevo, la única cuestión pertinente: dado que se trata de un órgano que compromete - en su organización y funcionamiento y por razón de su participación en él— a las referidas instituciones (y, si se quiere, exclusivamente al Gobierno), ¿es el Estatuto la sede idónea para abordar las relaciones Generalitat-Estado central limitándose a establecer un marco orgánico general y permanente para el desarrollo de aquéllas sin alterar el régimen de las respectivas competencias? Curiosamente, de haberse planteado tal pregunta, la respuesta habría podido ser, a mi juicio, rotundamente positiva ${ }^{42}$, en cuanto determinación genérica conexa con, si no perteneciente a, la regulación institucional del autogobierno. La omisión es en este punto, por tanto, más elocuente que el planteamiento expreso.

No puede concluirse este punto sin una observación final que me parece necesaria para evitar cualquier malentendido: mis observaciones apuntan exclusivamente a la inidoneidad de la norma estatutaria, por razón competencial, como sede de las previsiones comentadas, por deber predicarse la idoneidad de la legislación pertinente (dictada, en su caso, con participación de la Generalitat). En modo alguno son referibles, por tanto, a la constitucionalidad misma de las soluciones en dichas previsiones formalizadas. En este contexto no puede dejar de llamarse la atención, por ser llamativa, sobre la distinta vara de medir y, por tanto, el diferente criterio empleado en el examen, desde la perspectiva del respeto de la potestad de organización del Estado central, del régimen estatutario de las relaciones Generalitat-Estado y, a la hora de la preservación de la potestad de organización autonómica (incluso ya en materia de Administración pública), de cualesquiera regulaciones estatales con incidencia en ella. Así resulta de la propia Sentencia cuando, a propósito de la impugnación del artículo 150 del Estatuto, recuerda su doctrina en los siguientes términos:

»Las Comunidades Autónomas tienen la potestad exclusiva de crear modificar y suprimir los órganos, unidades administrativas o entidades que configuran sus respectivas Administraciones, de manera que pueden conformar libremente la estructura orgáni-

41 Sin que las decisiones o los acuerdos adoptados en su seno — en tanto que órgano de cooperación voluntaria- puedan en modo alguno impedir el libre y pleno ejercicio por el Estado central de sus propias competencias.

42 Con independencia ahora de su habría debido hacerse o no alguna matización en cuanto a las funciones del órgano. 
ca de su aparato administrativo, debiendo el Estado abstenerse de cualquier intervención en este ámbito (STC 50/1999, de 6 de abril; FJ 3)» [la cursiva es mía].

5. El tratamiento, ciertamente extenso, que la Sentencia dedica a las llamadas cuestiones competenciales, ¿Qué comentarios le suscita a Vd.?

\section{Roberto BlanCo VALDÉS}

Sí, es verdad, el tratamiento del TC en este decisivo ámbito es tan extenso (se dedican a la cuestión los fundamentos jurídicos 57 a 109, de un total de 147), que debemos ser aquí necesariamente concisos, refiriéndonos sólo a los aspectos esenciales de la Sentencia. Dejando, por tanto, de lado la cuestión de la constitucionalidad o no de competencias concretas, la Sentencia debía resolver, a la postre, si eran o no constitucionales los que ya hace tiempo denominé blindaje por definición o fijación y blindaje por descripción («Blindaje competencial e indefensión constitucional», en Claves de Razón Práctica, $\left.\mathrm{n}^{\circ} 176,2007\right)$. Con el término blindaje por descripción me refería a la extrema minuciosidad con la que se describen en el nuevo Estatuto los ámbitos de actividad concretos que comprende cada uno de los numerosos títulos materiales atribuidos a la Generalidad, según aquellos constan en el capítulo II del título IV. Pero el blindaje estatutario consistía, además, en una categorización general de los diversos tipos de competencias, categorización que tenía por objeto delimitar, por exclusión, la presencia del Estado en territorio catalán mediante la fijación de la extensión material de los tipos de competencias atribuidos a la Generalidad: es lo que denominé en su día blindaje por definición o fijación de las diversas tipologías competenciales (exclusivas, compartidas y ejecutivas), que se opera en el capítulo I del título IV del nuevo texto estatutario. Pues bien, la consideración que merecen ambas técnicas al TC es muy diferente, según cabe deducir de su Sentencia 31/2010.

En relación con el blindaje por definición o fijación, el TC ha establecido, como se sabe, una interpretación constitucionalmente adecuada respecto de la definición del contenido de las competencias exclusivas y ejecutivas y declarado parcialmente inconstitucional la regulación de las compartidas. Los principios básicos que han llevado al Tribunal a adoptar decisiones que, por mi parte, considero evidentes y que comparto plenamente son los siguientes: que los Estatutos no pueden proceder a definir las categorías constitucionales; que los Estatutos pueden atribuir una competencia legislativa sobre determinada materia, pero que lo «que haya de entenderse por «competencia» y qué potestades comprenda la legislativa frente a la competencia de ejecución son presupuestos mismos del sistema en que el Ordenamiento consiste y, por tanto, reservados a la norma primera que lo constituye»; y, finalmente, que «en su condición de intérprete supremo de la Constitución, el Tribunal Constitucional es el único competente para la definición auténtica —e indiscutible- de las categorías y principios constitucionales». Va a ser a partir de tales principios como el tribunal sostendrá que el artículo 110 del Estatuto según el cual la Generalitat posee, en el ámbito de sus competencias exclusivas, de forma íntegra las potestades legislativa y reglamentaria y la función ejecutiva, correspondiendo 
únicamente a la Generalitat el ejercicio de esas potestades y funciones, y añadiendo el precepto que el derecho catalán, en materias de competencia exclusiva de la Generalitat, es aplicable en su territorio con preferencia sobre cualquier otro- sólo es constitucional si se interpreta en el sentido de que «no impide el ejercicio de las competencias exclusivas del Estado [...], sea cuando estas concurren con las autonómicas sobre el mismo espacio físico u objeto jurídico, sea cuando se trate de materias de competencia compartida, cualquiera que sea la utilización de los términos «competencia exclusiva» o «competencias exclusivas» en los estantes preceptos del Estatuto, sin que tampoco la expresión «en todo caso», reiterada en el Estatuto respecto de ámbitos competenciales autonómicos tenga otra virtualidad que la meramente descriptiva ni impida por sí sola, el pleno y efectivo ejercicio de las competencias estatales». Esta interpretación, que de hecho vacía en gran medida de contenido un precepto cuyo manifiesto objetivo era evitar justamente la que el TC considera su única interpretación valida, resulta plenamente coherente, además, con el sentido que ha ido adquiriendo la expresión competencias exclusivas del artículo 149.1 de la Constitución a lo largo de los años de desarrollo del Estado autonómico, una expresión que, ciertamente, no ha impedido que la mayor parte de las que nuestra ley fundamental define como exclusivas hayan acabado configurándose a fin de cuentas como competencias compartidas entre el Estado central y las Comunidades Autónomas. También en relación con el artículo 112 — que, al definir las competencias ejecutivas de la Generalitat, incluye dentro de su potestad reglamentaria, la aprobación de disposiciones para la ejecución de la normativa del Estado- opera el TC de modo similar: y así, tras aclarar, con toda la razón, que la normativa del Estado comprende «con naturalidad las normas estatales adoptadas en el ejercicio de la potestad reglamentaria», dispone que lo que no cabría en ningún caso, según una interpretación constitucionalmente valida, es que la competencia ejecutiva de la Generalitat se ejerza, a partir de la normativa (legal y reglamentaria) del Estado, «no sólo como función ejecutiva stricto sensu, sino también como potestad reglamentaria de alcance general». De este modo, será sólo en relación con la definición de las competencias compartidas con el Estado en relación con las que el TC considerará insalvable, por la vía de la interpretación, la prescripción estatutaria. El artículo 111 dispone, al respecto, que en las materias que el Estatuto atribuye a la Generalitat de forma compartida, corresponde a aquella la potestad legislativa y reglamentaria y la función ejecutiva en el marco de las bases que fije el Estado, bases que la norma define «como principios o mínimo común denominador normativo en normas con rango de ley, excepto en los supuestos que se determinen de acuerdo con la Constitución y el presente Estatuto». Será justamente tal definición la que el TC entenderá inconstitucional y declarará nula en la medida en que «el precepto no se atiene estrictamente al concepto constitucional de las bases estatales, toda vez que las reduce a los «principios o mínimo común denominador normativo» fijados por el Estado «en normas con rango de ley», cuando es lo cierto que, conforme a nuestra jurisprudencia, siendo aquel el contenido que mejor se acomoda a la función estructural y homogeneizadora de las bases y esta la forma normativa que por razones de estabilidad y certeza le resulta más adecuada, no lo es menos que también es posible predicar el carácter básico de normas reglamentarias y actos de ejecución del Estado [...]». La posición del TC, a mi juicio ininpugnable, es, en suma, que el Estatuto, elevando a regla esencial una sola de las variables por él admitidas en la definición del concepto de 
bases estatales, «termina por definir el ámbito competencial del Estado», dado que «si las bases son «principios» o «normación mínima» no es asunto a dilucidar en un Estatuto sino sólo en la Constitución, vale decir; en la doctrina de este Tribunal que la interpreta».

Ahora bien, el mismo Tribunal que decide, con muy buen criterio jurídico-constitucional, ajustar seriamente el blindaje por fijación o definición, liquida, sin embargo, sin más trámites, las graves cuestiones jurídicas de fondo implicadas en lo que he llamado blindaje por descripción, cuestiones esas en las que aquí no puedo entrar con detalle y a las que en otro lugar me he referido en profundidad ( «Blindaje competencial e indefensión constitucional», en Claves de Razón Práctica, n 176, 2007). Ello resulta más sorprendente si se tiene en cuenta que también a través de esa modalidad de blindaje viene, sin duda, el Estatuto a definir, por exclusión, el ámbito competencial del Estado y a dilucidar, en una norma del todo inidonea para ello, una cuestión que sólo puede fijarse en la Constitución $\mathrm{y}$, en su caso, resolverse por medio de la doctrina de su intérprete supremo No lo aprecia de ese modo el TC, para quien nada se opone a que un Estatuto «utilice una técnica descriptiva de las materias y submaterias sobre las que la Comunidad Autónoma asume competencias siempre, obviamente, en el marco de la Constitución y respetando el límite de las competencias reservadas al estado ex articulo 149.1 CE». La clarísima debilidad del razonamiento del TC se pone de relieve cuando, tras tal afirmación, sostiene que al enjuiciar los artículos impugnados atributivos de competencias concretas él mismo deberá «comprobar si, en efecto, se reservan las competencias exclusivas reservadas al Estado, bien sobre la totalidad de una materia, bien sobre las submaterias eventualmente integrantes de un determinado sector material, en el entendido ya establecido de que la realidad el contenido y el alcance de unas y otras, sobre las que las competencias han de ejercerse, como los de estas mismas, serán siempre los que se desprenden de la Constitución interpretada por el Tribunal Constitucional». En contra de tal juicio del TC, parece evidente, sin embargo, lo que éste deja de lado en su razonamiento: que su jurisprudencia al respecto puede ser — y de hecho lo ha sido históricamente- cambiante y que convertir esa cambiante doctrina, en un determinado momento, en norma estatutaria es una manera de petrificarla sujetando al intérprete de la Constitución a un parámetro de referencia que a él sólo corresponde fijar en última instancia en caso de conflicto competencial e invadiendo, así, tanto las posibles competencias del Estado como las del legislador autonómico. Diré, finalmente, que en línea parcialmente coincidente con lo que ahora acabo de apuntar se manifiesta el voto particular presentado por el magistrado Jorge Rodríguez-Zapata Pérez, en especial en sus explicaciones $5^{a}$ y $7^{a}$.

\section{Raúl Canosa Usera}

Junto con lo simbólico y lo financiero, el denominado «blindaje» competencial formaba el núcleo de las pretensiones estatutarias y ha sido por completo desactivado por la STC 31/2010 que olvida lo dicho en la STC 247/2007. Si en esta sentencia y sin necesidad para resolver el pleito que se ventilaba (el derecho al agua proclamado en el Estatuto de Valencia) se incluye un largo obiter dictum que parecía preludiar la constitucionalidad del blindaje catalán, la STC 31/2010 omite ese precedente y sienta una doctrina que desarbola por completo el blindaje con pocas declaraciones de inconstitucionalidad 
pero con varias interpretaciones conforme, algunas llevadas al fallo, y que afectan a los más importantes preceptos competenciales estatutarios (en especial los artículos $111 \mathrm{a}$ 112) y, de una u otra suerte, a la mayor parte de ellos.

Se evitan así dos consecuencias: abrogar la jurisprudencia del TC en la materia y definir las competencias estatales desde un Estatuto. La primera podría haberse soslayado de haber perseverado la STC 31/2010 en la línea marcada por la STC 247/2007 que daba argumentos para avalar la mutación constitucional en ciernes. Si el TC cambiaba preventivamente su doctrina, entonces lo dispuesto en el Estatuto de Cataluña habría podido ser declarado constitucional, incluyendo el pretendido «blindaje». Por ello ha sido tan significativo lo que algunos han llamado involución de la interpretación del TC, porque éste no se ha atenido a lo dicho en la STC 247/2007, y el resultado ha sido devastador para el blindaje, ya que, si bien se ha admitido la técnica de la minuciosa descripción de las materias y submaterias, se ha dejado claro que esta función descriptiva del Estatuto no puede pretender delimitar ni material ni funcionalmente las competencias estatales que derivan directamente de la Constitución. Esto era lo que ocurría con el artículo 111 del Estatuto (ahora anulado) cuando disponía que las bases estatales habrían de atenerse a los principios o a un mínimo común normativo formalizado en normas con rango de ley, o cuando ampliaba el alcance de la potestad ejecutiva de la Generalidad para comprender la potestad reglamentaria general (artículo 112) que el TC cercena mediante una interpretación conforme.

El criterio general seguido por el TC es que los Estatutos atribuyen competencias a las CCAA concernidas pero no al Estado, y que, en consecuencia, no pueden definir las competencias estatales ni impedir (como se intentaba con la proclamada preferencia del Derecho catalán en materia de su exclusiva competencia) el despliegue de las competencias que el artículo 149.1 CE reserva al Estado. El TC se aparta, pues, de la tesis de la desconstitucionalización del modelo de Estado autonómico que sacó a colación en la STC 247/2007 y que permitía a un Estatuto reconstitucionalizar, para advertir que las competencias estatales provienen de la Constitución; su indeterminación constitucional - material y funcional — su apertura en suma, no puede ser cerrada o despejada en un Estatuto de autonomía sino únicamente por el poder de reforma constitucional o por el supremo intérprete de la Constitución. La mutación constitucional que preludiaba la STC 247/2007, sustentada en una expansiva interpretación de la función constitucional de los Estatutos, se ha truncado. Las cosas siguen, pues, como antes en lo que atañe a la definición de las competencias, tanto estatales como autonómicas, así que el Estado podrá seguir ejerciendo sus competencias que, bien es cierto, se deberán confrontar con un ámbito material autonómico catalán muy pormenorizado. Esto generará conflictos en cuya resolución no cabrá aplicar la preferencia a la inversa que el artículo 112.3 del Estatuto dispone sino mediante el arbitraje del TC.

\section{Francesc de Carreras Serra}

Uno de los principales objetivos del nuevo Estatuto era el aumento y garantía (el llamado «blindaje» frente a las presuntas erosiones del Estado) de las competencias de la Generalitat. Para ello el Estatuto optó, finalmente, por tres vías: definir los tipos básicos 
de competencias; especificar las competencias actuales en materias y submaterias para que, «en todo caso», petrificaran la situación actual; y limitar las competencias estatales al obligar al Estado a determinadas formas de colaboración en el ejercicio de sus propias competencias.

La sentencia, en sus importantes FJ 57 y 58, sienta los principios básicos de la distribución de competencias acuñados a lo largo de los años por la jurisprudencia constitucional y la práctica institucional. El resultado de la aplicación de dichos principios es la declaración de nulidad del art. 111 (el concepto de bases estatales) y la modificación, mediante interpretaciones conformes llevadas al fallo, de los artículos 110 (competencias exclusivas) y 112 (competencias ejecutivas). Con ello se deja claro que no puede haber petrificación legal alguna de la jurisprudencia constitucional; que la especificación de competencias de la Generalitat que formula el Estatuto (incluida la reiterada expresión «en todo caso» al referirse a las competencias que actualmente ya ejerce) tiene un valor meramente descriptivo, pero no prescriptivo; que el Estado es totalmente libre en el ejercicio de sus competencias, sin que los estatutos puedan condicionarlo; y que, en definitiva, la última palabra en la materia será aquella que establezca, en su caso, el Tribunal Constitucional. El alcance de todas estas consideraciones es transversal a todo el articulado del largísimo título IV (arts. 110-173) dedicado a las competencias.

Así pues, la sentencia, sólo mediante la nulidad de tres incisos y abundante interpretación conforme, aunque sólo llevando al fallo los aspectos clave, impide que se alcancen los objetivos competenciales del Estatuto que antes mencionábamos. Así lo ha admitido el profesor Carles Viver Pi-Sunyer, director del Institut d'Estudis Autonòmics: «En suma, puede concluirse que la sentencia desactiva prácticamente todas las novedades que pretendía introducir el Estatuto en este ámbito [el de las competencias]. La situación después de la sentencia será la misma que existía antes de aprobarse el texto estatutario».

\section{MAR CARRILlo LóPEZ}

En realidad la extensión de los fundamentos jurídicos sobre competencias (Tit. IV EAC) es más formal que otra cosa, puesto que la sentencia manifiesta aquí su carácter más apodíctico y, por tanto, un grado de argumentación que es más bien limitado. Y lo es en relación con uno de los pilares esenciales de la reforma estatutaria, como era - junto al sistema de financiación- el destinado a la determinación de las competencias (art. $147.1 \mathrm{~d})$ CE.

La determinación de las competencias que llevó a cabo el Estatuto estaba destinada a establecer una delimitación funcional y material a través del desglose de las submaterias que integran los diversos ámbitos competenciales. En ningún caso cabe deducir que el Estatuto definiese lo que son las competencias a ejercer por la Generalitat, sino a describir lo que ya establece la Constitución en relación a la función legislativa, reglamentaria y ejecutiva. Por esta razón, la sentencia presenta un carácter preventivo cuando se pregunta sobre el tema y responde afirmando: «qué sea legislar, administrar, ejecutar o juzgar; cuáles son los términos de relación entre las distintas funciones normativas (...) (...) son cuestiones que, por constitutivas del lenguaje en el que ha de entenderse la voluntad del constituyente, no pueden tener otra sede que la Constitución formal, ni más sentido que el prescrito por su intérprete su- 
premo (art. 1.1 LOTC» (FJ 57). Y éste es un obiter dictum perfectamente innecesario de la sentencia.

En realidad la determinación precisa del contenido formal y material de las competencias, respondía a la necesidad de evitar los efectos generados en la aplicación de una determinada concepción del sistema constitucional de distribución de competencias, que ha disminuido de forma notable la capacidad normativa del legislador autonómico. A través de dos vías: una, el legislador estatal a través de la interpretación expansiva del alcance que debía tener su legislación básica (art.149.1 CE), ha venido restringiendo el margen de maniobra del Parlamento autonómico; y la otra, que ha operado de forma simultánea a la primera, se ha producido través de la reiterada invocación estatal de los títulos horizontales que le atribuyen la competencia exclusiva (especialmente, los previstos en los artículos 149.1 .1 y 13) sobre materias genéricas o transversales, lo que ha servido para diluir la competencia normativa autonómica sobre una competencia propia $^{43}$.

Pero, la respuesta dada por la STC 31/2010 a esta novedad estatutaria ha enervado el armazón jurídico que pretendía garantizar el contenido de las competencias determinadas por el Estatuto. Sus argumentos se encuentran en los FFJJ 57 a 61 relativos al Cap I del Título IV, en los que se contienen dos resoluciones interpretativas sobre las competencias exclusivas (art. 110) y ejecutivas (art. 112) y una declaración de inconstitucionalidad y nulidad que afecta a una parte del artículo 111, relativo a las competencias compartidas.

La decisión del Tribunal sobre las competencias exclusivas del artículo 110 EAC ha sido de carácter interpretativo, pero sus efectos son demoledores sobre las pretensiones de la reforma estatutaria. Como apuntaba con anterioridad, el objetivo de la misma era asegurar la exclusividad de las competencias autonómicas. Se trataba con ello de evitar que en las submaterias resultantes del desglose de las materias competenciales principales no afectadas por la legislación básica estatal, ésta última no incidiese sobre su contenido ya que lo había hecho sobre la materia principal. Así cobraba sentido jurídico el significado de la garantía contenida en la cláusula «en todo caso» prevista en una buena parte de las competencias que específicamente se concretan en el Cap. II del Título IV. Pero el criterio adoptado por el Tribunal, aunque formalmente excluye la inconstitucionalidad del artículo 110 y su proyección evidente sobre todo el Cap. II, no hay duda que materialmente desactiva sus objetivos de preservación de las competencias. El Tribunal es muy explícito cuando limita el alcance de la exclusividad al afirmar que el artículo 110 es constitucional siempre que: 1) no impida el ejercicio de las competencias exclusivas del Estado (art. 149.1 CE); 2) ya sea cuando sus competencias concurran con las autonómicas sobre el mismo espacio u objeto jurídico; 3) o cuando se trate de materias propias de competencias compartidas, cualquiera que hayan sido los términos que haya utilizado el Estatuto para calificarlas; y 4) sin que, «la expresión «en todo caso» reiterada en el Estatuto res-

43 Albertí Rovira, E.. «El blindatge de les competències i la reforma estatutària», Revista Catalana de Dret Públic, na31, 2005, págs. 109-136;

Viver Pi-SunYer, C., «En defensa de los Estatutos de Autonomía como normas jurídicas delimitadoras de competencias. Contribución a una polémica jurídico-constitucional», en RuIz-Rico RuIz, G., (Coord.). La reforma de los Estatutos de Autonomía. Actas del IV Congreso de la Asociación de Constitucionalistas de Espanya, Tirant lo Blanch, 2006, págs. 45-75. 
pecto de ámbitos competenciales autonómicos, tenga otra virtualidad que la meramente descriptiva ni impida, por sí sola, el pleno y efectivo ejercicio de las competencias estatales». (FJ 60). Por lo tanto, la cláusula «en todo caso» que desglosa las submaterias que integran la materia principal, no pasa de ser una concreción material sin fuerza vinculante para el legislador estatal el cual, en todo caso, siempre podrá incidir sobre las mismas. Esta es la regla general, con independencia de que la competencia de la Generalitat sea exclusiva o compartida ${ }^{44}$.

Este planteamiento del Tribunal se inserta en la lógica que preside toda la sentencia, de reducir el alcance del Estatuto como norma jurídica integrante del bloque de la constitucionalidad, que había de ser parámetro, junto con la Constitución, para la determinación de las competencias estatutarias. No es así puesto que la STC 31/2010 (FJ 57 y ss), sienta el criterio por el que en la tarea de delimitación de los ámbitos competenciales, han de ser la Constitución y su propia interpretación jurisdiccional los únicos referentes a tener en cuenta, dejando al Estatuto en una condición desvalorizada respecto de lo que pueda establecer sobre los títulos competenciales. Y, por supuesto, se rechaza que en el ámbito competencial el Estatuto, como complemento de la Constitución, presente una dimensión materialmente constitucional. Para la STC 31/2010, ello no pasa de ser una posición doctrinal o académica (F J 3). La conclusión es que con esta concepción se degrada del Estatuto como norma y se modifica el criterio propugnado por la STC 247/2007, en el que sostenía la concepción de los Estatutos como normas subordinadas a la Constitución, que expresaban la concurrencia de diversas voluntades en su proceso de elaboración (paccionadas) y que presentaban un valor complementario en la determinación de las competencias.

b) En lo que concierne a las competencias compartidas, la sentencia declara la inconstitucionalidad de una parte del art. 111 EAC. No cabe duda que las competencias compartidas han sido un punto de referencia para hacerse una idea cabal acerca del alcance efectivo de la autonomía política de las CCAA. Pero ha sido un hecho contrastado que el legislador estatal sobre la normativa básica se ha mostrado muy expansivo en la determinación del contenido material de las bases; y formalmente tampoco ha tenido muchas reservas en hacer uso de la potestad reglamentaria e, incluso, de los actos de ejecución para determinar la normativa básica. Y todo ello sin perjuicio de las advertencias en sentido contrario formuladas por el Tribunal Constitucional desde la STC 69/1988.

Precisamente, y acogiéndose a esta doctrina y al objeto de dotarse de una mayor garantía para preservar las competencias, la reforma estatutaria de 2006 pretendió incorporar esta jurisprudencia constitucional sobre el concepto formal de bases en el artículo 111, con las excepciones establecidas por la Constitución y el Estatuto. Los términos en los que se expresaba el Estatuto establecían que las potestades normativas de la Generalitat se tenían que desarrollar «... en el marco de las bases que fije el Estado, como principios o mínimo común normativo en normas con rango de ley, excepto en los supuestos que se determinen de

44 Sobre la clàusula «en todo caso», veáse el Dictamen del Consell Consultiu de la Generalitat de Catalunya número 269, de 1 de septiembre de 2005, fundamento VI.2.A (relativo a la Proposición de Ley Orgánica por la que se establece el Estatuto de autonomía de Catalunya y se deroga la Ley Orgánica 4/1979, del 18 de diciembre, del Estatuto de autonomía de Catalunya. 
acuerdo con la Constitución y con este Estatuto» (art. 111 EAC) ${ }^{45}$. Sin embargo, a pesar de la expresa excepción que el Estatuto incorpora, una excepción que remitía no sólo a la Constitución y al Estatuto, sino lógicamente también a la interpretación que de la misma hiciese el Tribunal Constitucional, la sentencia interpreta que el precepto estatutario no se ajusta estrictamente al concepto constitucional de bases estatales. Su argumento afirmando que el Estatuto, «las reduce a» los principios o mínimo común normativo» fijados por el Estado «en normas con rango de ley», cuando es lo cierto que, conforme a nuestra jurisprudencia, siendo aquél el contenido que mejor se acomoda a la función estructural y homogeneizadora de las bases y ésta la forma normativa que, por razones de estabilidad y certeza, le resulta más adecuada (por todas, la STC 69/1988, de 19 de abril), no lo es menos que también es posible predicar el carácter básico de normas reglamentarias y de actos de ejecución del Estado (STC 235/1999, de 16 de diciembre)...» (FJ 60). Lo cual lleva de inmediato a preguntarse sobre cuál es la diferencia susbstancial que el Tribunal ha detectado, entre esta jurisprudencia que él mismo rememora y la previsión establecida en el artículo 111 del Estatuto, para concluir con una solución jurisdiccional tan extrema como es la inconstitucionalidad y nulidad del precepto. Extrema hasta el punto de que parece ignorar que tal como el artículo 111 fue aprobado en su redacción definitiva, ya ampliaba considerablemente las excepciones al uso de la ley formal como instrumento normativo para fijar las bases estatales a lo que de forma genérica - y no ya expresa, como establecía el texto inicialmente aprobado por el Parlamento catalán- establezca la Constitución y el Estatuto. Esa remisión en abstracto del art. 111 a ambas normas y, por tanto, a la interpretación de la excepción que hiciese el Tribunal Constitucional, dejaba las cosas en el mismo punto que las había fijado la STC 69/1988 a la que la STC 31/2010 se remite constantemente. Dicho de otra manera, la preocupación por los presuntos excesos susceptibles de inconstitucionalidad —a mi juicio inexistentes ya en el texto inicial -suscitados por el art. 111 en la redacción dada por el Parlamento de Cataluña, habían quedado desactivados con la redacción final dada al citado artículo en la reforma estatutaria.

Pues bien, a pesar de todo ello, para el Tribunal la respuesta a la incoherencia de declarar la inconstitucionalidad del art. 111 hasta aquí descrita, la encuentra al interpretar que, en realidad, los casos en los que la ley de las Cortes Generales no ha de ser la vía para la fijación de la legislación básica estatal no pueden ser entendidos «... como pura excepción al criterio que para el art. 111 EAC constituye la regla de principio (base principal o de mínimo normativo, formalizada como ley), sino como elementos de la definición del contenido y alcance de la competencia atribuida al Estado cuando éste es el titular de la potestad de dictar las bases de la disciplina de una materia determinada» (FJ 60). En consecuencia, la conclusión de esta interpretación parece obvia: la STC 31/2010 consolida la práctica llevada a cabo por el Estado, que el Tribunal había censurado desde la STC 69/1998 (FJ 5) — cuya doctrina ahora es revisadapero que las Cortes Generales y el Gobierno central habían puesto en práctica reiteradamente a lo largo de los treinta años del Estado de las autonomías. Y es ésta y no otra la que ha permitido que la determinación formal de las bases no esté sometida a un criterio for-

45 En la redacción del texto del artículo 111 aprobada por el Parlamento de Catalunya el 30 de septiempre de 2005 (BOPC, núm. 224, de 3 de octubre de 2005) se establecía un redactado ligeramente distinto pero de menor alcance en cuanto a las excepciones al empleo de la ley formal para determinar las normas básicas: «(...) en el marco de los principios, los objetivos o los estándares mínimos que fije el Estado en normas con rango de ley, excepto en los casos que establezcan expresamente la Constitución y este Estatuto». 
mal previo, sino más bien a la libre disposición del Estado de hacerlo mediante ley formal, reglamento administrativo o acto de ejecución, según proceda. En consecuencia, la función complementaria del Estatuto respecto de la Constitución, como norma integrante del bloque de la constitucionalidad, para la plena determinación de las competencias, queda diluida en favor del legislador estatal que predetermina el alcance de las bases.

c) Finalmente, respecto de las competencias ejecutivas (art. 112 EAC) el Tribunal ha emitido una sentencia de carácter interpretativo, cuyos efectos dejan las cosas tal como estaban antes de la reforma. Este precepto pretendía incorporar a las competencias ejecutivas de la Generalidad el ejercicio de la potestad reglamentaria con efectos ad extra, cuando desarrollara la normativa del Estado y no sólo los reglamentos internos o autoorganizativos. Pero el Tribunal niega este objetivo fundamentándose -una vez más- en su jurisprudencia anterior (STC 51/2006, FJ 4) como parámetro interpretativo, que reproduce de forma apodíctica sin mayores argumentaciones adicionales y sin aceptar el reto interpretativo que la reforma le planteaba.

Recuerda al respecto su doctrina por la que la referencia al concepto de legislación estatal comprende la normativa aprobada no sólo en el ejercicio de la potestad legislativa sino también de la potestad reglamentaria. Mientras que el planteamiento del Estatuto era que, en función de las competencias que la Generalitat dispone en cada materia, la potestad reglamentaria que despliegue la legislación del Estado no había de ser ejercida exclusivamente por el propio Gobierno central sino también, en su caso, la ejercida por el Gobierno de la Generalitat. Pero, el Tribunal niega la constitucionalidad de esta previsión estatutaria interpretando que: «si la competencia ejecutiva de la Generalitat puede ejercerse, a partir de la «normativa (legal y reglamentaria) del Estado, no sólo como función ejecutiva strictu sensu, sino también como potestad reglamentaría de alcance general» (FJ 61), la respuesta ha de ser negativa. Y acto seguido, apoyándose en la mencionada STC 51/2006, añade que la potestad reglamentaria de la Generalitat solamente puede tener cabida en la Constitución si se entiende «limitada a la emanación de reglamentos de organización interna y de ordenación funcional de la competencia ejecutiva autonómica» (FJ 61). Pues de esta forma interpreta- que no perjudica la constitucionalidad del artículo 112 del Estatuto. En consecuencia, queda imposibilitada la concurrencia de la potestad reglamentaria con efectos ad extra entre el Estado y la Generalitat.

Sobre este apartado referido a la tipología de las competencias (Cap. I Título IV), cabe concluir que es el más decisivo de la sentencia. La declaración de inconstitucionalidad y nulidad declaradas sobre una parte el artículo 111 (competencias compartidas) y el sentido tan restrictivo atribuido por las dos interpretaciones de los artículos 110 (competencias exclusivas) y 112 (competencias ejecutivas), analizadas conjuntamente, suponen la desnaturalización del sistema concreción funcional y material de las competencias que el Estatuto de 2006 había configurado, con el fin de garantizarlas ante la reiterada capacidad de penetración mostrada por el legislador estatal. En este sentido no puede haber temor a que el Tribunal haya modificado su doctrina sobre el Estado de las autonomías, sino que más bien ha optado por la interpretación más restrictiva en lo que concierne a las competencias. Sus efectos son demoledores ${ }^{46}$.

46 Una parte de estos argumentos, a los que aquí se añaden otros, los he expresado en: «Después de la sentencia, un Estatuto desactivado», Op. cit. pp. 28-30 


\section{JaVier Corcuera AtienZA}

La reflexión constitucional que culmina en el texto del Estatuto venía afirmando la ausencia de un modelo constitucional autonómico (o su permanente apertura), la efectividad del principio dispositivo y la capacidad del Estatuto de Autonomía, elemento del «bloque de constitucionalidad» para afectar a la interpretación de las categorías constitucionales en materia autonómica

Invocar el principio dispositivo después de que las reformas de los noventa culminaran la asunción de competencias en el marco del artículo 149 CE suponía entender que no hay modelo, y que lo que fue instrumento para la puesta en marcha del sistema seguía siendo útil para su indefinida redefinición. Implica, como dice López Basaguren, que la desconstitucionalización del modelo territorial y el principio dispositivo no eran el resultado de la necesidad impuesta por las circunstancias históricas de los primeros momentos sino que se convertían en una virtud del sistema, que permitía abordar la resolución de las nuevas necesidades catalanas.

Más o menos flexible, el modelo es en buena medida el resultado de la actividad del Tribunal Constitucional, que ha ido definiendo las categorías y buena parte de los contenidos de lo que Aragón Reyes llamó, por eso, «Estado jurisprudencial autonómico». Ello había permitido definir unos límites y unas reglas de juego que ahora se trataba de reinterpretar. Entre ellas está la noción de «bloque de constitucionalidad», según el cual los conflictos planteados en el orden territorial autonómico han de resolverse desde la Constitución, pero, en no pocas ocasiones, han de tenerse en cuenta otros parámetros: desde luego, los Estatutos y, también, las leyes (particularmente las orgánicas) a que llamara la Constitución en el ámbito autonómico. La interpretación que daban al tal bloque los impulsores del Estatut subrayaba la particular importancia de los Estatutos en el bloque de constitucionalidad: las reformas estatutarias tienen que incidir en las categorías definidas por el Tribunal Constitucional anteriormente, incluso cuando la interpretación que éste realizó no derivara del anterior Estatuto sino de la Constitución. Si ello es así, el Estatuto puede intentar delimitar las competencias del Estado mediante su definición de las competencias autonómicas. A esto se orienta el llamado «blindaje competencial», doble mecanismo que pretende definir el alcance de las respectivas atribuciones del Estado y de la Comunidad particularmente en las materias compartidas.

Por una parte, se definen las categorías, alterando el sentido que les venía dando la jurisprudencia constitucional. Ello es particularmente chocante cuando el artículo 111 del Estatut reduce el alcance de la normativa básica del Estado, a «principios o mínimo común normativo en normas con rango de ley, excepto en los supuestos que se determinen de acuerdo con la Constitución y el presente Estatuto». El segundo mecanismo es la delimitación como exclusivas de múltiples concretas atribuciones en materias compartidas, con lo que se pretende que tales aspectos no pudieran en ningún caso incluirse entre las cuestiones que el Estado considerara básicas y, en consecuencia, sometidas a limitaciones derivadas de su legislación de aquel carácter.

Pero tal definición de lo básico ignoraba la Constitución, que deja en manos del Estado tal tarea. Por otra parte, dicho procedimiento pretende consagrar en una ley, aunque sea tan particular como un Estatuto de Autonomía, una determinada interpretación de la Constitución, cerrando cualquier otra. Actuando así, el Estatut reproducía la técnica de la 
LOAPA o, como señaló Luis Ortega, actuaba como una especie de LOAPA invertida, que pretende imponer una determinada interpretación de los preceptos constitucionales relativos a las competencias exclusivas, compartidas y ejecutivas, cerrando cualquier posibilidad de intervención al legislador, ordinario u orgánico. Finalmente, no parece razonable utilizar una técnica que permite definir en el Estatuto de una Comunidad un elenco de aspectos que no pueden ser considerados básicos por el Estado, de modo que tal relación puede ser diferente en cada Comunidad (y que de hecho lo era entre los estatutos andaluz y catalán).

La sentencia cierra el debate: existe modelo constitucional autonómico, y se plasma en el texto constitucional y en la lectura que el Tribunal Constitucional ha realizado del mismo. Un Estatuto de Autonomía no puede definir las categorías ni puede reducir las competencias que la Constitución atribuye al Estado. Es posible que la sentencia no cierre el debate, pero sí lo coloca en otro lugar: si se quiere modificar el sistema, habrá que cambiar la Constitución. Lamentablemente, es previsible que tenga que transcurrir algún tiempo hasta que los ánimos estén lo suficientemente serenos como para conseguir una reforma constitucional que, al menos, tenga los apoyos que tuvo el texto vigente. Pero va siendo hora de abordar la tarea.

\section{JAVIER GARCÍA RoCA}

Esta parte de la sentencia, la más larga (FF.JJ. $56^{\circ}$ a $109^{\circ}$ ), es técnicamente muy correcta, está bien escrita y no albergo básicamente reparos ${ }^{47}$. Las competencias del Estado y de las Comunidades Autónomas son un objeto de naturaleza multilateral y deben ser reguladas por el titular de la competencia de competencias. Un pronunciamiento central es que el Estado no puede ser competente de distintas maneras aunque tenga competencias relativamente diferentes en cada Comunidad en función de las asunciones estatutarias. Ahora bien, bastantes de las preocupaciones que llevaron a la elaboración del Estatuto, derivadas de la inseguridad jurídica y las deficiencias de nuestras reglas competenciales, muy necesitadas de ajustes y clarificaciones, eran correctas y deberían ser retomadas por una reforma de la Constitución debidamente consensuada.

1. Es interesante la comprensión del principio de bilateralidad (artículo 3.1 EAC) en las relaciones de la Generalidad con el Estado. Un buen correctivo centrípeto a las tendencias centrífugas de nuestro Estado autonómico. El Tribunal Constitucional desestima (F.J. $13^{\circ}$ ) la inconstitucionalidad del artículo mediante una interpretación constitucional de rechazo, repleta de matices que desactivan cualquier interpretación confederal o bilateralista en exceso. Se acepta que el Estatuto no es sede normativa inadecuada para la proclamación de los principios que deben inspirar las relaciones entre la Generalidad y el Estado. Pero seguidamente se afirma que una bilateralidad estricta sería imposible pues «la parte sólo puede relacionarse con el todo en términos de integración y no de alteridad». Además el Estado central o general mantiene una relación con la Generalidad que

47 En buena parte sintetizo y comento materiales de la crónica sobre «Justicia constitucional: procesos y competencias» preparada para Justicia Administrativa, Lex Nova, $\mathrm{n}^{\circ} 50$, preparada por un quincena de profesores que coordino en esta tarea y a la que reenvío in extenso. 
no es de igualdad sino de superioridad y que no excluye la multilateralidad con otras Comunidades Autónomas. La bilateralidad sólo puede proyectarse en un principio general de cooperación implícito en nuestra forma territorial de Estado.

2. Me parece una salida airosa de un peligroso impasse lo que se dice sobre la función descriptiva o sistematizadora de los Estatutos en materia de categorías competenciales, salvaguardando que la definición de categorías no puede tener otra sede que la Constitución formal ni más sentido que el prescrito por la jurisprudencia del intérprete supremo.

La definición de categorías constitucionales (STC 31/2010, F.J. $57^{\circ}$ ) se afirma: «no puede tener otra sede que la Constitución formal ni más sentido que el prescrito por su intérprete supremo (artículo 1.1 LOTC)». Los Estatutos pueden asignar o atribuir competencias a las Comunidades Autónomas. Pero qué haya de entenderse por «competencia» y qué potestades comprenda son presupuestos de la definición misma del sistema en que el ordenamiento consiste y están reservados a la Norma primera que lo constituye. Las competencias del Estado central pueden no ser iguales, finalmente, en cada una de las Comunidades Autónomas según las diferencias en sus Estatutos, pero no pueden coexistir dentro del Estado autonómico diversas maneras de ser competente. El Tribunal Constitucional, en su condición de intérprete supremo de la Constitución, es el único competente para la definición auténtica de las categorías y principios constitucionales. Pero, ante la «indefinición del texto constitucional» y la «dispersión de los criterios constitucionales» presentes en una doctrina emanada a lo largo de tres décadas, existe un «cierto grado de incertidumbre en la identificación formal de las categorías y principios del modelo territorial» como es propio de toda obra jurisprudencial. En esas circunstancias los Estatutos pueden «relacionar sin definir, esto es, sin otro ánimo que el descriptivo de una realidad normativa que les es en si misma indisponible» (F.J. $58^{\circ}$ ). Este es el sentido de las previsiones de los artículos 110 a 112 EAC. Pero, esta sistematización no supone un cambio en su cualidad normativa, siguen siendo principios jurisprudenciales que pueden ser modificados o revisados por el Tribunal Constitucional.

Obsérvese, no obstante, el serio testimonio de pobreza del sistema, que el propio Tribunal Constitucional que en buena medida lo ha creado reconozca la indefinición del modelo y la inseguridad de los criterios y reglas competenciales. Deberíamos leer estas reflexiones como una invitación a la reforma constitucional de las reglas de división de competencias para clarificarlas y ponerlas al día. Cualquier jurista con experiencia sabe lo extremadamente complejo que es desde hace tiempo redactar un proyecto de ley con problemas competenciales y las dificultades que entraña su aprobación parlamentaria. La confusión de nuestro sistema de descentralización suscita serios problemas de gobernabilidad; la reforma que se propugna no es un divertimento académico sino una responsabilidad de Estado.

3. Respecto de las competencias exclusivas (F.J. 59\%), se advierte que, en los listados estatutarios, la exclusividad no siempre es coextensa con una materia ni desde luego impide las competencias del Estado. Esto es muy correcto y aleja el riesgo de apropiaciones indebidas de competencias constitucionales del Estado en el Estatuto. Pero hace preguntarnos de nuevo qué sentido técnico posee continuar enumerando largos elencos de competencias exclusivas que inducen a confusión a los propios gestores políticos de las competencias y que no se corresponden frecuentemente con la realidad de su régimen jurídico. ¿Cuándo cambiaremos esa deriva aclarando el deslinde en la Constitución con unos listados competenciales más precisos? 
El Tribunal concluye, con una interpretación conforme que lleva al fallo, según la cual el artículo 110 EAC no es contrario a la Constitución en tanto se aplique a supuestos de competencia plena de la Comunidad Autónoma y no impida las competencias exclusivas del Estado cuando concurran en un espacio físico u objeto jurídico, o se trate realmente de competencias compartidas, que no requieren de salvaguarda explícita en el Estatuto.

Desde esta lógica, se hacen muchas afirmaciones que deben reservarse. Veamos algunas. La competencia del Estado para dictar las condiciones básicas que garanticen la igualdad en el ejercicio de derechos fundamentales (art. 149.1.1 ${ }^{\mathrm{a}} \mathrm{CE}$ ) se proyecta sobre la competencia autonómica en materia de asociaciones y fundaciones (F.J. $66^{\circ}$ ). De igual forma, la competencia exclusiva de la Generalitat en materia de comercio interior no coarta el ejercicio de las competencias del Estado en materia de legislación civil y mercantil (art. 149.1, apartados 6 y 8 CE). También se señala expresamente que la competencia autonómica sobre regulación de los horarios comerciales debe cohonestarse con la competencia que al Estado atribuye el art. 149.1.13 CE sobre ordenación general de la economía (F.J. $68^{\circ}$ ).

Otros ámbitos que aparecen calificados en el Estatuto como de competencia exclusiva de la Generalitat y en los que el TC declara que existe algún tipo de concurrencia de títulos estatales y autonómicos son: defensa de los consumidores (F.J. $70^{\circ}$ ), corporaciones de derecho público y profesiones tituladas (F.J. $71^{\circ}$ ), cultura (F.J. $73^{\circ}$ ), denominaciones e indicaciones geográficas y de calidad (F.J. $75^{\circ}$ ), educación (F.J. $77^{\circ}$ ), publicidad (F.J. 98 $)$, régimen local (F.J. $100^{\circ}$ ), sanidad, salud pública, ordenación farmacéutica y productos farmacéuticos (F.J. $102^{\circ}$ ) y servicios sociales, voluntariado, menores y promoción de las familias (F.J. $104^{\circ}$ ).

En otros casos, como sucede en materia de protección civil, se afirma que el propio Estatuto reconoce la situación de concurrencia de competencias, y se subraya que la asunción autonómica de competencias está subordinada a las superiores exigencias del interés nacional, según había ya interpretado la jurisprudencia constitucional previa (F.J. $78^{\circ}$ ).

4. Con las competencias compartidas se resuelve (F.J. $60^{\circ}$ ) que el Estatuto no es sede para dilucidar si las bases son principios o un mínimo común normativo y si deben formalizarse en leyes. Es una decisión acertada, pues no puede un Estatuto imponer un entendimiento de las bases a otros Estatutos, al estar consolidada la jurisprudencia constitucional según la cual un Estatuto no puede ser fuente de la validez de otro.

Así el TC declara la nulidad del inciso del art. 111 EAC que definía la legislación básica del Estado como «principios o mínimo común normativo en normas con rango de ley», pues el precepto no se atenía al concepto constitucional de bases estatales definido por la jurisprudencia. El alcance de las bases difiere en función del subsector de la materia sobre la que se proyectan, y, si bien se reconoce que la definición de las bases como mínimo común normativo es la que mejor se acomoda a su función estructural y homogeneizadora, si las bases son principios o normas mínimas no es asunto a dilucidar en un Estatuto sino sólo en la Constitución, porque su alcance no puede ser distinto en cada Comunidad Autónoma. Respecto del concepto formal de bases, el Tribunal recuerda que la jurisprudencia ha admitido la posibilidad de atribuir carácter básico a normas reglamentarias y actos de ejecución del Estado, aunque la forma de ley sea el vehículo más adecuado para garantizar la estabilidad y certeza de las bases. 
5 Con las competencias ejecutivas de las Comunidades Autónomas, se reitera que incluyen sólo los reglamentos de organización interna y de ordenación funcional, frenando el intento estatutario de ampliarlas a toda la potestad reglamentaria.

El Tribunal, mediante una interpretación correctora que se lleva al fallo, limita el alcance de la potestad reglamentaria a que se refiere ambiguamente el art. $112 \mathrm{EAC}$ a la emanación de «reglamentos de organización interna y de ordenación funcional de la competencia ejecutiva autonómica»; dos cosas que no parece puedan diferenciarse en la práctica. La Sentencia descarta que la competencia ejecutiva de la Generalitat incluya una potestad reglamentaria de alcance general (F.J. $61^{\circ}$ ) como se pretendía al principio. Queda pues alejada toda duda de que la disposición estatutaria pueda abrogar una línea de jurisprudencia muy consolidada que atribuye al Estado, desde principios de los años ochenta, la potestad reglamentaria de desarrollo externo o ejecución de la legislación estatal y tiene un fundamento constitucional más amplio que el de las previsiones de los Estatutos.

6. Es relevante lo que se reitera sobre el principio de territorialidad y la posible eficacia extraterritorial de algunas competencias, pero, sobre todo, se aclara que la determinación de los puntos de conexión de las competencias debe realizarse en el Estatuto y en «otras disposiciones legales», al parecer, del Estado, pero no de las Comunidades Autónomas.

Se desestima (F.J. 63) la impugnación del art. 115 EAC, que menciona la eficacia extraterritorial de las competencias en ciertos casos, por considerar que el recurso se basa en una interpretación contingente e hipotética del precepto, «incompatible con nuestro modelo de justicia constitucional». Se afirma que el precepto es irreprochable, pues refiere normalmente al territorio de Cataluña el ámbito material de las competencias. Los recurrentes realmente discutían que esa eficacia extraterritorial pudiera fijarse en una ley autonómica, aceptando que, en cambio, pudiera hacerse en el propio Estatuto. Se elude aparentemente realizar un juicio preventivo de constitucionalidad, puesto que se dice que esa interpretación no es la única ni necesaria, porque el precepto puede ser interpretado en el sentido de que las disposiciones legales invocadas sean estatales.

De manera que acaba por sentarse — si no entiendo mal esta finta argumental— que sólo las leyes estatales pueden fijar puntos de conexión de las competencias autonómicas además de los Estatutos. Lo cual parece lógico, desde la perspectiva sistemática de las reglas de distribución de competencias, puesto que no es un objeto que se preste a un tratamiento bilateral en vez de a una ordenación multilateral.

7. Con las largas listas de materias competenciales, se reconoce la validez de su descripción detallada en el Estatuto, siempre y cuando se desprenda de la Constitución conforme ha sido interpretada por el Tribunal Constitucional. Pero eso si las normas básicas estatales pueden configurar libremente las materias y submaterias desde el respeto a la Constitución. Se advierte que no son necesarias las cláusulas estatutarias de salvaguardia de las competencias del Estado que emanan directamente de la Constitución.

La descripción detallada de submaterias es otro de los rasgos característicos del Estatuto de Cataluña, la sentencia mantiene su constitucionalidad, pero le priva de buena parte de su eficacia ordenadora. Así se considera que esta técnica descriptiva no es inconstitucional siempre que se respete en la realidad el límite de las competencias reservadas al Estado por la Constitución e interpretadas por el Tribunal Constitucional en necesaria 
correspondencia con la interpretación efectuada de los artículos 110 a 112 EAC; «sin necesidad de que el Estatuto incluya cláusulas de salvaguardia de las competencias estatales» (F.J. 64\%).

De acuerdo con la caracterización ya expuesta de las competencias exclusivas, compartidas y ejecutivas, el Tribunal Constitucional va revisando los extensos y concretos preceptos competenciales, siguiendo sendas pautas y limitaciones. Primero, «sin abundar en los detalles y pormenores» de un modelo que «requiere del concurso de una normativa de aplicación y desarrollo aún inexistente», lo que le lleva a menudo a rechazar resolver conflictos meramente virtuales, hipotéticos y preventivos. Segundo, dentro de los límites atribuidos a las categorías y conceptos constitucionales en los últimos treinta años de jurisprudencia constitucional.

Uno de los interrogantes deriva del reconocimiento de que las leyes básicas, cuando disciplinen una regulación sustantiva, pueden configurar con plena libertad las materias y submaterias, desplazando a las previsiones estatutarias. La solución parece adecuada, pues las materias competenciales que la Constitución enuncia no pueden ser un puzzle, un rompecabezas con diferente contenido en cada Comunidad Autónoma aunque puedan variar en el sí y en el quantum. Ahora bien, me pregunto si las previsiones estatutarias de submaterias no operarán en adelante al menos como una invitación al legislador estatal a dar por bueno ese reparto. Es probable que, de hecho o de Derecho, acabe siendo así, pero el legislador pudiera libremente no sentirse condicionado en ciertos casos. En resumen, la apertura de las materias competenciales en los Estatutos al legislador estatal que delimite las competencias, e incluso el legislador básico, parece cierta, y el efecto del pretendido blindaje resulta desactivado.

\section{Luciano Parejo Alonso}

La incursión estatutaria en la taxonomía de las competencias que precede a las operaciones de asunción de éstas en las diferentes materias coloca al Tribunal Constitucional ante la tarea de la aplicación al Estatuto de su doctrina sobre las normas meramente interpretativas de la Constitución. El comienzo de su discurso es enteramente congruente con ella: la formalización estatutaria de uno de los varios sentidos que puedan tener las categorías constitucionales determinantes del concepto, contenido y alcance de las funciones legislativa y ejecutiva (incluso, dentro de ella, la administrativa) infringe un claro límite cualitativo. Ni siquiera su acomodación a las soluciones jurisprudenciales establecidas puede resolver tal infracción, en tanto que equivalente - aquélla- a una verdadera apropiación de la función exclusiva del Tribunal Constitucional que, además, olvida que a ésta es inherente la posibilidad del cambio de criterio.

Pero el ulterior desarrollo de la argumentación reserva la sorpresa de la afirmación de que, a pesar de la operación tipológica que lleva a cabo, el contenido de los artículos 110, 111 y 112 del Estatuto no disciplina cuestión alguna que sea ajena a la disponibilidad cuando justamente definen lo que sean las potestades legislativa, reglamentaria y ejecutiva comprendidas en las competencias asumidas. La sorpresa se propina abruptamente, sin preparación previa y sin otra explicación posterior que la reflexión desplegada en los siguientes tres pasos: 
a) La indefinición (¡sic!) de la norma constitucional y los términos ${ }^{48}$ propios de la decantación de la jurisprudencia constitucional durante tres décadas han conducido a un cierto grado de incertidumbre en la identificación formal de las categorías y los principios del modelo territorial del Estado, una vez configurados éstos por la jurisprudencial constitucional.

b) La expresión formal del resultado del proceso de decantación del expresado cuerpo de doctrina, es decir, de la definición jurisdiccional acabada del contenido sustantivo de dicho resultado, con reducción del mismo a unidad mediante la ordenación en sistema, adolece, por tanto, de las carencias características de toda obra jurisprudencial en términos de cognoscibilidad y reconocimiento.

c) Por lo que, en definitiva, la relación ordenada y sistemática — con finalidad expositiva y de acuerdo con la jurisprudencia constitucional - del conjunto de potestades, facultades y funciones que integran el contenido funcional de las competencias asumidas está en la disposición del legislador estatutario. Nótese que el énfasis se pone, de propósito para llegar a esta conclusión, en el supuesto mero carácter descriptivo de las disposiciones estatutarias de una realidad normativa que, ésta sí, es ya, en si misma, indisponible.

La sorpresa viene no solo de lo abrupto del giro, sino del esfuerzo al límite a que se somete la tarea interpretativa no ya para ampliar la función y, por tanto, el contenido de la norma estatutaria más allá de lo institucional, sino ahoya ya, incluso y también, para extender su disposición operando en el campo institucional que le es constitucionalmente propio. Las claves aquí son:

- La conversión, por la sola virtud de la palabra interpretativa del Tribunal Constitucional, de prescripciones cuyo tenor literal parece hacerles sospechosas, conforme al propio razonamiento inicial de aquél, de formalización de una mera interpretación de categorías constitucionales, operación prohibida por la norma fundamental, en previsiones que se agotan en la mera relación, describiéndolos, de conceptos ya establecidos. Relación que, a pesar de ello, puede no agotarse, como, en efecto, no se agota, en la mera operación que enuncia, sino que — sin incurrir, por ello, en desliz interpretativo alguno- expresa un orden y sistema, obviamente debido al legislador estatutario. Y ello a pesar de que lo descrito — los conceptos determinados por la jurisprudencia constitucional— padece las carencias a que antes se hizo mención.

- La conversión aludida, con consiguiente rebaja de la textura y el alcance del contenido prescriptivo de las normas estatutarias examinadas, permite descartar el efecto de transgresión del límite cualitativo constitucional pertinente gracias a la simultánea afirmación de la definición constitucional de los correspondientes conceptos objeto de mera descripción en sede de la jurisprudencia constitucional, calificada, sin mayor discriminación, como «realidad normativa». El hecho de que esta realidad pueda cambiar por efecto de la evolución de la jurisprudencia es circunstancia que no importa a los efectos del discurso, pues lo mismo puede suceder, en hipótesis, con la Constitución misma, en tanto que susceptible de reforma y revisión.

48 Que comportan inevitablemente la dispersión en el cuerpo de la doctrina sentada de los criterios constitucionales determinantes. 
Ocurre que este trabajoso discurso presenta sombras de difícil disipación y, en particular, las siguientes:

$1^{a}$. Medida por la realidad normativa presente, la interpretación conforme expuesta aparece bajo la luz de un constructo ad hoc que lejos de aplicar aquélla la innova, suscitando por el momento dudas de asimetría injustificada en la construcción del bloque de la constitucionalidad en materia competencial (salvo que se consolide y generalice, sustituyendo la doctrina actual). Pues, aquí y ahora, supone que el legislador estatutario puede hacer desde luego lo que al legislador estatal básico, bastante más discreto en sus pretensiones que aquél, se le ha negado con toda contundencia y sin mayor matización hasta el momento.

$2^{a}$. La rebaja del contenido prescriptivo de las previsiones estatutarias por el solo efecto del aditivo interpretativo añadido, sin mayor fundamento y en virtud de su autoridad, por el Tribunal Constitucional vuelve a situar a éste al borde mismo de los límites de su función constitucional. No puede caber duda alguna, en efecto, que el aditivo jurisprudencial cambia objetivamente el referido contenido, único establecido por el verdadero legislador.

$3^{a}$. El otorgamiento alzado a la jurisprudencia constitucional de la condición de realidad normativa oculta que no toda la realidad así aludida en bloque tiene, sin embargo, sustancia normativa, en tanto que buena parte de la clarificación doctrinal de los conceptos constitucionales aludidos se ha producido no en los fallos de los pronunciamientos del Tribunal Constitucional, sino en la fundamentación de éstos y tanto a título de ratio decidendi, como de obiter dictum. Con las consecuencias que de ello se siguen y en las que aquí no parece preciso abundar.

No puede sorprender, pues, que, ni siquiera desde las premisas sentadas por el Tribunal Constitucional, pueda el contenido concreto de los artículos 110, 111 y 112 del Estatuto salir plenamente airoso del examen de su constitucionalidad, ni desde luego logre quedar del todo indemne a resultas de éste.

El primero de ellos únicamente lo supera mediante una nueva vuelta de tuerca interpretativa, escasamente fundamentada y aumentadora del riesgo de desbordamiento de la función jurisdiccional, sobre el significado del carácter preferente de la aplicación del Derecho catalán en las materias de la competencia exclusiva de la Generalitat. Esta importante cuestión del sistema de concurrencia en el espacio de normas de distinta procedencia en modo alguno puede despacharse con la simple referencia a lo ya dicho, es decir, implícitamente al supuesto y en verdad inexistente carácter meramente descriptivo de la regla estatutaria, y el no impedimento por ésta de la aplicación del Derecho estatal emanado del ejercicio de competencias concurrentes con las autonómicas. Lo primero porque, al cualificar la regla el Derecho catalán como tal a efecto de la elección del aplicable, en caso de concurrencia con el estatal, en primer lugar o con preferencia, no puede decirse que sea meramente descriptivo (lo desmiente ya, a pesar de lo que diga la Sentencia, la expresión estatutaria «en todo caso»). Y lo segundo, porque la permanencia (faltaba más) de las reglas constitucionales de la prevalencia y la supletoriedad del Derecho estatal nada dice, por si sola, de la regularidad constitucionalidad de la estatutaria considerada.

La correcta declaración de inconstitucionalidad del inciso del artículo 111 del Estatuto relativo a la fijación por el Estado de las bases como principios o mínimo común 
normativo en normas con rango de Ley, excepto en los supuestos que se determinen de acuerdo con la Constitución y el Estatuto representa todo un desmentido objetivo al esfuerzo de interpretación conforme desplegado por el Tribunal Constitucional. Si el concepto constitucional de bases estatales (definido jurisprudencialmente) resulta distorsionado por el Estatuto y, más aún, si lo que sean las bases no es, literalmente, «asunto a dilucidar en un Estatuto, sino sólo en la Constitución, vale decir: en la doctrina de este Tribunal Constitucional», ¿cómo entonces puede suponerse con carácter general que la operación de ordenación y sistematización que de la jurisprudencia hace éste tiene mero alcance descriptivo de la realidad normativa? Y si entre los argumentos que se aducen para excluir lo que sean las bases del contenido de los Estatutos se incluye el carácter mudable de dichas bases y el carácter rígido del procedimiento de aprobación de éstos, ¿por qué tales argumentos, aplicados al carácter evolutivo y, por tanto, mudable de la realidad normativa generada por la jurisprudencia constitucional no valen para excluir la taxonomía estatutaria de las competencias? Pues, en la medida en que la admisión de ésta implica la de la potencial diversidad de la clasificación de las competencias (indirectamente o por reflejo también las del poder central), no puede olvidarse la cuestión subyacente: ¿es compatible con el modelo territorial y, en particular, las características que el propio Tribunal Constitucional predica del poder-ordenamiento general, la aludida diversidad potencial?

Del rigor técnico empleado en el examen del artículo 111 se vuelve, en el del artículo 112 también del Estatuto, al esfuerzo interpretativo llevado al límite. Al reproche de la atribución inequívoca a la Comunidad Autónoma, en el ámbito de sus competencias ejecutivas, de la potestad reglamentaria y la ejecutiva en sentido estricto (comprensiva, a su vez, de la de organización), el Tribunal Constitucional, lejos de fundamentar su desestimación, le opone, sin especificar su aplicabilidad al caso y su virtualidad enervante del reproche, su doctrina constitucional relativa a: i) la inclusión en la competencia legislativa estatal de la potestad reglamentaria; ii) la exclusión de la competencia ejecutiva autonómica de la potestad reglamentaria ad extra, aunque sí de la potestad reglamentaria ad intra. Tan es así, que ni siquiera detecta la incorrección de la formalización estatutaria de la potestad de organización como exclusivamente residenciada en la ejecución en sentido estricto, siendo así que dicha potestad es inherente a toda organizaciónfunción estatal lato sensu y está distribuida entre las constituidas con independencia de si la función ejercida es la legislativa o la ejecutiva; formalización, que habría justificado desde luego la declaración de su inconstitucionalidad.

El análisis pormenorizado de las consideraciones desarrolladas en la Sentencia a propósito de los concretos preceptos atributivos de competencias desborda sin duda el propósito de estas líneas. Puede decirse, sin embargo, que, limitado el margen discursivo por su propio planteamiento, el Tribunal Constitucional opera en general de modo consecuente. Pues en la valoración no cabe prescindir de la específica dificultad del deslinde territorial de las competencias en nuestro sistema constitucional, tanto más si se le suma el criterio observado hasta hora en este terreno para la resolución de los frecuentes conflictos que suscita.

El examen de la regulación estatutaria de las materias de la competencia autonómica se abre, en efecto, con el recordatorio de lo ya dicho: que los preceptos correspondientes sólo llevan a cabo una «descripción» detallada y sistematizadora de submaterias; recor- 
datorio, que se considera suficiente para afirmar que nada se opone en el artículo 147.2, d) CE a que un Estatuto la efectúe, «siempre, obviamente, en el marco de la Constitución y respetando el límite de las competencias reservadas al Estado ex art. 149.1 CE». El parámetro de enjuiciamiento de la corrección del cumplimiento por el Estatuto de su cometido, permanece, pues, invariable: el respeto de los límites derivados de la doctrina constitucional definitoria de los conceptos y las categorías constitucionales sobre los que se desarrolla el régimen de la distribución territorial de las competencias.

Ocurre que la doctrina constitucional así invocada, puede sin duda justificarse como necesaria y positiva desde el punto de vista del proceso constructivo del Estado autonómico, y hoy, incluso, cabe afirmar su bondad en su formulación en abstracto: lo dispuesto en la Constitución no puede ser menoscabado por lo que establezca un Estatuto (establezca éste lo que establezca); no hace falta que un Estatuto incluya, en las fórmulas de asunción de competencias, cláusulas algunas de salvaguardia de las competencias estatales stricto sensu; con entera independencia de lo que diga un Estatuto sobre las competencias autonómicas, el poder central siempre podrá ejercer las suyas, ex constitutione, con total libertad; y, por tanto, cuando en preceptos estatutarios existan previsiones contradictorias con dichas competencias, tales previsiones han de tenerse por efectuadas impropiamente y sin capacidad alguna de producir efectos que cercenen o menoscaben las estatales, su libre despliegue y su proyección sobre las autonómicas. Pero el problema no radica en tales afirmaciones generales, sino en la determinación concreta del deslinde competencial en cada una de las materias y submaterias (conforme a la tipología previamente admitida) y en si, por tanto, el Estatuto es la sede idónea justamente de la concreción detallada y en tales términos de dicho deslinde (y no ya sólo, aunque también, por razón de la dificultad, ya expresada, de reconocer a la entera «realidad normativa» que sirve de parámetro de enjuiciamiento justamente «sustancia normativa ${ }^{49}$ ).

La función del Tribunal Constitucional, desde luego al día de hoy (transcurridos más de treinta años de «constituido» el Estado autonómico), no puede seguir siendo viabilizar - gracias a una jurisprudencia flexible - el proceso constructivo de la dimensión territorial del Estado; ha de ser ya la de garantizar la corrección e idoneidad constitucionales de la organización y el funcionamiento de dicho Estado, procurando la clarificación del deslinde competencial mediante la depuración de las normas correspondientes. El cumplimiento de este cometido es especialmente importante cuando se trata de las normas que completan el bloque formado por los artículos 148.1/149.1 CE y los Estatutos de Autonomía. Pues de la claridad del deslinde que de tal bloque resulte depende que no opere como semillero de conflictos con ocasión del concurso ${ }^{50}$, bien advertidamente como necesario, de múltiples ulteriores normas. A lo que no contribuye el retranqueo voluntario del Tribunal Constitucional al parámetro utilizado para posibilitar

49 Los fundamentos jurídicos de las Sentencias del Tribunal Constitucional, incluso los constitutivos de la ratio decidendi, tienen solo el valor propio de la jurisprudencia en tanto no tengan reflejo en los respectivos fallos. Y estos últimos, en realidad, únicamente tienen «efecto», que no «sustancia», normativa, en la medida en que la declaración de inconstitucionalidad «elimina» del ordenamiento al privar a la norma correspondiente de validez. Sólo impropiamente, pues y por emplear el término utilizado por el Tribunal Constitucional, puede atribuirse en bloque sustancia normativa a la «realidad normativa» invocada.

50 Por mayor que pueda ser, como también advierte el Tribunal Constitucional, el grado de definición que, en su letra, alcance el Estatuto de Autonomía. 
el margen preciso para tensionar al máximo la interpretación de las normas estatutarias, con introducción, al efecto, de la nueva e inespecífica categoría de las expresiones y los términos «impropios».

Dicho lo cual, parece que habría sido por lo menos útil plantearse la procedencia de la admisión de previsiones estatutarias «impropias» al menos desde un doble punto de vista: primero, el de la idoneidad o no del Estatuto para incorporarlas y, en su caso, hasta qué punto (aquél en que de impropias se tornan en inconstitucionales) en el contexto del sistema constitucional articulado sobre la base del principio de sucesiva concreción, por razón justamente de la diversidad de las materias y sus, por tanto, diferentes requerimientos (por demás evolutivos) al plano competencial; y luego, el de si no comporta una innecesaria y, en todo caso, indebida petrificación de un deslinde competencial efectuado abstracción hecha de las características de las distintas materias, toda vez que el concurso obligado de ulteriores normas implica la posibilidad (querida por la norma fundamental) de una evolución diferenciada de dicho deslinde y no sólo ineluctablemente en sentido ampliatorio del espacio competencial autonómico ${ }^{51}$.

Las interpretaciones conformes de las concretas atribuciones competenciales posibilitadas por el parámetro utilizado prueban que el resultado conseguido validándolas no puede considerarse satisfactorio al menos desde los criterios expuestos. Así al menos por lo que hace a los dos siguientes extremos:

— La determinación misma de la competencia autonómica.

La admisión de su «impropia» asunción bien como exclusiva sobre la entera materia, bien sin referencia a límite alguno o «en los términos de la legislación estatal», remite simplemente la cuestión de su precisión a ulteriores decisiones de las instancias del deslinde de cuyas esferas competenciales se trata. Los interrogantes que suscita la exclusividad, incluso si se acompaña de la fijación de su contenido material ${ }^{52}$, se despejan, en efecto, con la simple afirmación de que no enerva la atribución competencial que a favor del Estado disponga la Constitución, ni siquiera cuando la enumeración de contenidos

51 A este problema alude la Sentencia en sus fundamentos 58 y 77 , con el insatisfactorio argumento de que las funciones comprendidas en las competencias de las que puede ser titular la Comunidad Autónoma de Cataluña .... serán siempre y sólo las que se deriven de la interpretación de la Constitución reservada a este Tribunal y, de no mediar la oportuna reforma constitucional, su contenido y alcance no será sino el que eventualmente resulte de la propia evolución de nuestra jurisprudencia».

52 Sobre todo cuando i) no se acompaña de salvedad o límite algunos, cual sucede, por ejemplo, con la referida a la materia fundaciones; ii) se precisa mediante expresiones abiertas e indeterminadas — como la «cualquier otro instrumento de consulta popular»— en materias delicadas como la de la consulta popular (por referencia a la del referéndum); iii) se acota mediante una redacción que, obviando la utilizada por la Constitución (normas de Derecho foral o especial), altera formalmente la economía de la distribución competencial prefigurada por ésta: «Derecho civil, con la excepción de las materias que el artículo 149.1.8 de la Constitución atribuye en todo caso al Estado»; o iv) se aprovecha la redacción literal de la atribución competencial al Estado en la Constitución — no de la meteorología sino del «servicio meteorológico» (lo que se entiende perfectamente el contexto del apdo. 20 del art. 149.1 CE desmiente que suponga una materia distinta a las demás enumeradas en el precepto) — para degradar la atribución misma (referenciándola no a una materia, sino a un «objeto jurídico»), aceptándose ésta desde la consideración de que la competencia estatal no impide que los Estatutos de Autonomía puedan atribuir la correlativa competencia sobre el mismo objeto jurídico, siempre que se restrinja al territorio de la respectiva Comunidad y no limite la plena competencia estatal sobre la meteorología en la totalidad del territorio español (consideración, cuya validez final debe hacerse depender de la demostración de lo que hay de diferencial en la meteorología respecto de las demás materias). 
materiales aparece reforzada por la expresión «en todo caso» (despachada, sin más, con su «reducción» al rango de lo simplemente «descriptivo»), que es la cuestión cuya clarificación debía producirse en sede de la Sentencia. Y el condicionamiento que de la competencia estatal sin duda significa (al menos en punto a la existencia misma de la competencia autonómica atribuida estatutariamente) el empleo de la expresión «en los términos» de la legislación estatal se solventa con la sola alusión a una irreal libertad del estado central en el ejercicio de su potestad legislativa.

La permisión de la asunción de competencias propias en el plano ejecutivo en los términos, bien concretos, que resultan, por ejemplo, de los artículos 147 (en materia de Notariado y registros públicos) y 149.3, b) (gestión de los títulos de ocupación y uso del dominio público marítimo terrestre) del Estatuto, supone cerrar los ojos —a pesar, incluso, de la reconocida necesidad de evitar la asimetría, por territorios, de las competencias estatales - al menoscabo que de éstas aquellos términos suponen. El hecho de que a la garantía de la unidad (en materia de la función notarial y de registros públicos) baste con la función normativa y que, por tanto, la ejecutiva sea susceptible de descentralización, en modo alguno quiere decir que la decisión sobre ésta deba o siquiera pueda producirse en sede estatutaria. Lo que vale especialmente para la gestión de un dominio público natural como el marítimo terrestre, soporte del ecosistema específico resultante del encuentro del mar y la tierra. Tanto más cuanto que, seguidamente, el precepto estatutario atribuye la competencia, en todo caso, de las concesiones de obras fijas en el mar y, para salvar tal atribución, el Tribunal Constitucional razona que es legítima precisamente porque la competencia ejecutiva que tiene por objeto aparece sometida al régimen general del dominio público y a las excepciones que puedan establecerse por motivos medioambientales en las aguas costeras interiores y de transición. Pero lo cierto es que esta sujeción no salva en modo alguno la atribución estatutaria directa de una competencia ejecutiva de la indudable titularidad del Estado.

Lo que en todo caso interesa destacar ahora es que la Sentencia está lejos de propiciar la clarificación, en sede estatutaria, del deslinde competencial, es decir, de impedir que dicha sede mantenga o, incluso, empeore la situación de potencial conflicto con ocasión de la autoafirmación, en su ejercicio, de las competencias en que se haga presente tal potencial.

La admisión, vía interpretación conforme y en este contexto, de diversas fórmulas de participación orgánica o funcional de la Comunidad Autónoma, confirma, no ya sólo la «sustancia competencial» de este tipo de previsiones, sino la potencia distorsionante de las competencias estatales afectadas de la regulación estatutaria de sistema de relaciones institucionales advertida ya al tratar de ésta (y desatendida allí por la Sentencia). Pues lo que no cabe ya es salvar las previsiones de participación efectuadas al hilo de competencias en materias o submaterias específicas mediante su conceptuación como previsiones realizadas «con generalidad ${ }^{53}$. Este argumento resultaría válido solo precisamente para

53 Como se hace, por ejemplo y en el fundamento 65, con la prevista en el artículo 117.4 del Estatuto.

Ejemplos claros de participación cuya previsión dista de preverse «con generalidad» y que, a su vez, desvirtúa la «generalidad» de la regulación del sistema de relaciones institucionales, son: —La orgánica del artículo 140.2 del Estatuto, que claramente penetra en la potestad de organización estatal de sus propias estructuras, que no puede despacharse con la consideración de que se trata de una modalidad de cooperación sin 
la regulación del aludido sistema de relaciones, supuesto que fuera acompañado de la reducción efectiva de sus determinaciones a tal generalidad. No se trata aquí de negar la evidente constitucionalidad de la participación misma, sino sólo de poner en cuestión su precisión o en términos condicionantes de ésta precisamente en los Estatutos de Autonomía.

6. ¿La doctrina y los pronunciamientos de esta Sentencia respecto de los contenidos estatutarios en materia de financiación, qué opinión le merecen en su condición de constitucionalista?

\section{ROBERTO BLANCO VALDÉS}

Como no soy un especialista en materia de financiación autonómica me limitaré, en relación con tal pregunta, a manifestar mi acuerdo con los principales pronunciamientos de la Sentencia en esa esfera, que proceden a rebajar las pretensiones, a todas luces excesivas, del Estatuto cuando opta por regular cuestiones para las que una norma de su naturaleza no tiene competencia, aunque apuntaré también un punto de desacuerdo con el juicio llevado a cabo por el supremo intérprete de la Constitución en un ámbito que me parece muy relevante. Por lo que se refiere a lo primero, el Tribunal declara inconstitucional una parte del apartado $3^{\circ}$ del artículo 206: la que determina que la aportación de la Generalitat a la solidaridad y a la nivelación de los servicios se realizará «siempre y cuando [las Comunidades Autónomas] lleven a cabo un esfuerzo fiscal también similar» (art. 206.3). Tal previsión estatutaria es inconstitucional, y en consecuencia nula, porque, según afirma certeramente el TC, es al Estado a quien corresponde «regular el ejercicio de las competencias financieras de las Comunidades Autónomas y fijar los niveles de su contribución a la nivelación y a la solidaridad»; y porque «la determinación de cual sea el esfuerzo fiscal que hayan de realizar las Comunidades Autónomas es cuestión que sólo corresponde regular al propio Estado, tras las actuaciones correspondientes en el seno del sistema multilateral de cooperación y coordinación constitucionalmente previsto». Además, el TC entiende igualmente con buen criterio, que resulta inconstitucional la previsión de que las competencias de la Generalitat en materia de financiación local «pueden incluir la capacidad legislativa para establecer y regular los tributos propios de los gobiernos locales» (art. 218.2) al tratarse de «una potestad exclusiva y excluyente del Estado que no permite intervención autonómica en la creación y regulación de los tributos propios de las entidades locales». En cuanto a los preceptos sometidos a interpretación, me interesa destacar sobre todo tres declaraciones del TC: que la expresión «servicios de educación, sanidad y otros servicios esenciales» que se contiene en el artículo 206.3 del Estatuto como elemento condicionante de la solidaridad territorial es, según el Tribunal, equivalente a la de «servicios públicos fundamentales» del artículo 158 de la Constitución, «sin que en ningún caso pueda tener eficacia reductora desde el

contornos concretos. - La del artículo 149 del Estatuto, pues no solo es funcional (emisión de informe sobre la localización de las infraestructuras y los equipamientos estatales), teniendo también un evidente alcance organizativo al dotar de contenido competencial a la Comisión Bilateral Generalitat-Estado. 
momento en que corresponde al Estado determinar qué servicios públicos son fundamentales»; que la previsión de que el Estado garantizará que la aplicación de los mecanismos de nivelación no altere en ningún caso la posición de Cataluña en la ordenación de rentas per cápita entre las Comunidades Autónomas antes de la nivelación (art. 206.5), sólo puede ser considerada constitucional entendida en el sentido de que esa garantía sólo operaría «cuando la alteración de la posición de la Comunidad Autónoma de Cataluña se debiera, no a la aplicación general de los mecanismos de nivelación, sino exclusivamente a la aportación que realizase Cataluña como consecuencia de su posible participación en dichos mecanismos»; y, en fin, que las funciones de cooperación de la Comisión Mixta de Asuntos Económicos y Fiscales Estado-Generalitat —respecto de la cual el TC sienta una interpretación constitucional restrictiva, paralela a la ya referida para la Comisión bilateral de asuntos políticos-, «no excluyen ni limitan la capacidad de las instituciones y organismos de carácter multilateral en materia de financiación autonómica, no afectan a la reserva de ley orgánica prevista en el artículo 157.3 de la Constitución, ni sustituyen, impiden o menoscaban el libre y pleno ejercicio por parte del Estado de sus propias competencias». Discrepo, sin embargo, del TC en una materia que, como antes señala, creo presenta gran importancia: el Tribunal somete a interpretación conforme la disposición adicional $3^{\circ}$ del Estatuto, según cuyo párrafo primero «la inversión del Estado en Cataluña en infraestructuras, excluido el Fondo de Compensación Interterritorial, se equiparará a la participación relativa del producto interior bruto de Cataluña con relación al producto interior bruto del Estado para un período de siete años. Dichas inversiones podrán también utilizarse para la liberación de peajes o construcción de autovías alternativas». El párrafo segundo añade, además, que «con esta finalidad se constituirá una comisión, integrada por las administraciones estatales, autonómica y local». Aunque el Tribunal opta por declarar la constitucionalidad de tal disposición, siempre que se interprete «en el sentido de que no vincula al Estado en la definición de su política de inversiones, ni menoscaba la plena libertad de las Cortes Generales para decidir sobre la existencia y cuantía de dichas inversiones», no parece difícil llegar a la conclusión de que estamos de nuevo ante uno de esos múltiples casos en que una norma estatutaria se declara compatible con nuestra ley fundamental por el simple expediente de negar que establezca lo que inequívocamente determina, que es, en realidad, aquello que el TC afirma que no puede disponer. A mi juicio lo exigible hubiera sido, en consecuencia, anular, por inconstitucional, una previsión que no tiene otro objeto, en efecto, que el de menoscabar la plena libertad del Estado para decidir en materia presupuestaria, lo que viene demostrado no sólo por la literalidad del párrafo primero de la adicional, sino por el hecho de que el segundo proceda a la creación de una comisión que debería ser la encargada de concretar políticamente tal menoscabo, de todo punto incompatible con una potestad presupuestaria que corresponde al Estado en plenitud según se deduce sin ningún genero de dudas del artículo 134.1 de la Constitución.

\section{Raúl Canosa Usera}

También en esta materia el Tribunal Constitucional advierte que lo previsto en un Estatuto no condiciona la libertad del legislador estatal para determinar en la LOFCA el 
alcance de la financiación autonómica; con arreglo a este criterio, rebaja la eficacia de varios preceptos mediante una interpretación conforme. Declara, empero, la inconstitucionalidad del artículo 206.3 que exigía a otras CCAA «un esfuerzo fiscal similar» y el inciso del artículo 218 que abría la posibilidad de dotar a Cataluña de la «capacidad legislativa para establecer y regular los tributos propios de los gobiernos locales». No cabe desde un Estatuto condicionar la respuesta fiscal de otras CCAA ni despojar al Estado de un competencia que el TC entiende conferida a este por la Constitución. Ahora bien, todo aquello que, previsto en el Estatuto, se incluyó en la última reforma de la LOFCA efectuada por la Ley Orgánica 3/2009, de 18 de diciembre, y en la Ley 22/2009, de la misma fecha, de Financiación de las CCAA (que concretan el Acuerdo 6/2009, de 15 de julio, del Consejo de Política Fiscal y Financiera) es sancionado por el TC.

Es en este terreno de la financiación donde el TC despliega, en línea con toda su sentencia, una labor creativa porque, si bien preserva la exclusividad del legislador estatal para, mediante la LOFCA, delimitar el sistema de financiación de las CCAA, no declara la inconstitucionalidad de los preceptos estatutarios a costa de rebajar su eficacia a meras sugerencias que sólo si se incorporan a la LOFCA, se aplicarían. Como esta incorporación se ha producido en efecto con las reformas de 2009 citadas, el resultado es una convalidación refleja de la constitucionalidad de la LOFCA, al considerarse legítimo el nuevo entendimiento de la solidaridad sugerido por el Estatuto de Cataluña: que tal solidaridad no perjudique a las Comunidades más prósperas. El problema resulta entonces evidente: si las más prósperas no contribuyen a la mejora de las menos desarrolladas ¿cómo éstas despegarán?

\section{MARC CARrillo LÓPEZ}

El punto de partida de la reforma estatutaria en este decisivo aspecto de la autonomía política era el de atribuir al Estatuto, fruto de su naturaleza de norma paccionada y de valor complementario a la Constitución, la condición de pilar básico para la garantía del sistema de financiación. La STC 31/2010 (FFJJ 130 a 142) rechaza de plano este planteamiento, dado que niega que el Estatuto pueda formar parte y participar como instrumento de la garantía del sistema de financiación.

La sentencia se ha pronunciado en este apartado del recurso con dos declaraciones de inconstitucionalidad sobre algunos incisos del contenido de dos preceptos (arts. 206.3 y 218.2 EAC) y diversas decisiones de carácter interpretativo que afectan a partes de los artículos: 206.5; 210.1 y 2.a), b) y d); las Disposiciones adicionales $3^{\mathrm{a}}$, ap. 1 ; $8^{\mathrm{a}}$, $9^{\mathrm{a}}$ y $10^{\mathrm{a}}$ del EAC, haciendo irrelevante su valor jurídico.

El Tribunal se ha ajustado en este apartado a su doctrina tradicional por la que el sistema básico para la financiación autonómica es el que determina la Ley Orgánica de Financiación de las Comunidades Autónomas (LOFCA), por lo que las previsiones estatutarias en materia de financiación serán válidas siempre que previamente estén contempladas en la citada LOFCA. Y en buena parte es lo que ha ocurrido con la aprobación de la Ley Orgánica 3/2009, de 18 de diciembre, en la medida que incorpora las previsiones del Estatuto. La consecuencia de este previsible planteamiento del Tribunal es que ha de ser la LOFCA y no el Estatuto la garantía del sistema de financiación. Para el Tribunal resul- 
ta menos relevante el hecho de que el Estatuto sea también una ley orgánica singular, que ha sido aprobada por las Cortes Generales en un procedimiento dotado de mayor rigidez que la propia LOFCA.

De acuerdo con la doctrina expuesta, y en relación con los mecanismos de nivelación previstos por el Estatuto (art. 206.3 y 5), el Tribunal niega que en lo que concierne a los recursos financieros de los que disponga la Generalitat y su participación al cumplimiento del principio de solidaridad con las otras CCAA, sea el Estatuto la norma que determine la regla de aplicación consistente en condicionar dicha participación, a que el resto de los entes autonómicos lleven a cabo un esfuerzo fiscal similar (mecanismo de nivelación

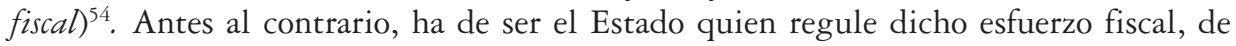
acuerdo con su competencia exclusiva en materia de hacienda general (art. 149.1.14 ${ }^{\mathrm{a}} \mathrm{CE}$ ). Con la supresión de esta referencia al esfuerzo fiscal similar, el mecanismo de nivelación queda desvirtuado porque aquellas CCAA que decidan reducir la carga tributaria sobre sus ciudadanos saben que la pérdida de capacidad financiera la podrán recuperar a través del mecanismo de nivelación ${ }^{55}$.

Otra de las aportaciones del Estatuto era la incorporación del llamado principio de ordinalidad (art. 206.5 EAC) es decir, la garantía de que tras la aplicación de los mecanismos de nivelación fiscal, no se altere la posición de Cataluña en la ordenación de las rentas per capita entre las CCAA existente antes de la citada nivelación. El Tribunal, a través de una decisión interpretativa reconoce (FJ 134) que sería contrario a la solidaridad y al equilibrio territorial que el resultado de la aplicación de los mecanismos de nivelación y de solidaridad diesen como resultado que quien contribuya quede en una posición relativa peor a la que obtenga el beneficiario de la contribución al principio de solidaridad por parte del primero. En este sentido, interpreta que el art. 206.5 EAC solamente es constitucionalmente admisible si se refiere a los recursos que Cataluña aporta a los mecanismos de nivelación, pero excluye las aportaciones que el Estado pueda realizar, lo cual diluye los objetivos que el citado precepto establecía ${ }^{56}$.

La otra declaración de inconstitucionalidad afecta a un inciso del art. 218 que en materia de financiación local incluye, «en el marco establecido por la Constitución y la normativa del Estado» la «capacidad legislativa para establecer y regular los tributos propios de los gobiernos locales». Sin embargo, el Tribunal, siguiendo de nuevo su jurisprudencia anterior (STC 233/1999), excluye cualquier intervención legislativa de carácter tributario local que no sea la del Estado. Cuando de la Constitución (art. 133.2) ${ }^{57}$ no se deriva que la reserva de ley en este ámbito sea únicamente a favor de la ley estatal. Pero el Tribunal nada argumenta acerca de esta posibilidad de concurrencia legislativa que la Constitución no excluye, ni tampoco tiene en cuenta que el Estatuto era especialmente cuidadoso en prever que la capacidad legislativa en materia tributaria local, había de ser

54 Esta previsión también aparece en las reformas estatutarias de Andalucía, Aragón e Islas Baleares.

55 Vid. Bosch, N. y Vilalta, M. «Efectes de la sentència del TC sobre el model de finançament de la Generalitat de Catalunya». Revista Catalana de Dret Públic (Número especial sobre la STC 31/2010). Septiembre 2010 (versión electrónica). (http://www,rcdp.cat).

56 Vi. Sol, P. «El Finançament», Revista Catalana de Dret Públic (Número especial sobre la STC 31/2010). Septiembre 2010 (versión electrónica). (http://www,rcdp.cat).

57 »Las Comunidades autónomas y las Corporaciones Locales podrán establecer y exigir tributos, de acuerdo con la Constitución y las leyes» 
en el marco fijado por la Constitución y la legislación estatal. Es un nuevo supuesto en el que el Tribunal ha rechazado una interpretación conforme a la Constitución que era perfectamente factible.

El carácter interpretativo de la sentencia afecta también a la regulación de los mecanismos de colaboración entre la Generalitat y el Estado (arts. 210.1 y 2.a, b y d): la posición adoptada por el Tribunal es que la relación bilateral siempre habrá de ser de carácter complementario a la que se desarrolla en el seno de los órganos multilaterales. En cuanto a las previsiones estatutarias sobre la regulación de las inversiones del Estado en infraestructuras en Catalunya (Disp. Ad. $3^{a}$ ap. 1), interpreta que no tienen carácter vinculante para el Estado. Y finalmente, en relación a la participación de la Generalitat en tributos estatales (DD. AA. $8^{a}, 9^{a}$ y $10^{a}$ ), se reitera que el Estatuto no es el instrumento adecuado para fijar dicha participación sino que habrá de seguirse el procedimiento correspondiente con «absoluto respeto a la potestad legislativa del Estado que ejercen las Cortes Generales» (FJ 137). De nuevo aquí el Estatuto como norma queda jurídicamente disminuido frente a la LOFCA, a pesar de ser una ley orgánica singular aprobada por las Cortes Generales. Es la ley estatal y no el Estatuto la garantía de la financiación autonómica.

\section{Javier Corcuera Atienza}

Vuelven a manifestarse en esta materia los inconvenientes de querer plasmar en un Estatuto cuestiones que tienen que definirse con carácter general. El Estatut fija principios e instrumentos que hubieran debido regularse en la LOFCA, a la que llama la Constitución, y define órganos de cooperación bilateral que pretenden fortalecer la posición negociadora de la Generalidad ignorando aparentemente la existencia del Consejo de Política Fiscal y Financiera y soslayando el hecho de que la definición de particularidades en el sistema de financiación catalán afecta a todo el sistema de financiación. Ante ello, el Tribunal repite inconcreciones, y la técnica de la interpretación conforme puede permitir prácticas que debiliten la homogeneidad en ámbitos en que es especialmente importante, consagrando un procedimiento que permite definir lo general desde un Estatuto particular.

Por lo que toca a los principios, el tribunal aborda fundamentalmente dos cuestiones: si es constitucional la previsión del artículo 206.3 de que la contribución de la Generalidad a la financiación de la educación, sanidad y demás servicios esenciales de las restantes CCAA esté subordinada a que el esfuerzo fiscal de éstas sea similar al que realiza Cataluña, y si lo es la del párrafo 5 del mismo artículo, que encomienda al Estado garantizar que la aplicación de los mecanismos de nivelación y solidaridad no alteren en ningún caso la posición de Cataluña en la ordenación de rentas per cápita de las Comunidades antes de la nivelación.

En el primer caso, la postura del Tribunal es tajante: se trata de un inciso inconstitucional pues «la determinación de cuál sea el esfuerzo fiscal que hayan de realizar las Comunidades Autónomas es cuestión que sólo corresponde regular al propio Estado, tras las actuaciones correspondientes en el seno del sistema multilateral de cooperación y coordinación constitucionalmente previsto». En el segundo, tal previsión «debería declarar- 
se inconstitucional y nula en el caso de que compartiera esa misma naturaleza condicional e imperativa», pero no se trata de eso, pues es un deber derivado del principio constitucional de solidaridad. De éste se deriva que ha de excluirse «el resultado de la peor condición relativa de quien contribuye respecto de quien se beneficia de una contribución que dejaría entonces de ser solidaria y servir al fin del equilibrio para propiciar, en cambio, un desequilibrio de orden distinto al que se pretende corregir.»

En lo que toca a las instituciones, también abordó el Tribunal la constitucionalidad de la Comisión Mixta de Asuntos Económicos y Fiscales Estado-Comunidad, órgano bilateral de composición paritaria y presidencia rotatoria al que el Estatuto encomienda, sin mencionar a las instituciones multilaterales que siguen existiendo en la materia, la práctica totalidad de los asuntos que interesan a Cataluña en dicho ámbito. Su constitucionalidad se salva en base a un argumento ya conocido: un Estatuto no puede negar las competencias que la Constitución atribuye al Estado, por lo que éste mantiene en la Comisión Mixta una posición de superioridad, pues la función de coordinación en materia financiera que le corresponde lleva implícita la idea de jerarquía. Por otra parte, la bilateralidad no excluye la existencia de los mecanismos multilaterales, recordada en el mismo artículo, que son la sede para adoptar determinadas decisiones, ni niega la obligada subordinación a la LOFCA. Los requisitos exigidos para que sean constitucionales los apartados a), b) y d) del 210.2 EC, que establece las competencias de la Comisión Mixta de Asuntos Económicos y Fiscales Estado- Generalitat, son consecuencia de lo que se acaba de señalar: «se limitan a fijar un marco bilateral de negociación y de formalización de acuerdos que complementa, sin cuestionarlo, el procedimiento general de toma de decisiones en el seno del órgano multilateral de colaboración y coordinación».

Lamentablemente, ni los mecanismos multilaterales, ni la LOFCA, ni el procedimiento general de toma de decisiones están mencionados en un Estatuto que contempla la financiación desde una lógica bilateral. Bueno sería que la LOFCA recondujera el sistema a la unidad, después de haber definido el papel de los órganos bilaterales.

\section{JAVIER GARCÍA ROCA}

La financiación es un objeto que no es a menudo susceptible de un tratamiento estatutario bilateral y la sentencia abre la puerta a las importantes funciones constitucionales de la LOFCA conforme al artículo 157.3 CE. En apretada síntesis, el Tribunal remarca el valor de los principios de coordinación y solidaridad como límites a las Haciendas autonómicas. Mantiene la constitucionalidad de la Agencia Tributaria de Cataluña. Declara que la participación catalana en los mecanismos de nivelación y solidaridad no puede condicionarse a la existencia de un esfuerzo fiscal similar, pero sí es un deber estatal garantizar que su aplicación no empeore la posición relativa de Cataluña. Y admite la validez de la Comisión Mixta de Asuntos Económicos y Fiscales como órgano bilateral de relación, pero sin excluir las competencias del Consejo de Política Fiscal y Financiera. Todo ello es prudente y adecuado a la Constitución, y en buena parte queda en manos de la LOFCA.

El estudio de la ordenación estatutaria de la Hacienda autonómica se inicia en la sentencia con una definición de los límites. El Tribunal recuerda que los Estatutos de las Co- 
munidades de régimen común pueden regular la Hacienda autonómica, pero han de hacerlo: «con arreglo a los principios de coordinación con la Hacienda estatal y de solidaridad entre todos los españoles» (art. 156.1 CE), y teniendo presente que incumbe al Estado garantizar la realización efectiva del principio de solidaridad según el art. 138.1 CE (F.J. 130).

El Tribunal Constitucional avala la competencia de la Agencia Tributaria de Cataluña para la gestión, recaudación, liquidación e inspección de los tributos cedidos totalmente por el Estado. Tanto el artículo 156 CE como la LOFCA contienen una habilitación expresa para que las Comunidades Autónomas actúen como delegados o colaboradores del Estado en esta materia, desempañando las funciones indicadas «de acuerdo con las leyes y los Estatutos». El artículo resulta constitucional porque será el legislador estatal quien defina las potestades autonómicas vinculadas a la cesión de tributos (F.J. 132º.

La regulación de los instrumentos de nivelación y solidaridad resulta el aspecto más problemático. El texto estatutario no discute la competencia estatal para definir los servicios públicos que, por su carácter fundamental, han de ser objeto de nivelación en todas las Comunidades Autónomas, así como para concretar el grado mínimo de prestación de los mismos. No obstante, condiciona la participación catalana a la existencia de un esfuerzo fiscal similar por parte de las restantes Comunidades Autónomas. A juicio del Tribunal, tal previsión resulta inconstitucional, puesto que la fijación del esfuerzo fiscal que deben realizar las Comunidades Autónomas es una cuestión que, en ningún caso, puede imponer el Estatuto a las demás Comunidades Autónomas, pues al hacerlo así se vulneran, a la vez, las competencias del Estado para fijar los niveles de contribución a estos mecanismos y el principio de autonomía financiera de aquéllas» (F.J. 134º.

Cuestión distinta es que el Estatuto imponga al Estado el deber de garantizar que la aplicación de estos mecanismos no tenga como resultado el empeoramiento de la posición relativa de Cataluña respecto de las autonomías que se benefician de su contribución. La validez de esta disposición no plantea problemas. Se limita a reiterar el mandato del artículo 138.1 CE conforme al cual la realización efectiva del principio de solidaridad debe observar un criterio de proporcionalidad, velando por el establecimiento de un equilibrio entre las diversas partes del territorio nacional. La Sentencia matiza que el precepto sólo operaría cuando el empeoramiento de la posición de Comunidad Autónoma «se debiera, no a la aplicación general de los mecanismos de nivelación, sino exclusivamente a la aportación que realizase Cataluña como consecuencia de su posible participación en dichos mecanismos» (F.J. 134º).

La Sentencia respalda la configuración de la Comisión Mixta de Asuntos Económicos y Fiscales Estado-Generalitat como el órgano bilateral de relación entre ambas Administraciones. Pero el Tribunal recuerda que las decisiones relativas a la autonomía financiera han de adoptarse en el Consejo de Política Fiscal y Financiera, cuyas actuaciones «deben integrarse con las funciones que las Comisiones Mixtas de carácter bilaterales tengan, en su caso, atribuidas en las normas estatutarias» (F.J. 130 ). En consecuencia, el Estatuto resulta conforme a la Constitución siempre que se interprete que las funciones de dicha Comisión no pueden excluir ni limitar las propias del Consejo ni afectar a la reserva de la LOFCA, ni impedir o alterar las competencias estatales en esta materia (F.J. 135\%).

Finamente, el Tribunal Constitucional restringe la eficacia de las disposiciones estatutarias que imponen un determinado contenido a las futuras leyes de cesión de impuestos $y$ a los Presupuestos Generales del Estado, pues se interpretan como compromisos carentes de 
fuerza vinculante que en nada menoscaban la libertad de las Cortes Generales para decidir sobre estos asuntos (FF.JJ. $137^{\circ}$ y $138^{\circ}$ ).

En suma, parece que el Tribunal Constitucional se asegura de que los mandatos de la LOFCA puedan primar o desplazar a las normas estatutarias por la misma necesidad de una regulación multilateral del asunto en todo el Estado y esta filosofía es la constitucionalmente adecuada.

\section{Luciano Parejo Alonso}

No soy especialista en Derecho financiero, lo que quizá pueda explicar la sensación de desorientación que suscita la lectura de la Sentencia en este punto (y que no sería así propiamente imputable a ella). En cualquier caso, dicha lectura deja al lector no experto una triple impresión de cierta contradicción interna, mayor rigor relativo en el enjuiciamiento y contribución a la ambigüedad y, por tanto, conflictividad potencial del esquema de financiación de la Comunidad Autónoma catalana.

Se aprecia cierta contradicción, por de pronto, en la facilidad con la que aquí - $-\mathrm{y}$ no así en otros aspectos del Estatuto- se llega, en materia hacendística, a la necesidad de homogeneidad del entero sistema. De ella se predica, en efecto, nada menos que la «evidencia», siendo así que el propio Tribunal razona luego — a propósito de la impugnación del artículo 201.4 del Estatuto por relación al artículo 138.2 CE- desde la no imposición por la norma fundamental de una homogeneidad absoluta al proscribir únicamente las diferencias carentes de justificación objetiva y razonable ${ }^{58}$. No queda claro, pues, cual sea la homogeneidad del sistema que deriva necesariamente de la Constitución, toda vez que se proclama conjuntamente con la generalidad y en términos impeditivos de decisiones unilaterales, siendo así que la homogeneidad y la generalidad no son entidades idénticas y ambas se mueven, a su vez, en plano diferente al de la multi-, bi- o unilateralidad de las decisiones.

La combinación, cuando de financiación se trata, de aplicación de criterio de enjuiciamiento más estricto y cierta inconsecuencia con la lógica del sistema resultante de tal criterio que de esta forma se asume, luce decididamente ya — gracias, de nuevo, a la aplicación al límite de la técnica de la interpretación conforme- en el tratamiento del papel atribuido a la Comisión Mixta de Asuntos Económicos y Fiscales Estado-Generalitat. En un primer paso, la posición es clara y tajante: las decisiones en la materia han de ser adoptadas por el Estado central y en el ámbito estatal de actuación, es decir, en el pertinente órgano multilateral en el que aquél ejercita sus funciones de cooperación y coordinación. Pero si esto es así y, por tanto y en un segundo momento, la Sentencia parece implícitamente reconocer que la función de desarrollo del Estatuto atribuida a la citada Comisión Mixta no es compatible con la estructura y el funcionamiento del sistema constitucional, en cuanto basado en la homogeneidad y la generalidad, ¿cómo es posible la validación interpretativa de la regulación del papel de la Comisión en cuestión vía tan sólo el artícu-

58 Como, por ejemplo, el condicionamiento de la aportación a la nivelación de los servicios fundamentales y la solidaridad, en el artículo 206 del Estatuto, mediante la exigencia de un esfuerzo fiscal similar por las restantes Comunidades Autónomas; condicionamiento que, por ello, se declara efectivamente inconstitucional. 


\section{ENCUESTA SOBRE LA SENTENCIA DEL TRIBUNAL CONSTITUCIONAL 31/2010, DE 28 DE JUNIO}

lo 175.2 del Estatuto? Solo «olvidando» que su referencia a la colaboración de la Generalitat en órganos multilaterales posibilitadora de su enmarque por el Tribunal en el esquema de cooperación y coordinación previsto por la norma fundamental aparece decisivamente matizada por el adverbio «también», el cual diluye la exigencia predicable de la doble nota de la homogeneidad-generalidad cuando menos por lo que hace al funcionamiento del sistema. Cuando menos este proceder no contribuye a clarificar (erradicando la semilla de posibles conflictos precisamente interpretativos) el funcionamiento del subsistema de financiación de Cataluña en el seno del sistema general. Tanto más, cuanto que simplemente obvia —igualmente «por elevación» al plano abstracto de la construcción que el propio Tribunal hace del sistema de financiación autonómica y gracias a una interpretación «creadora»- la precisa e inequívoca regulación estatutaria (art. 210) de las competencias de la Comisión Mixta.

Justamente este último es el reproche de que es susceptible el análisis de las potestades de gestión de la Agencia Tributaria de Cataluña. La acertada contundencia con la que se despeja la competencia para el establecimiento mismo de la Agencia y se rechaza la pertinencia al respecto de la observancia de un supuesto principio de reciprocidad respecto del poder central cede inmediata y sorprendentemente el paso a un tratamiento de la competencia y organización estatales. En modo alguno es obvio, cual sin embargo - y sin base alguna distinta de la propia construcción teórica - afirma la Sentencia, que la clara y directa $^{59}$ delegación a la Agencia (art. 204.1 del Estatuto) de las competencias estatales sobre los tributos cedidos pueda convertirse en una delegación en la medida y en los términos de lo que dispongan las Leyes estatales de cesión. Lo impide no solo el tenor del aludido precepto estatutario, sino, ya definitivamente, el apartado 4 del propio artículo cuando vincula el legislador autonómico regulador de la Agencia justamente a aquel precepto (la Agencia — dice después de encomendar a la Ley su creación- dispone de plena capacidad y atribuciones para la organización y el ejercicio de las atribuciones a que se refiere el apartado 1). De nuevo aquí, pues, una interpretación conforme forzada, haciendo decir a la norma lo que no dice, a costa, además, del perfil del espacio organizativo y competencial del poder central ${ }^{60}$.

59 Es decir, sin intermediación y con independencia de las Leyes estatales de cesión. Interesa precisar que la argumentación que se desarrolla no pone en cuestión la viabilidad misma de la delegación, limitándose a cuestionar que ésta pueda efectuarse desde el propio Estatuto.

60 Lo mismo no puede decirse paradójicamente de la revisión en vía administrativa de los actos de gestión tributaria. Aquí la ambigüedad que proviene ya del tenor literal del artículo 205 del Estatuto propicia sin duda la interpretación que hace el Tribunal Constitucional. Y ello aún cuando sea más que cuestionable la afirmación de que la referencia estatutaria a los propios órganos económico-administrativos 
7. ¿En la medida en que considere viable emitir una opinión de conjunto, ¿podría sintetizar los aspectos, a su juicio, más afortunados de la Sentencia del alto Tribunal que nos ocupa y los que habrían sido mejorables?

\section{ROBERTO BLANCO VALDÉS}

Creo que un balance de conjunto de la Sentencia del TC sobre el Estatuto catalán exige no sólo referirse al modo en que aquella ha afectado a la norma estatutaria sino realizar también una breve reflexión en relación con cómo ha influido en el Tribunal que la ha dictado e, incluso más allá, en la propia función estatal de control de la constitucionalidad. De hecho uno y otro asunto están íntimamente ligados, según ya se enunciaba al contestar a la primera de las preguntas de este cuestionario.

A mi juicio —que, me parece, es ampliamente compartido en los círculos científicos, pero también en los políticos-, el Tribunal ha salido muy lesionado de lo que podríamos denominar, para entendernos, la batalla estatutaria. Ello ha tenido que ver, en parte, como era de esperar y como, también en parte, resultaba probablemente inevitable, dado el objeto de la Sentencia del TC, con su propio contenido material que, quizá por la evidente voluntad del Tribunal de contentar a todo el mundo, acabó finalmente por no gustar a casi nadie en el ámbito político. De hecho, sólo el Gobierno, que optó por intentar salir bien parado de un asador en el que había puesto mucha carne simulando que la Sentencia tenía un significado distinto del que tenía en realidad, terminó por defender sus contenidos: según él, el Tribunal habría venido a darle por completo la razón al anular previsiones normativas que afectaban tan sólo a 14 artículos de la norma estatutaria. Algún Ministro, que antes de serlo había oficiado de valedor de la completa constitucionalidad del texto, llegó incluso a medir la supuesta victoria del Gobierno aludiendo expresamente al número concreto de palabras (desconozco si de sílabas) afectadas por la inconstitucionalidad: todo ello significaba, sin embargo, desconocer que más allá de esas ciertamente escasas declaraciones de inconstitucionalidad, el TC había procedido a vaciar de contenido otras muchas normas estatutarias al interpretar previsiones que afectaban a 27 artículos, que se llevaban al fallo, y aún a 49 más, que, por motivos ignotos, el supremo interprete decidía no incluir en el fallo de su pronunciamiento. Si a tal dato cuantitavio se añade el hecho cualitativo de que entre las materias afectadas por la declaración de inconstitucionalidad o la técnica de la interpretación conforme (constasen o no tales intrepretaciones en el fallo) están las más relevantes del Estatuto catalán (derechos históricos y definición nacional, lengua, competencias, bilateralidad, participación de la Generalitat en órganos del Estado, Consejo de Garantías Estatutarias, Consejo de Justicia y financiación) parece obvio que el triunfalismo del Gobierno, único actor político que se manifestó encantado con la Sentencia, tenía más de estrategia de disimulo (de hacer de la necesidad virtud) que de satisfacción auténtica y sincera.

Ahora bien, sea como fuere, la verdad es que el contenido de la Sentencia 31/2006, tal y como ya antes se apuntaba, contribuyó sólo en parte a lesionar seriamente el prestigio que el TC había sido capaz de ganarse con su buen hacer y sentido del Estado desde su creación hace tres décadas. Sólo en parte, en efecto, porque esa triste (para muchos trágica) lesión procedió también, y sobre todo, de la inaceptable forma en que el TC re- 
solvió el pleito, ciertamente endiablado, que se le había planteado. Me estoy refiriendo, como es obvio, al injustificado e injustificable retraso por virtud del cual un órgano fundamental del Estado democrático iba a tardar cuatro años en emitir una sentencia que tenía la obligación legal de haber pronunciado en pocos meses, pero también a todo lo que pasó durante esos cuatro largos años: a las peleas internas en el Tribunal, filtradas casi de forma permanente a los medios de comunicación, que, con más o menos razón, trataban (y tratan) todas las noticias procedentes de ese órgano como si aquel fuese en realidad un miniparlamento jurisdiccional, donde la oposición entre los magistrado calificados como progresistas y como conservadores aparecía casi siempre equiparable a la que existe entre partidos en los parlamentos democráticos. Aunque el episodio más sonado de esa greña interna, transmitida en directo a la opinión pública, fue el de las recusaciones, también otros varios llevaron a que se instalase en gran parte de la sociedad la idea de que el Tribunal no era un órgano imparcial, compuesto por magistrados independientes sujetos sólo a los mandatos de la Constitución, sino la mucho más perversa de que los magistrados decidían a la postre según lealtades tan supuestamente evidentes como realmente inconfesables. La situación de deterioro institucional alcanzó tal grado, que personalidades nada sospechosas de irresponsabilidad o demagogia, como el ex líder de CiU Miquel Roca, llegaron a proponer, meses antes de que se pronunciase la Sentencia 31/2006, soluciones en verdad excepcionales, como que el Tribunal fuese renovado en su totalidad tras una dimisión en bloque de sus doce componentes. No es, por ello, difícil concluir que el pleito catalán ha tenido un altísimo coste para el TC, que ha perdido en el camino una gran parte del prestigio que con sólidos motivos había logrado previamente acumular, pero que lo ha tenido también para la función estatal de control de la constitucionalidad, cuyo desarrollo por parte del órgano estatal encargado de llevarla a cabo fue objeto durante muchos meses de profundas e inadmisibles presiones políticas, sociales e institucionales y cuyos resultados finales han sido juzgados por las partes y sus aliados de todo tipo en función de un único criterio: el mayor o menor porcentaje de razón que ha dado el Tribunal a recurridos y recurrentes.

¿Quién de ellos ganó el pleito constitucional que resolvió la Sentencia 31/2006? Para contestar esta pregunta, que es la forma en que comenzaré a referirme a la cuestión de cómo la Sentencia del TC afectó a la norma estatutaria, cabría echar mano de la metáfora de la botella medio vacía o medio llena. Y ello porque, dejando de lado las posiciones adoptadas desde una exclusiva óptica política («el Estatuto ha salido prácticamente indemne del TC», sostenida por el Gobierno versus «el Estatuto ha sido arrasado por completo por el TC», mantenida por el nacionalismo catalán) el juicio técnico-jurídico sobre la significación constitucional del contenido material de la Sentencia depende en gran medida del punto de vista en el que se coloque el juzgador. Para los que creen que el TC ha anulado, o vaciado por medio de la técnica de la interpretación conforme, todas o la mayor parte de las previsiones inconstitucionales que contenía el Estatuto, la botella está, por supuesto, medio llena. Pero está medio vacía para los que opinan debería ahora decir opinamos- que el TC ha utilizado la técnica de la interpretación conforme con la manifiesta voluntad de evitar anular previsiones que en realidad deberían haber sido declaradas inconstitucionales a partir de los propios principios de partida que aquel iba sentando en su Sentencia. No ejemplificaré ahora lo que acabo de apuntar, pues a lo largo de las respuestas anteriores he hecho constante referencia a la cuestión. Sí me 
parece necesario, en todo caso, ya para acabar, subrayar dos aspectos esenciales respecto de la acción jurisdiccional del Tribunal: que existen sobrados motivos para pensar que una buena parte de los artículos salvados in extremis de la inconstitucionalidad por medio de la técnica de la interpretación conforme no lo hubieran sido si el TC no hubiera tenido que decidir en la situación de tremendas presiones políticas, sociales e institucionales que a favor de la plena constitucionalidad del Estatuto se produjeron durante los meses en que finalmente se debatieron las sucesivas ponencias presentadas para llegar a una Sentencia. Por decirlo de otro modo, la gran deferencia hacia el legislador que lleva al Tribunal a hacer decir a muchos artículos del Estatuto lo contrario de lo que a todas luces prevén para salvarlos de la inconstitucionalidad no fue el fruto del conveniente self-restraint con el que todo Tribunal Constitucional debe actuar, sino de la decisión de la mayoría del órgano jurisdiccional de emitir una Sentencia que no lesionase políticamente a los defensores de la norma estatutaria, lo cual es a todas luces muy distinto: el Tribunal hizo todo lo posible para salvar la constitucionalidad de los preceptos impugnados (lo cual no puede criticársele, pues así debe actuar un órgano de su naturaleza), pero también hizo lo imposible, al forzar interpretaciones que nada tienen que ver con lo que cabe deducir de las normas que procedía a interpretar. De hecho, no es difícil concluir que fue, a la postre, la antes aludida decisión la que llevó a la corta mayoría que sacó adelante las distintas votaciones que permitieron la aprobación de la Sentencia la que determinó que el TC utilizase la técnica de la interpretación conforme de un modo impropio y desviado, no para señalar, como cabía esperar, la o las interpretaciones compatibles con la Constitución de una previsión normativa que admite interpretaciones diversas, sino para señalar como interpretación adecuada a la Constitución la que en ningún caso cabe deducir del precepto interpretado. Ello obligó al Tribunal a retorcer una y otra vez el texto literal de los artículos, para hacerles decir no sólo lo que evidentemente no decían sino incluso, en reiteradas ocasiones, para hacerles decir todo lo contrario de lo que abiertamente disponían. La indudable inseguridad jurídica de tal forma de juzgar se ha multiplicado además por el hecho de que el TC recurrió a la técnica de la interpretación conforme en muchos casos sin llevarla al fallo, algo que sólo hizo en relación con 27 de los 76 artículos afectados por una declaración interpretativa. Ello quiere decir que hay 49 artículos del Estatuto afectado por interpretaciones del Tribunal que deben ser rastreadas en su Sentencia, toda vez que el TC ha decidido, sin que sea fácil de adivinar por qué motivo, no incluirlas en el fallo. Sólo el tiempo dirá si esta timorata forma de actuar contribuirá a posibilitar una aplicación del Estatuto conforme a la Constitución o a todo lo contrario, es decir, a convertir la Sentencia del TC en papel mojado en todo aquello en que aquel optó por interpretar conforme a la Constitución, en lugar de anular lo que no cabía en la misma. Algunos de los acontecimientos que se han producido tras la aprobación de la Sentencia, como la voluntad del Gobierno de rescatar algunos preceptos anulados a partir de supuestas interpretaciones del TC que según el ejecutivo lo permitirían y la decisión de la Generalitat de incumplir abiertamente fallos del Tribunal Supremo en materia lingüística dictados en coherencia con la doctrina del TC en su Sentencia 31/2006, no animan a ser optimistas sino, más bien, a todo lo contrario. 


\section{RAÚl CANOSA USERA}

Se trata de una sentencia que pretende ser clara y precisa (y en ocasiones lo consigue); ayuda a recuperar el prestigio del TC. En la sentencia se plantean dramáticamente los límites del poder estatuyente y, de manera subyacente, su diferencia con el poder de reforma constitucional, enlazando esta problemática con la titularidad de cada cual. En lo esencial, la STC 31/2010 acierta cuando despeja cualquier duda acerca de la titularidad de la soberanía, recalcando que sólo hay una Nación — la española— que ostente la competencia de la competencia, y que su decisión, formalizada en la Constitución, no es disponible ni para el legislador orgánico ni para el estatuyente. Tampoco éste se haya legitimado para cerrar la apertura deseada por el constituyente. Sentada esta premisa, el TC permite, sin embargo, que el Estatuto «sugiera» al legislador orgánico determinados contenidos para sus leyes, aunque sin condicionarlo. Se da entonces la bizarra situación de que ciertos preceptos estatutarios, al permitírseles subsistir, quedan degradados de verdadera eficacia.

Al llevar lo anterior al terreno competencial, el TC advierte con acierto, a mi parecer, que no cabe en los Estatutos definir el alcance de las competencias estatales, lo que hubiera producido una asimetría intolerable ya que, de lo contrario, las competencias estatales habrían tenido respecto de Cataluña una proyección diferente.

En una cosa importante la STC 31/2010 sigue la línea de la STC 247/2007, la relativa a los derechos estatutarios, degradados a meros mandatos para el legislador autonómico. En esta misma Revista me he pronunciado al respecto y he sostenido que, si bien ese aserto pudiera predicarse del derecho al agua valenciano, no era sin tacha trasladable a una declaración estatutaria de derechos como la catalana o la andaluza o alguna más que cuidadosamente distinguen entre verdaderos derechos subjetivos y principios rectores. Negar su condición de derechos con una argumentación apodíctica no es plausible. O en un Estatuto pueden declararse derechos o no se puede; la solución de hacer decir al Estatuto lo que no dice para así consagrar su constitucionalidad es camino criticable que el TC emplea en esta materia y en otras conformando una gigantesca sentencia interpretativa, muchas veces sin reflejo en el fallo. Este exceso no dejará de generar dudas que el propio TC habrá de aclarar en el futuro.

\section{FranCESC DE CARreras SERra}

Lo más significativo y positivo de la sentencia es que desactiva los principales objetivos inconstitucionales que se había propuesto el proyecto de estatuto aprobado por el Parlamento de Cataluña. Ya en su paso por el Congreso el estatuto fue profundamente modificado para que se ajustara a la Constitución; sin embargo, quedaron pendientes algunos flecos importantes y bastantes ambigüedades. Unos y otras han sido, en general, bien detectados por la sentencia que, por unas vías u otras — nulidad, interpretación conforme llevada al fallo o interpretación conforme en la ratio decidendi de los fundamentos - restituye, con mayor o menor claridad y contundencia, la integridad constitucional del ordenamiento mediante un Estatuto que, a luz de la sentencia, a pesar de que la li- 
teralidad de sus preceptos no han variado mucho, es una norma muy distinta a la que fue aprobada en su momento.

Además, dos aspectos de tipo formal están en el haber de la sentencia. Primero, dada la enorme cantidad de normas impugnadas (unas doscientas, contenidas en 128 artículos), se trata de una resolución breve debido, sobre todo, a que su estructura es distinta de la habitual: expone los argumentos de las partes en los antecedentes y sólo traslada a los fundamentos algunas someras indicaciones sobre los mismos (señalando, para facilitar su lectura a fondo, el número del epígrafe en que están consignados) para que los razonamientos del Tribunal sean comprensibles. Con ello, la argumentación de los fundamentos gana en claridad y concisión, algo especialmente importante para la eficacia jurídica de aquellos muchos preceptos cuya interpretación conforme no es llevada al fallo. Segundo, el tipo de argumentación más frecuente se basa en jurisprudencia constitucional ya muy consolidada, citando a este respecto no todas las sentencias que la contienen sino sólo la de aquellos leader case en la que está mejor y más argumentadamente formulada, ahorrándose así inútiles repeticiones, un vicio creciente en la jurisprudencia de los últimos años del que es exponente claro, entre muchas otras, la sentencia 247/2007 sobre el estatuto de la Comunidad Valenciana.

Respecto a cuestiones de fondo, dos son también los aspectos positivos más destacados. En primer lugar, pese a la abundancia de votos particulares, la sentencia expresa un amplio acuerdo doctrinal básico en el que fundamentar la inconstitucionalidad de determinados preceptos del Estatuto. El bloque de seis magistrados que suscribe la casi totalidad de la sentencia - con dos excepciones en lo que se refiere a ciertas expresiones del preámbulo - es una mayoría ajustada pero suficiente. Ahora bien, más que esta mayoría numérica, lo que da fuerza a la sentencia es la coincidencia entre las razones de esta mayoría con los argumentos de fondo expuestos en tres de los votos particulares, los suscritos por los magistrados Vicente Conde, Ramón Rodríguez Arribas y Javier Delgado. En efecto, la principal discrepancia consiste en el contenido del fallo: para unos es posible una interpretación conforme que no conduzca a la nulidad del precepto, para los otros esta interpretación conforme no es admisible y un gran número de preceptos son radicalmente nulos y, por tanto, así debe constar en el fallo para que sean expulsados del ordenamiento. Ello supone, por tanto, que por lo menos nueve de los diez magistrados que forman el pleno, han llegado a un acuerdo de fondo sobre las razones de inconstitucionalidad de ciertas partes del Estatuto, lo cual dota de una amplia legitimidad a la doctrina constitucional que emana de la resolución.

En segundo lugar, las bases conceptuales de toda la sentencia están sucintamente razonadas en los fundamentos 3 a 6 (y también en el 57, en lo referente a las competencias), unas pocas páginas que reafirman la naturaleza jurídica y la función de los estatutos dentro del ordenamiento jurídico, un aspecto básico para analizar el juicio de constitucionalidad sobre la norma recurrida, cuestión que no quedaba clara ni en el texto estatutario, ni tampoco en ciertas ambigüedades y contradicciones de la STC 247/2007, que abordó también esta materia. Ciertamente, la doctrina sobre la naturaleza y función de los estatutos no es nueva respecto a la anterior doctrina constitucional; al contrario, lo que aclara la sentencia es que sigue siendo la misma, es decir, reafirma algunos principios básicos que estaban ya bien asentados y que si hubieran sufrido cambios transformarían la naturaleza del Estado de las autonomías. Entre ellos, cabe resaltar algunos principios tan 
obvios como, por ejemplo, los siguientes: 1) un estatuto es una norma subordinada a la Constitución porque su fuente es un poder constituido y no uno constituyente; 2) los estatutos atribuyen competencias a la comunidad autónoma, de la que son norma institucional básica, pero no pueden modificar ni delimitar las competencias del Estado garantizadas en el art. 149.1 CE; o 3) la relación de los estatutos con las demás normas que forman parte del bloque de la constitucionalidad se rige por el principio de competencia, no por el de jerarquía. Éstos, y otros subprincipios derivados de los mismos, permiten desbaratar la teoría jurídica formulada por algunos juristas catalanes con la intención de justificar constitucionalmente el proyecto estatutario, impidiendo así los objetivos que éste se proponía. Para una tratamiento más detenido y argumentado de todo ello, véase mi artículo «¿Es constitucional el Estatuto de Cataluña?», Claves, num. 206, octubre de 2010, en especial los epígrafes 1 y 3.

Dos son también, a mi parecer, los aspectos más negativos de la sentencia: la excesiva amplitud de las materias susceptibles de ser reguladas en un estatuto y el abuso de la técnica de la interpretación conforme.

Me he referido al primero cuando he aludido al contenido de los estatutos en respuesta al epígrafe 4 de este cuestionario y allí remito al lector. Son comprensibles como hemos expuesto, creo, razonadamente - las dificultades de llegar a un consenso amplio entre los magistrados del Tribunal respecto a determinadas cuestiones, así como el esfuerzo intelectual en delimitar el contenido de la materia estatutaria, un aspecto esencial del régimen jurídico de las comunidades autónomas que no había sido abordado por la jurisprudencia hasta la STC 247/2007. Ahora bien, si recordamos lo dicho en el epígrafe 4 de este cuestionario, y más aún si hacemos una lectura detenida de los fundamentos jurídicos 4 a 6 de la sentencia, podremos comprobar que los criterios para delimitar el ámbito material estatutario son muy abstractos y bastante indeterminados. Además, la aplicación de estos criterios al enjuiciamiento de algunas de las normas estatutarias ha sido demasiado generosa. Nuestra Constitución contiene una gran cantidad de tipos normativos, en muchos casos derivados de su ámbito material, como es el caso de las leyes orgánicas o de la ley de presupuestos. El Tribunal ha sido casi siempre muy estricto en la determinación de la esfera material atribuible a cada tipo de norma. En cambio, en este supuesto, su criterio ha sido de una gran amplitud y no ha considerado nulos por razón de materia algunos preceptos cuyo contenido, aplicando su propia doctrina, no debería formar parte de un estatuto.

Es, muy probablemente, el caso de ciertos derechos y deberes que se regulan en el Estatuto y es, sobre todo, el caso de ciertas normas estatutarias que pretenden vincular al legislador estatal. Ambos supuestos pueden generar confusión en el futuro legislador, sea estatal o autonómico. Dejemos de lado el caso de los derechos y deberes — ya resuelto con pragmatismo mediante el «bajonazo» torero de considerarlos meros mandatos al legislador - y ciñámonos al supuesto de normas que pretenden vincular a órganos constitucionales estatales, como es el caso, por ejemplo, de los arts. 180 a 183 EAC y bastantes de los preceptos que sobreviven en el título dedicado al poder judicial. A pesar de que la mayoría del Tribunal se inclina por interpretar, como ya hemos dicho, que el Estado central es absolutamente libre en regular aquellas materias en que es competente y que en modo alguno puede estar condicionado por un estatuto, más riguroso y claro hubiera sido considerar que estas normas son nulas porque no hay razón alguna para que 
sean incluidas en un estatuto de autonomía, una ley que por su naturaleza tiene un ámbito territorial acotado y que, además, no forman parte, ni de forma conexa, del contenido estatutario constitucionalmente permitido en el art. 147 o cualquier otro precepto constitucional. En definitiva, creo que aún aceptando la idea de contenido estatutario que se expone en la sentencia, la aplicación que se hace de la misma a determinados preceptos impugnados es excesivamente generosa.

El segundo aspecto negativo es que, en ocasiones, el Tribunal abusa de la interpretación conforme. Este tipo de interpretación, aceptable y muy utilizada para salvar determinados preceptos mediante la modulación de su significado en nombre del clásico principio de conservación de las normas y del respeto que es propio de los tribunales por la labor del legislador democrático, tiene un claro límite: que lo interpretado no sea contrario a la literalidad de la norma cuestionada al no admitir ésta otro significado que el que se desprende de su sentido gramatical. En este caso, como se argumenta acertadamente en alguno de los votos particulares, el juez se convierte ilegítimamente en legislador, no respetándose así la división de poderes ni las reservas que, por consiguiente, estos poderes tienen exclusivamente asignadas. Pues bien, en los fundamentos de la sentencia se ha cometido en ciertos casos esta irregularidad (así lo hemos señalado antes en el art. 5 EAC referido a los derechos históricos y en algunos preceptos relativos a la regulación lingüística, como son los arts. 33.5, 34, 35. 1 y 2, y 50.5, todos EAC). En esta sentencia, quizás con más razón que en ninguna otra en toda la historia del Tribunal Constitucional, puede justificarse evitar la nulidad y efectuar una, incluso forzada, interpretación conforme con el objetivo de alcanzar una mayoría suficiente que logre poner fin al litigio. Pero de ninguna manera es aceptable retorcer el significado del precepto haciéndole decir lo contrario de lo que literalmente prescribe sin otra razón aparente que impedir su radical nulidad.

\section{MARC CARrillo LÓPEZ}

Como he puesto de manifiesto al responder a la primera pregunta acerca del proceso previo que condujo al Tribunal a dictar la STC 31/2010, la valoración que pueda hacerse de la misma no puede hacer abstracción de un contexto político institucional que no ha sido especialmente favorable para el Tribunal. Por razones internas y, por supuesto, también externas, el proceso de cuatro años para deliberar y aprobar la sentencia no ha sido positivo y ha supuesto un incuestionable desgaste institucional del Tribunal. En otro tiempo, uno de los órganos constitucionales del Estado y del sistema democrático español con mayor y reputado prestigio. Un prestigio que, desafortunadamente, ha aminorado en grado sumo no solo con ocasión del largo episodio protagonizado con ocasión de la sentencia del Estatuto de Cataluña, sino también por episodios poco afortunados que procedían de los años inmediatamente precedentes.

Por vez primera, con la STC 31/2010, el Tribunal se ha encontrado con la tesitura de tener que enjuiciar, en primer lugar, un Estatuto de autonomía en su práctica integridad, por la interposición de un recurso de inconstitucionalidad que cuestionaba en un alto porcentaje la constitucionalidad de buena parte de su contenido. Y en segundo lugar, 
además, un Estatuto que fue sometido y aprobado en referéndum por la población de Cataluña.

El resultado ha sido una sentencia formalmente extensa pero materialmente corta, sobre todo porque sus razonamientos son breves. En efecto, los mismos se han construido a partir de una argumentación de corte taxativo, que no admite la contradicción, su tenor es especialmente apodíctico, lo cual resulta decepcionante sobre todo si se tiene en cuenta que la reforma estatutaria catalana suponía una evidente novedad respecto de los estatutos que dieron inicio al Estado de las autonomías.

Asimismo, con la lógica de atenerse como vía de seguridad a lo ya conocido jurisprudencialmente, cabe subrayar que en la inmensa mayoría de sus fundamentos jurídicos, el Tribunal construye su argumentación con una reiterativa referencia a su jurisprudencia anterior que, en este sentido, aparece como una especie de canon codificado, sin que las novedades jurídico-normativas que el Estatuto presentaba sirviesen para que el Tribunal aceptase el reto de interpretarlas a la luz del cambio que suponía el nuevo Estatuto, como parte integrante del bloque de la constitucionalidad. El Tribunal lo rechaza y se refugia en su jurisprudencia (pero sólo instrumentalmente, pues no lo hace a toda ella), para negar el carácter complementario de la Constitución que el Estatuto como norma había de tener y que así le reconocía en la STC 247/2007 (FJ 6) relativa a la reforma del Estatuto de la Comunidad Valenciana. Ahora desvirtúa su rango jurídico y rechaza que pueda ser parámetro de constitucionalidad para la determinación de las competencias: esta condición únicamente la puede tener la Constitución y la jurisprudencia del Tribunal Constitucional, acogiéndose con ello a la cuestionable teoría que concibe la jurisdicción constitucional como un comisionado del poder constituyente ${ }^{61}$; posición cuestionable si con ello se olvida que el Tribunal siempre será un poder constituido a quien se encomienda interpretar la Constitución y, en el caso español, el bloque de la constitucionalidad del que el Estatuto forma parte.

La sentencia trasluce también una constante desconfianza cuando no un evidente recelo respecto de la reforma estatutaria, que aparece de manera más intensa en los temas relacionados con los elementos simbólicos o la lengua, donde creen verse objetivos ocultos. Sin duda, el ejemplo más significativo de ello se encuentra en la decisión de llevar al fallo la ausencia de eficacia jurídica interpretativa de las referencias del Preámbulo a «Cataluña como nación» y a «la realidad nacional de Cataluña».

Otro aspecto de orden jurisdiccional de decisiva importancia es el empleo de la decisión interpretativa que la sentencia utiliza para resolver el objeto del recurso. Como es sabido, algunas de las conclusiones interpretativas han sido llevadas al fallo explícitamente, pero es lo cierto que en una buena parte de la sentencia, sobre todo en el decisivo Título IV referido a las competencias, la STC 31/2010 resuelve la litis que plantea cada caso, a través de decisiones interpretativas que si bien no son llevadas al fallo, de hecho, en realidad no dejan de ser decisiones falsa o vergonzantemente interpretativas, porque su efecto práctico, por utilizar una expresión ya citada anteriormente, no es otro que el desactivar el alcance de la reforma estatutaria.

61 Vid. E. García de ENTERría, La Constitución como norma jurídica y el Tribunal Constitucional, Thompson Civitas, $4^{\mathrm{a}}$ ed., 2006, pág. 209. 
Finalmente, sorprende en grado sumo que en su enjuiciamiento acerca de la constitucionalidad de la reforma estatutaria, la sentencia no entre en ningún momento a valorar que en íter prescrito por la Constitución para su aprobación, y una vez aprobada la proposición por las Cortes Generales, la misma fue sometida a referéndum. La incidencia que el ejercicio de este instrumento de participación política directa pudiese tener como factor añadido de un plus de legitimidad política de la norma institucional básica, no ha sido expresamente evocada por el Tribunal en su sentencia. Lo cual no deja de sorprender si como es preceptivo en el juicio de constitucionalidad, y siempre que lo admita la jerarquía normativa de la Constitución, el Tribunal no puede dejar de tener presente el principio de deferencia frente al legislador autor de la ley impugnada. En este caso, una ley orgánica que daba forma a un Estatuto aprobado antes en referéndum. Una ley orgánica, por esta razón, mucho más rígida que cualquier otra

Más allá del mayor o menor número de artículos afectados por una declaración de inconstitucionalidad o por una decisión interpretativa, incorporada o no al fallo, por las razones que expongo en las respuestas a las preguntas formuladas, lo cierto es que la STC $31 / 2010$ ha desnaturalizado la reforma estatutaria. No obstante, el futuro más inmediato habrá de permitir constatar si dicha sentencia ha sido un episodio jurisdiccional susceptible de ser superado por interpretaciones más deferentes o bien si con ella se ha fijado un punto de no retorno en la configuración de la autonomía política de las CCAA.

Permítaseme hacer una breve reflexión metajurídica al respecto: es del todo evidente que la relevancia jurídica y política de la sentencia ha sido indudable. Ciertamente, está por ver su trascendencia futura y quizás no todo ya está escrito sobre el autogobierno de las CCAA en general y de Cataluña en particular. Pero objetivamente, la Constitución que fue votada, apoyada y defendida por la inmensa mayoría de ciudadanos de Cataluña en 1978, podría correr el peligro de dejar de ser el referente democrático que ha sido en esta Comunidad Autónoma. Máxime cuando antes y sobre todo después de la STC 31/2010, la Constitución pretende ser monopolizada y es invocada por sectores accidentalistas que no la votaron en 1978 y que ahora se arropan en ella instrumentalmente.

\section{JAVIER Corcuera ATIENZA}

La sentencia ha cerrado un debate que amenazaba con eternizarse, y lo ha hecho confirmando la vigencia de lo que venía interpretándose como modelo constitucional de organización territorial, que no puede modificarse desde un Estatuto. Cierto es que lo ha plasmado en un texto que ha tenido que atender a muchos factores, buena parte de ellos de carácter más político que jurídico. Ello explica la búsqueda de vías que evitaran la declaración de inconstitucionalidad de preceptos que pueden tener una lectura constitucional. Tal y como estaban las cosas parecía el único camino para que hubiera sentencia. La consecuencia es obvia: imprecisiones, contradicciones, riesgo de subordinación de la aplicación de la doctrina constitucional a la actividad normativa de legisladores y administraciones y, de hecho, mantenimiento de la emulación y de no pocas indefiniciones.

Pero señalar estas insuficiencias no supone necesariamente identificarlas con aspectos mejorables. Tal y como se plantearon las cosas en el principio, quizá la sentencia no ha sido la mejor de las imaginables, pero sí puede estar entre las mejores de las posibles. 


\section{JAVIER GARCÍA ROCA}

Como ya he explicado, el aspecto más desafortunado de la sentencia es el déficit de integración política que produce en sus primeras páginas, el malestar en su vínculo con el Estado que el proceso parece haber creado en Cataluña y que la sentencia no ha impedido con habilidad. No creo pueda sostenerse con sensatez — como tiende ahora a decirse - que después de la sentencia todo el mundo se ha olvidado del Estatuto incluso en la campaña electoral, basta con observar la realidad política. Hay un antes y un después en la consideración de la vía estatutaria. Tras la STC 31/2010, el Pulsómetro de la SER publicó unas estadísticas según las cuales había un 42’3\% de ciudadanos que deseaban la independencia de Cataluña el 10 de noviembre de 2010, mientras el 22 de octubre de 2003 antes de iniciarse el proceso eran sólo un 30\%; significativamente, un 35’3\% de los votantes del PSC, un partido de ámbito estatal, se manifestaban a favor de esa opción, y un 64'6\% de ICV y un 60'5\% de CiU. Es lógico pensar que este preocupante incremento, que es menester detener, pueda tener algo que ver con la imagen proyectada sobre la vía estatutaria. Éste es el problema principal: algo debemos haber hecho mal. ¿Cómo encontrar instrumentos futuros de acuerdo e integración política? El camino de la unidad no pienso que pase por bruscas declaraciones de nulidad o impugnaciones generalizadas que prolonguen los conflictos sino por hallar caminos de diálogo. Por más que convenga también hablar claro -como ha recomendado el antiguo ministro de relaciones intergubernamentales Stéphane Dion partiendo de la experiencia de Quebecq_, y fijar los límites jurídicos infranqueables que marca la Constitución y el poder de reforma; y era patente la existencia de excesos e inconstitucionalidades en el Estatuto. Y asimismo explicar muy claro los elevados costes económicos para los contribuyentes catalanes que supondría la independencia, al deber asumirse de forma independiente todo tipo de servicios públicos hoy comunes como son la defensa y fuerzas armadas, la protección de las costas, las embajadas y relaciones internacionales, los diversos transportes, y un largo etcétera.

En el terreno jurídico, me parece en líneas generales correcto lo que se dice sobre las competencias del Estado y de las Comunidades Autónomas, que es el tema central, y el entendimiento de la bilateralidad. Es prudente no haber resuelto en este momento los numerosos conflictos competenciales virtuales o preventivos que el Estatuto suscita. La solución se corresponde con una jurisprudencia constitucional muy consolidada sobre el rechazo de conflictos hipotéticos, no puede presumirse la inconstitucionalidad, y es inteligente y operativa pues permite esperar a futuros ejercicios competenciales y ganar tiempo para generar acuerdos. Por más que esta opción pueda resultarle a alguno tediosa, la historia de nunca acabar, pues nos obliga a no dar por cerradas las controversias competenciales. Pero esa es la especificidad de los juicios de inconstitucionalidad en materias competenciales y la prudencia inherente a toda jurisdicción y, con mayor razón, constitucional.

También es sensato lo que se dice en materia de financiación y el papel que se asegura a la LOFCA en la ordenación multilateral del asunto, evitando el riesgo de componer un sudoku ingobernable en los Estatutos. Éste va a ser el tema más importante en el futuro, donde se juegue la unidad de España, y habrá que diseñar un buen sistema de mecanismos de nivelación y compensación, por el momento barrunto que la LOFCA diseña demasiados fondos... De nuevo, es obsoleto y un dislate que la Constitución no diga 
nada sobre esta cuestión dotada de manifiesta supremacía constitucional y un motivo más en pro de la reforma constitucional.

Son adecuados al modelo de la Constitución, los pronunciamientos efectuados sobre los límites a la descentralización del Poder Judicial y la reserva constitucional a la LOPJ. Y acerca de la inviabilidad de un Consejo de Justicia por desconcentración del Consejo General del Poder Judicial y lo menguado de sus competencias respecto de la administración al servicio de la administración de justicia, que no creo justifiquen los costes de su erección, ya tenemos bastante medicina con el Consejo... Pero el incremento de las competencias de los TSJ podría perfectamente hacerse en una reforma de la LOPJ. Es más discutible que se rechazara el carácter vinculante a los dictámenes del Consejo Consultivo, pero no es una cuestión central y podría desarrollarse espontáneamente un uso en este sentido. Y no creo puedan objetarse el resto de las decisiones referidas a las demás instituciones.

Respecto de las lenguas, me parece adecuado haber garantizado que cooficialidad no sea preferencia y aclarado que no existe un deber general, pero individualizado, de aprender catalán bajo la amenaza de sanciones en vez de un mandato de promover el uso de esta lengua en la función pública y la enseñanza. Pero el asunto de las lenguas vehiculares en la educación — según he razonado antes - me suscita bastante dudas y no sé hasta qué punto supone o no un drástico cambio del modelo, como parecen propugnar las sentencias del Tribunal Supremo dictadas en diálogo con las STC 31/2010. Es el tipo de decisión que no debe corresponder a un tribunal sino al legislador democrático, normalmente autonómico, y excepcionalmente básico.

Finalmente, me preocupa que sepamos extraer el intenso efecto de vinculación a la jurisprudencia constitucional, supra partes y erga omnes, para conseguir ajustar el ordenamiento jurídico del modo que la sentencia reclama, incluidos los Estatutos ya reformados y no impugnados.

\section{Luciano Parejo Alonso}

Lo más positivo es, con todas las críticas técnicas de que pueda ser objeto, la Sentencia misma en cuanto superación de las dificultades que amenazaban con determinar el autobloqueo del Tribunal Constitucional, aunque sea gracias al mantenimiento de la visión de la construcción del Estado autonómico solo como proceso y proceso, además, abierto indefinidamente a un curso sin límites constitucionales claros (salvo quizás el de la puesta en cuestión nominal de la unidad de la nación).

Lo más negativo es, paradójicamente, la persistencia en la aludida visión, pues siquiera sea por la dificultad de encaje limpio del Estatuto en la Constitución que el mismo contenido de la Sentencia pone de manifiesto habría debido — cuando menos y aún salvando la norma estatutaria en los términos en que lo ha hecho- advertir, cara al futuro, la llegada a los límites mismos del flexible modelo constitucional. Dicho de otra forma: habría debido plantearse la continuación del proceso conforme a las coordenadas en que hasta ese momento había venido desarrollándose.

Ambos aspectos no son, en definitiva, más que las dos caras de una misma moneda, sin que quepa tampoco descartar que la Sentencia pueda producir, a pesar de lo dicho y, 
por tanto, de no despejar la incertidumbre que rodea el llamado proceso autonómico, el efecto de desvelar la impractibilidad de toda evolución meramente continuista del mismo. De ser así, éste se habría conseguido en todo caso a un alto coste técnico-jurídico por la tensión al límite de ruptura de la técnica de la interpretación conforme y consiguiente colocación del Tribunal al borde mismo de los confines de su potestad jurisdiccional. El balance no es alentador ni en sede estrictamente constitucional, ni en la estatutaria: desfiguración de previsiones constitucionales bajo la veste de operación en el margen proporcionado por su flexibilidad, con minusvaloración, si no prescindencia, de la dirección efectiva por la norma fundamental de la continuación, en sede infraconstitucional, de la organización del Estado (dirección justamente precisada de construcción en sede interpretativa); pero desfiguración también de la norma estatutaria por su validación en sede de control, dada la imposibilidad de que su tejido prescriptivo pueda ser, sin más, enteramente reconducible al aprobado por el procedimiento establecido a tal fin tras su fragmentación y la transformación catalítica de los fragmentos por la interpretación conforme para lograr el efecto validador.

8. ¿Nos puede dar alguna opinión sobre los puntos que Vd. desee glosar de todos o de algunos de los votos particulares?

\section{Raúl Canosa Usera}

Los votos particulares, salvo el del magistrado Eugenio Gay, deseaban una sentencia más dura con el Estatuto. Achacan a la mayoría actuar como legislador positivo abusando de las interpretaciones conforme. A su juicio, el rechazo debería haber sido mucho más enérgico porque en realidad con el Estatuto se puso en marcha un espurio poder de reforma constitucional, es decir, se intentaba alterar radicalmente el entendimiento del orden establecido en la Constitución. En sus posiciones, los votos particulares son de una pétrea coherencia y habrían concluido, de haber integrado la mayoría, en una mutilación completa del Estatuto. Se hubieran zanjado así muchos problemas que con la sentencia subsisten, porque habrá que ver cómo se concreta la vinculación a todos los poderes públicos —el legislador catalán en especial— a la doctrina del TC (arts. 38.1 y 87.1 LOTC). La mayoría prefirió los riesgos de abrir una larga senda de conflictos que, cuando sean resueltos, irán decantando las consecuencias de la STC 31/2010.

El TC partió, como era su obligación, de la presunción de constitucionalidad del Estatuto, presunción, si cabe, reforzada por el refrendo que recibió del cuerpo electoral de Cataluña. Cierto es que la técnica de la interpretación conforme, consecuencia de tal presunción, ha sido llevada a su límites en la STC 31/2010, y esto es lo que con tanta acritud denuncian casi todos los votos particulares (denuncia reiterada, por lo demás, en varias sentencias anteriores durante los últimos años). Reclaman, pues, una actitud más beligerante frente al legislador estatuyente. 


\section{FranCESC DE CARreras SERra}

Ya he dicho con anterioridad, en respuesta al epígrafe 7 de este cuestionario, que valoraba extraordinariamente la coincidencia de fondo entre el contenido de la sentencia y tres de los votos particulares, debido a la autoridad y legitimidad que tal coincidencia aportaba a la resolución. Sin embargo, no pueden obviarse las discrepancias que se reflejan en cuanto al fallo, especialmente por el distinto alcance que se otorga a los límites de las sentencias interpretativas. En este punto, la lectura de estos votos particulares tiene un particular interés y no les falta razón desde un punto de vista teórico, especialmente en lo que respecta a su doctrina sobre la función del Tribunal Constitucional y al valor jurídico de sus sentencias. En realidad, son un importante complemento del texto aprobado por la mayoría y comparto, como puede comprobarse con la lectura de algunas respuestas anteriores, sus premisas básicas, es decir, sus presupuestos de partida. Sin embargo, me reafirmo en la valoración positiva de la sentencia por las razones expresadas en el epígrafe 7.

No obstante, no querría dejar pasar la ocasión sin destacar la honda impresión que me ha causado la solidez jurídica de los votos discrepantes de los magistrados Vicente Conde y Javier Delgado. Permítanme que reproduzca parcialmente el encabezamiento de sus votos discrepantes al objeto de apreciar el rigor de sus posiciones.

Comienza así don Vicente Conde: «Creo que no se comprendería la actitud personal que este voto trata de reflejar sin una previa explicación de cómo entiendo el cometido del Tribunal Constitucional y, en relación con él, mi propia función como magistrado del mismo. Siempre he creído que el Tribunal Constitucional es estrictamente un Tribunal de Derecho, y en tal sentido me ha producido siempre un especial rechazo intelectual la tesis de los que aceptan desde instancias doctrinales ajenas al Tribunal, paladina o vergonzantemente, su caracterización como institución jurídico-política. Mi fe en la efectividad de la Constitución como norma me lleva directamente a la convicción de que la garantía última de tal efectividad tiene su clave precisamente en el Tribunal Constitucional, siempre que éste se conciba como un auténtico Tribunal; esto es, como Tribunal de Derecho. Y para serlo, creo que es elemento constitutivo de su esencia institucional el estar «sometido sólo a la Constitución y a la presente Ley Orgánica» (art. 1 de la LOTC); pero, por supuesto, sometido a ellas. Ese rasgo de esencial sumisión del Tribunal Constitucional a la Constitución y a la LOTC no se atenúa por la caracterización de aquél como «interprete supremo de la Constitución» (art. 1 LOTC), que, a mi juicio, en modo alguno atribuye al Tribunal un espacio de disponibilidad de la norma sometida a su enjuiciamiento, que llegue al punto de permitirle reconfigurarla, sino que simplemente marca la jerarquía de sus juicios respecto del resto de los demás posibles intérpretes de la Constitución; pero en todo caso sin introducir en su relación de sumisión a la Constitución ningún factor de laxitud».

A su vez, don Javier Delgado inicia su voto de la manera siguiente: «Ante todo, dicho sea con el máximo respeto a mis compañeros, he de subrayar que mi discrepancia respecto a la sentencia dictada en estos autos es radical, en cuanto arranca de dos raíces: por una parte, la naturaleza de este Tribunal, al que la Constitución atribuye una muy bien perfilada función de la que derivan claros límites, que en esta sentencia se desbordan ampliamente, y, por otra, la naturaleza de los Estatutos de Autonomía, a los que la Consti- 
tución asigna un contenido que, obviamente, implica unos límites, que la resolución de la que discrepo no ha atendido en todas sus relevantes consecuencias. En la primera de las indicadas líneas - naturaleza del Tribunal Constitucional - he de señalar que esta Sentencia, en buena medida, se aparta de la función estrictamente jurisdiccional que le es propia para, en lo que denomina interpretaciones, crear unas normas nuevas invadiendo el campo funcional del legislador: salva así de la declaración de inconstitucionalidad muchos preceptos, pero esto se logra atribuyéndoles un sentido diferente, a veces contrario al que su texto expresa e incluso en ocasiones se les despoja de toda virtualidad jurídica, reduciéndolos a meros propósitos o a simples pretensiones o sugerencias y, en algunos casos, a descripciones de la doctrina del Tribunal Constitucional, con todo lo cual viene a dar una redacción nueva a no pocos aspectos del Estatuto».

El Derecho es una ciencia que utiliza la razón para obtener las finalidades que las normas jurídicas prescriben. No es un saber analítico sino dialéctico, no está basado en demostraciones sino en argumentaciones. La lectura conjunta del cuerpo de la STC 31/2010 y de los votos particulares, pone de manifiesto esta naturaleza dialógica del Derecho. Así pues, sigue siendo razonable lo que dijo Kelsen en su Teoría Pura del Derecho: «Todos los métodos interpretativos desarrollados hasta ahora llevan siempre a un resultado posible y nunca a un único resultado correcto».

\section{MARC CARriLlo LÓPEZ}

Los votos particulares de los magistrados Conde Martín de Hijas, Delgado Barrio, Rodríguez-Zapata Pérez y Rodríguez Arribas muestran su desacuerdo con la mayoría del Tribunal, en aspectos que alcanzan a un amplio contenido del Estatuto. De hecho, y con matices según su autor, a todos los Títulos en los que se divide el texto: el preámbulo, el título preliminar, los derechos estatutarios, los derechos lingüísticos, la Administración de Justicia, las competencias, etc. De acuerdo con los argumentos expuestos en las respuestas a las preguntas anteriores, mi discrepancia con la posición sostenida por dichos votos particulares es plena.

No obstante, quizás merece subrayarse el punto de partida del primero de los magistrados citados, compartido también por el segundo, por el que sostienen que su posición nace de la concepción del Tribunal Constitucional como «un Tribunal estrictamente de Derecho» sometido a la Constitución y a la LOTC. Merece, digo, resaltarse porque no deja de sorprender que con este presupuesto previo que comparto, ambos — no obstante- avalasen la insostenible recusación del magistrado Pérez Tremps. Como también no deja de causar perplejidad que no tuviesen en cuenta que entre los elementos que justifican la idoneidad para el cargo de un magistrado constitucional, es el conjunto de su obra académica y profesional realizada, como era el caso, antes de acceder a este alto cargo del Estado.

\section{Javier Corcuera Atienza}

Permítaseme una respuesta breve y de conjunto, que completa lo que acabo de decir. En primer lugar, suscribo la opinión de Francesc de Carreras, que señala que las di- 
vergencias entre los magistrados han sido menores de lo que parece. En la mayor parte de los casos, los desacuerdos no están en el fondo, sino en la apreciación en los votos particulares de redacciones inconstitucionales donde la sentencia se esfuerza por definir un sentido constitucional de entre los posibles. He expuesto las razones que me hacen apoyar una sentencia que, no silenciando los aspectos inconstitucionales, ha optado por minimizar su efecto en el texto del Estatut. Es posible (y necesaria) la conjunción entre las posturas de unos y otros: dependerá de la voluntad de quienes pueden instar el control de legalidad y constitucionalidad de las normas reglamentarias y de las leyes que afecten a materias mencionadas en la sentencia.

\section{JAVIER GARCÍA RoCA}

Los Votos disidentes manifiestan global y duramente su disconformidad con esta sentencia interpretativa de rechazo. Una técnica seguida para adaptar el Estatuto a la Constitución. Me centraré en este punto. Consideran que el Tribunal ha invadido el campo del legislador, construyendo, en muchos casos, preceptos nuevos y alejados de la voluntad original del legislador. Critican la falta de claridad y la inseguridad jurídica que provoca esta forma de actuar. Censuran que el Estatut no es sino una reforma encubierta de la Constitución. Y consideran que la parte dispositiva de la sentencia no recoge todas las interpretaciones correctoras que realizan los fundamentos jurídicos ni se advierte en la motivación las razones para seguir una u otra solución; una crítica que puede ser compartida pero sólo en su segunda parte, pues siempre hemos tenido en nuestra jurisdicción constitucional interpretaciones conforme de ambos tipos. Asimismo discrepan del contenido reconocido a los Estatutos, pues no admiten otro que el expresamente previsto en la Constitución, bien en el artículo 147, bien en otros lugares del texto, reconociendo únicamente, como ocurre con las demás leyes orgánicas, la inclusión de materias conexas para una mejor comprensión de la regulación. Cualquier otro contenido debería haber sido, según ellos, considerado inconstitucional y nulo. Una interpretación originalista, desconectada del carácter evolutivo de la moderna interpretación constitucional en toda Europa y que no puedo compartir pues resulta inapropiada para interpretar una Constitución tan abierta.

De haberse convertido las tesis tan radicales de la minoría en mayoría la generalidad del Estatuto habría sido declarada inconstitucional y hoy estaríamos en una situación insostenible: un verdadero impasse. Cabe formularse a la vista de la inflexibilidad de este conjunto de argumentaciones, tres interrogantes básicos sobre la comprensión del conflicto que los Votos disidentes evidencian. Primero, qué margen de deferencia hacia las Cortes Generales, el Parlamento de Cataluña y el cuerpo electoral respetan los Magistrados discrepantes, en otras palabras, qué entendimiento poseen de la fuerte presunción democrática de constitucionalidad de las leyes, y, con mayor razón, ante una fuente del Derecho aprobada por una base decisional tan amplia como son dos asambleas representativas y un ejercicio directo de la participación política. Un cierto self-restraint o autocontrol frente al legislador democrático es siempre una buena recomendación para cualquier juez constitucional y es prudente en caso de duda. Desvirtuar una presunción iuris tantum de constitucionalidad de la ley requiere una fuerte carga argumental más allá de cualquier duda razonable. Pero los Magistrados disidentes no parecen albergar dudas. 
Segundo, dónde queda el no menos constitucional principio de seguridad jurídica y de conservación de los actos emanados tras cuatro años de aplicación de un Estatuto en numerosas situaciones de hecho y de Derecho. Es precisamente ese horror al vacío, la evitación del daño, el que determina el habitual entendimiento doctrinal de la nulidad como consecuencia siempre excepcional de la inconstitucionalidad y no la regla general, como los Votos parecen creer, y que, por consiguiente, si se me permite la imagen, sea normalmente menester zurcir las leyes como hacían con paciencia nuestras madres con los calcetines viejos antes de desecharlos.

Tercero, qué alternativa doctrinal ofrecen a la técnica de las interpretaciones conforme mediante las sentencias interpretativas de rechazo (las manipulativas o de recomendación legislativa entre ellas). Una herramienta muy usada por la Corte Constitucional italiana, bien estudiada por la doctrina científica tanto allí como en España, y que nuestro Tribunal Constitucional trasplantó en los primeros años a nuestro Derecho y lleva desde entonces utilizando ininterrumpidamente, especialmente, en todas las controversias competenciales. De sobra sé que han sido objeto de críticas doctrinales en ambos países, pero también de defensas harto razonadas que los Votos no reproducen al no meterse en demasiadas honduras. Mas no se trataba de escribir artículos científicos ni de realizar experimentos innovadores, hard cases make bad law, la cuestión es otra. ¿Sinceramente se cree que era ésta, por su complejidad, la ocasión de comenzar de nuevo desde cero y hacer tabla rasa de tres décadas de jurisprudencia y experiencias constitucionales? Con toda probabilidad no sería difícil probar que los mismos Magistrados que censuraron en este caso la técnica de las sentencias interpretativas la habían usado en bastantes ocasiones previas en otras sentencias constitucionales sin formular reproche alguno. ¿Qué ha ocurrido?

\section{Luciano Parejo Alonso}

La lectura de los votos particulares deja cierta desazón provocada sin duda por el hecho de que las preocupaciones que expresan no se hayan manifestado, siquiera sea con la intensidad y la contundencia con la que ahora lo hacen, sino en relación con (no necesariamente a propósito de) el Estatuto de Cataluña. Pero, no pareciéndome posible hacer aquí un análisis que les haga debida justicia, me limito a señalar que, siendo explicable el emitido por el Magistrado Eugeni Gay Montalvo, el que me parece más estimable técnicamente y con el que, en todo caso, mayor coincidencia, tengo (desde luego por lo que hace al planteamiento general, aunque no así necesariamente en sus objeciones concretas), es el formulado por el Magistrado Vicente Conde Martín de Hijas.

Las razones de esta estimación y coincidencia son las siguientes:

a. La reafirmación que hace de la normatividad de la Constitución y la sumisión a ella del Tribunal Constitucional en tanto que Tribunal de Derecho, incluso y precisamente en su caracterización como intérprete supremo de la norma fundamental y cuando la norma sometida a su control es un Estatuto de Autonomía. Aunque echo en falta, a este último respecto, una referencia directa a la razón que debe ser determinante: la importancia decisiva de los Estatutos de Autonomía para el acabado de la dimensión territorial de la organización del Estado constituido. 
b. Su análisis ajustado de los límites de la técnica de la interpretación conforme y el riesgo de extralimitación de la función jurisdiccional que el exceso de tensión en su empleo comporta. Y las dos conclusiones que extrae: la técnica sirve a la «conservación», que no a la «reconversión», de la norma enjuiciada y debe preservar la inteligibilidad del resultado para la ciudadanía (mejor sería decir, añado yo, la certeza normativa y, por tanto, la seguridad jurídica), lo que excluye, en todo caso, interpretaciones vinculantes no llevadas al fallo (cosa que se hace en la Sentencia). Y el apunte que, de forma coherente en el previo voto particular a la STC 247/2007, realiza de la necesidad de respetar la función constitucional de los Estatutos de Autonomía que resulta del artículo $147 \mathrm{CE}$, por más que aquí se echa en falta un desarrollo mayor de cual sea esa función constitucional y el marco constitucional organizativo en el que, en todo caso, debe desplegarse

$* * *$

Title: Spanish Constitutional Court Jugment 31/2010, 28TH JunE

ABSTRACT: This academic survey, answered by Public Law Professors, focuses on the Decision 31/2010 of the Constitutional Court, on 28th juny, about a group of demands against the new "Estatuto de Cataluña, the foundation norm of Cataluña, approved by the Ley Orgánica 6/2006, on 19th july. In this survey can be found questions relative to the constitutional court decision content - the validity of the preamble, the official languages, organs and institutions in Cataluña and in the Central State, competences and financing - as well as relative to the dissent opinions and to the context in which this decision has been taken.

RESUMEN: Esta encuesta, a la que responden especialistas de la disciplina se centra en la Sentencia 31/2010, de 28 de junio, emitida por el Tribunal Constitucional sobre el conjunto de recursos presentados contra el nuevo Estatuto de Cataluña, aprobado por Ley Orgánica 6/2006, de 19 de julio. En ella se plantean diferentes cuestiones relativas al contenido de la sentencia —el valor del preámbulo del Estatuto, la cooficialidad lingüística, órganos e instituciones catalanas y estatales, distribución de competencias y financiación-, así como cuestiones relativas a los votos particulares y al contexto en el que se ba dictado esta sentencia.

KeYwords: Constitution. Foundation norms of the «Comunidades Autónomas» Constitutional Court Decision $31 / 2010$.

Palabras Clave: Constitución. Estatutos de Autonomía. STC 31/2010.

UNED. Teoría y Realidad Constitucional, núm. 27, 2010, pp. 9-130. 
01ok 04/05/2011 8:34 Página 130

(8) 